\title{
FORMACÎAO EM SAÚDE: OLHARES SOBRE PRÁTICAS EDUCATIVAS
}

Camilo Darsie

Betina Hillesheim

Vera Elenei da Costa Somavilla

[organizadores] 


\section{FORMACĨO EN SAOUDE: OLHARES SOBRE PRÁTICAS EDUCATIVAS}

Camilo Darsie

Betina Hillesheim

Vera Elenei da Costa Somavilla [organizadores] 


\section{CONSELHO EDITORIAL}

Prof. Dr. Adilson Tadeu Basquerote

Silva

UNIDAVI/SC

http://lattes.cnpq.br/8318350738705473

Profa. Msc. Jesica Wendy Beltrán

UFCE- Colômbia

http://lattes.cnpq.br/0048679279914457

Profa. Dra Fabiane dos Santos Ramos UFSM- Santa Maria/RS

http://lattes.cnpq.br/0003382878348789

Dr. João Riél Manuel Nunes Vieira de Oliveira Brito

UAL - Lisboa- Portugal.

http://lattes.cnpq.br/1347367542944960

Profa. Dra. Alessandra Regina Müller Germani

UFFS- Passo Fundo/RS

http://lattes.cnpq.br/7956662371295912

Prof. Dr. Everton Bandeira Martins

UFFS - Chapecó/SC

http://lattes.cnpq.br/9818548065077031

Prof. Dr. Erick Kader Callegaro Corrêa UFN- Santa Maria/RS

http://lattes.cnpq.br/2363988112549627

Prof. Dr. Pedro Henrique Witchs

UFES - Vitória/ES

http://lattes.cnpq.br/3913436849859138

Prof. Dr.Thiago Ribeiro Rafagnin UFOB

http://lattes.cnpq.br/3377502960363268
Prof. Dr. Mateus Henrique Köhler

UFSM- Santa Maria/RS

http://lattes.cnpq.br/5754140057757003

Profa. Dra. Liziany Müller Medeiros

UFSM- Santa Maria/RS

http://lattes.cnpq.br/1486004582806497

Prof. Dr. Camilo Darsie de Souza

UNISC- Santa Cruz do Sul/RS

http://lattes.cnpq.br/4407126331414

Prof. Dr. Dioni Paulo Pastorio

UFRGS - Porto Alegre/RS

http://lattes.cnpq.br/7823646075456872

Prof. Dr. Leonardo Bigolin Jantsch

UFSM- Palmeira das Missões/RS

http://lattes.cnpq.br/0639803965762459

Prof. Dr. Leandro Antônio dos Santos

UFU- Uberlândia/MG

http://lattes.cnpq.br/4649031713685124

Dr. Rafael Nogueira Furtado

UFJF- Juiz de Fora/MG

http://lattes.cnpq.br/9761786872182217

Profa. Dra. Angelita Zimmermann

UFSM- Santa Maria/RS

http://lattes.cnpq.br/7548796037921237

Profa. Dra. Francielle Benini Agne

Tybusch

UFN - Santa Maria/RS

http://lattes.cnpq.br/4400702817251869

Copyright (C) Arco Editora, alguns direitos reservados.

Copyright do texto (c) 2022 os autores e as autoras.

Copyright da edição (c) 2022 Arco Editora. 
Diagramação e Projeto Gráfico : Gabriel Eldereti Machado

imagem capa: $w w w$. pixabay.com

Revisão: dos/as autores/as.

Dados Internacionais de Catalogação na Publicação (CIP) (Câmara Brasileira do Livro, SP, Brasil)

Formação em saúde [livro eletrônico] : olhares sobre práticas educativas / Camilo Darsie, Betina Hillesheim, Vera Elenei da Costa Somavilla [organizadores]. -- 1. ed.

Santa Maria, RS : Arco Editores, 2022. PDF

Vários autores.

ISBN 978-65-89949-43-5

1. Doenças - Prevenção 2. Educação em saúde 3. Medicina preventiva 4. Práticas educacionais

5. Promoção da saúde I. Darsie, Camilo.

II. Hillesheim, Betina. III. Somavilla, Vera Elenei da Costa.

21-89937

CDD-610. 7

NLM-WA 590

Índices para catálogo sistemático:

1. Educação em saúde : Doenças : Prevenção :

Promoção da saúde 610.7

Maria Alice Ferreira - Bibliotecária - CRB-8/7964

\section{dol 10.48209/978-65-SAUDE-43-S}

O padrão linguístico-gramatical, bem como o sistema de citações e referências bibliográficas são prerrogativas de cada autor. Da mesma maneira, o conteúdo e teor de cada capítulo é de inteira e exclusiva responsabilidade de seu respectivo autor. 


\section{APRESENTAÇÃO}

Camilo Darsie

Betina Hillesheim

Vera Elenei da Costa Somavilla

Um movimento pedagógico que emergiu no contexto da formação em saúde, mais precisamente, na disciplina de Educação e Saúde do curso de Medicina da Universidade de Santa Cruz do Sul, localizada no Vale do Rio Pardo, no Rio Grande do Sul. Assim pode ser definido o trabalho que originou os textos que compõem esta coletânea.

A ideia inicial consistia na mobilização de estudantes em relação aos princípios que envolvem as políticas públicas de saúde brasileiras, especialmente aquelas que se relacionam à educação no contexto da saúde. A importância da abordagem de temáticas relativas ao campo da educação tem sido comentada e fortalecida por meio de regulamentação nacional e currículos de formação que privilegiam a formação profissional em saúde por meio de uma perspectiva que articula saberes técnicos a demandas sociais coletivas de diferentes localidades/ realidades em que os futuros profissionais irão atuar. Entende-se que

no movimento constante em defesa do Sistema Único de Saúde (SUS) como projeto de um sistema universal, público, equânime, integral e democrático, encontra-se a necessidade de se buscar uma concepção da relação educação e saúde que se configura como resultado da ação política de indivíduos e da coletividade, com base no entendimento da saúde e da educação em suas múltiplas dimensões: social, ética, política, cultural e científica (MOROSINI, FONSECA e PEREIRA, 2009).

Porém, conforme a atividade foi sendo desenvolvida, revelou-se uma grande oportunidade didática relacionada à pesquisa e à produção de textos capazes de atingirem outros estudantes e profissionais interessados pela temática. 
Ainda mais, expandiu-se para outras universidades e cursos - como Psicologia e Enfermagem - cujas reflexões ainda estão em fase de elaboração e logo virão!

Assim, destacamos que a obra apresenta produções feitas por estudantes, em fase de formação profissional, que por meio de seus olhares acerca das possibilidades de aproximação entre os campos da educação e da saúde, desempenharam pesquisas, discussões e a elaboração de seus argumentos. Desejamos que a leitura dos capítulos seja de grande utilidade, especialmente no que se refere à multiplicação de ações como a que apresentamos aqui.

MOROSINI, M.V.; FONSECA, A. F.; PEREIRA, I. B. Educação em Saúde, Dicionário da Educação Profissional em Saúde, Fundação Oswaldo Cruz. Escola Politécnica de Saúde Joaquim Venâncio. Manguinhos, Rio de Janeiro, 2009. 
Cristianne Maria Famer Rocha

A formação em Saúde, no Brasil, nas últimas décadas, tem ensejado inúmeras experiências e reflexões que merecem nossa atenção. Se pensarmos, historicamente, como foi instituído nosso atual sistema de saúde - único, universal, integral, equitativo, participativo, descentralizado, regionalizado e hierarquizado -, em comparação com o vivido e realizado ao longo dos últimos cinco séculos, desde a chegada (ou invasão?) dos portugueses em território nacional, nos damos conta que a inovação representada pela instauração de um Sistema Único de Saúde (SUS), em um país de dimensões continentais, com culturas e práticas tão diversas, em suas diferentes regiões, estados e municípios, não somente é um enorme feito, mas também motivo de orgulho para todos nós, brasileiros e brasileiras, que temos um dos mais complexos e completos sistemas universais públicos de saúde no mundo atual.

Da mesma forma, no campo da formação (técnica e profissional), são inúmeros os motivos para nos orgulhar: desde iniciativas mais tímidas e locais, até políticas públicas de âmbito nacional que visam fortalecer os princípios e diretrizes do SUS.

Com a intenção de nos permitir conhecer algumas dessas práticas educativas (atuais e históricas), no âmbito da formação em saúde, os textos que compõem esta publicação trazem uma visão ampliada sobre a temática, demonstrando um compromisso com a diversidade, com a atualidade e com a necessária reflexão a respeito de como estamos formando nossos trabalhadores e profissionais para o cuidado em saúde.

A publicação está organizada em dez capítulos, produzidos em sua maioria por acadêmicos do Curso de Medicina da Universidade de Santa Cruz do Sul 
(UNISC) - mas não somente - e traz interessantes abordagens a respeito de experiências vividas ao longo da formação dos próprios autores/as. Entre reflexões, relatos, análises e vivências, os textos nos permitem vislumbrar algumas das temáticas tratadas durante a formação dos próprios autores/as, em intersecção com os espaços sociais e institucionais vividos.

A pluralidade das temáticas abordadas também nos permite pensar no quão diverso está sendo (e deverá ser, sempre mais) a formação em saúde, com o incentivo à ampliação de temáticas e abordagens que nos permitam ver e viver a complexidade da atenção à saúde no Brasil. Afinal, ampliar o olhar para populações que vivem em situação de vulnerabilidade (como as populações que vivem em situação de rua), assim como para enfermidades negligenciadas (como a sífilis, por exemplo) ou para estratégias midiáticas (como as utilizadas nas redes sociais) nos obriga a atualizar o olhar e o compromisso com a inclusão de populações, práticas e temas nem sempre bem vistos ou bem vindos no espaço acadêmico, em nossos currículos, pesquisas e produções científicas.

O ineditismo da produção coletiva de graduandos, ou seja, de pessoas em formação, também é uma qualidade desse livro. Afinal, são cada vez mais escassas as oportunidades de publicação no Brasil. Ainda que tenhamos ampliado o número de revistas e artigos científicos nas últimas duas décadas, a falta de incentivos financeiros por parte dos últimos dois governos federais, sobretudo com a aprovação da Emenda Constitucional 95, em 2016, também conhecida como a "Emenda Constitucional do Teto dos Gastos Públicos" (ou, mais corriqueiramente, a "PEC da Morte"), com o congelamento das despesas e investimentos em todas as áreas, tem inviabilizado a produção científica brasileira, nos colocando à míngua e à margem da produção internacional. Tal desmantelamento atinge todos nós e, em particular, os jovens autores e cientistas. Nesse sentido, saúdo este livro, seus organizadores/as e autores/as por terem a coragem de enfrentar a escassez de oportunidades do mercado editorial e inovarem com a produção coletiva. 
Por fim, gostaria de indicar que as reflexões e experiências aqui trazidas, no campo da formação em Saúde, poderão representar uma oportunidade de aprendizado com o que tem sido feito na UNISC, mas principalmente nos convocar a pensar sobre o que poderemos fazer para resistir e inventar outros modos de produção científica, que sejam menos competitivos e mais indutivos à prática solidária, coletiva, inventiva, comprometida e responsável para com a melhoria dos nossos sistemas de Saúde e de Educação no Brasil. 


\section{SUMÁRIO}

\section{CAPÍTULO 1}

CAMPANHAS BRASILEIRAS DE PREVENÇÃO DE DOENÇAS (2019-2021)

E OS SEUS EFEITOS EDUCATIVOS

doi: 10.48209/978-65-SAUDE-43-1

\section{CAPÍTULO 2}

IFMSA BRASIL UNISC: EXPERIÊNCIAS DE EDUCAÇÃO EM SAÚDE VIVIDAS POR ESTUDANTES DE MEDICINA QUE FAZEM A DIFERENÇA..27

doi: 10.48209/978-65-SAUDE-43-2

\section{CAPÍTULO 3}

POLÍTICA NACIONAL DE EDUCAÇÃo PERMANENTE EM SAÚDE: UM PANORAMA A PARTIR DE OLHARES UNIVERSITÁRIOS

doi: 10.48209/978-65-SAUDE-43-3

\section{CAPÍTULO 4}

HIV E AIDS: EDUCAÇÃO EM SAÚDE A SERVIÇO DA QUALIDADE DE VIDA

doi: 10.48209/978-65-SAUDE-43-4

\section{CAPÍTULO 5}

DETERMINANTES SOCIAIS E A IMPORTÂNCIA DA EDUCAÇÃO EM SAÚDE NA PREVENÇÃO DA SÍFILIS CONGÊNITA.

doi: 10.48209/978-65-SAUDE-43-5

\section{CAPÍtULOO 6}

SAÚDE DA POPULAÇÃO EM SITUAÇÃO DE RUA E O CONTEXTO PANDÊMICO 


\section{CAPÍTULO 7}

PRÁTICAS DE EDUCAÇÃO PARA SAÚDE NO MEIO RURAL: UMA ANÁLISE DO PROJETO "VIDA E SAÚDE NO CAMPO: TECNOLOGIAS EDUCATIVAS DESPERTANDO CONSCIÊNCIA".

doi: 10.48209/978-65-SAUDE-43-7

\section{CAPÍTULO 8}

BREVE ANÁLISE DO PROJETO DE EDUCAÇÃO POPULAR EM SAÚDE LGBT NOS POSTOS DE SAÚDE EM GOIÂNIA

doi: 10.48209/978-65-SAUDE-43-8

\section{CAPÍTULO 9}

YOUTUBE E EDUCAÇÃO EM SAÚDE: UTILIZAÇÃO DO CANAL DRUGSLAB COMO UMA AÇÃO DE EDUCAÇÃO EM SAÚDE VOLTADA PARA ADOLESCENTES.

doi: 10.48209/978-65-SAUDE-43-9

\section{CAPÍTULO 10}

SEX EDUCATION: IMPORTÂNCIA DA MÍDIA NA EDUCAÇÃO EM SAÚDE PARA SEXUALIDADE EM ADOLESCENTES .114

doi: 10.48209/978-65-SAUDE-43-0

SOBRE OS ORGANIZADORES 

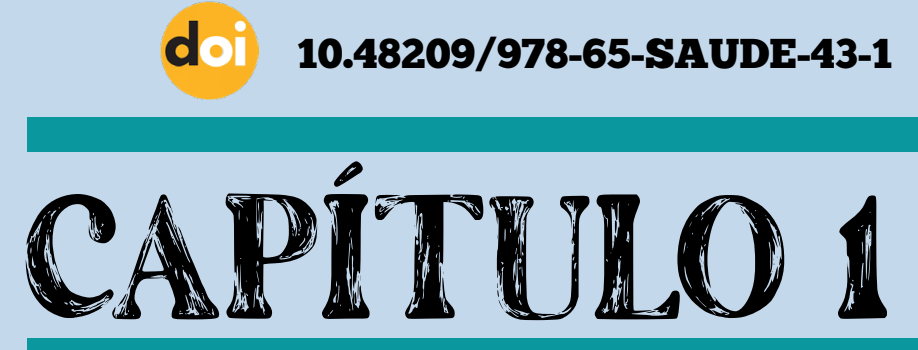

\section{CAMPANHAS BRASILEIRAS DE PREVENÇÃO DE DOENÇAS (2019-2021) E OS SEUS EFEITOS EDUCATIVOS}

Tiago Jairo Colling Martina Silveira Raineski Felipe Bernardon 


\section{INTRODUÇÃO}

Prevenir é um termo cujo significado encontra-se em constante modificação, evoluindo de conceitos europeus centrados no ato de "antecipar" ou de "evitar que algo ocorra" até se inserir no plano prático da saúde coletiva. No contexto da medicina preventiva da década de 1970, a prevenção em saúde foi definida como o conjunto de ações que evitam a ocorrência e/ou a progressão de uma doença (BLOOM et al; STARFIELD, 2008).

Essa ideia foi incorporada às bases epidemiológicas contemporâneas, contribuindo para o reconhecimento do termo pelo Ministério da Saúde (MS), que o interpretou como o conjunto de medidas que diminuem as taxas de morbidade e mortalidade na população (MINISTÉRIO DA SAÚDE, 2013). Uma das estratégias de prevenção de doenças do país é a Educação em Saúde (ES), que é preconizada pelo MS como uma maneira de formação e de desenvolvimento da consciência crítica do cidadão com o objetivo de encontrar soluções coletivas dos problemas vivenciados pela sociedade (FUNASA, 2007).

Posto isso, cartazes utilizados nas unidades de saúde, que são o alvo de estudo deste trabalho, são ferramentas de ES, pois fazem circular informações relevantes acerca da prevenção de doenças, das vacinas, das pesquisas, da ajuda humanitária etc.. Isso leva ao público brasileiro conhecimentos que ajudam a potencializar a qualidade de vida de sujeitos e comunidades. Para Rossi et al. (2012), essas ferramentas de ES devem ser, cada vez mais, ampliadas e aperfeiçoadas, por promoverem reflexões e por gerarem bons resultados frente aos problemas de saúde. Vale destacar, ainda, que as campanhas de saúde operam de modo a educar as populações, já que são estratégias de investimento na vida por meio da produção de sujeitos reflexivos (DARSIE, HILLESHEIM, WEBER, 2017).

Portanto, para a realização deste estudo, foi feita a análise de cartazes disponíveis para a utilização em Unidades de Saúde nacionais, sobretudo as pertencentes ao Sistema Único de Saúde (SUS). O objetivo é discutir os efeitos educativos das campanhas de prevenção de doenças do MS do Brasil. 


\section{METODOLOGIA}

Estudo de caráter exploratório, por meio de abordagem qualitativa, a fim de encontrar informações importantes sobre educação em saúde em campanhas governamentais a respeito de prevenção de doenças. Essas campanhas objetivam educar a população para que melhorem o seu estado e as suas condições de saúde. Para a realização do estudo, foram pesquisados, dentro do portal do MS - https://www.gov.br/saude/pt-br - cartazes que abordam a prevenção de doenças a partir de vários aspectos: vacinação, doenças e estilos de vida. Foram utilizados 42 cartazes sem critério de exclusão e o recorte temporal do material utilizado se dá entre o ano de 2019 e agosto de 2021.

\section{ANÁLISE DE RESULTADOS}

A partir da análise dos 42 cartazes disponibilizados no portal do MS, observa-se que as campanhas de prevenção de doenças e de promoção da saúde, dos anos anteriores à 2019 foram apagadas pelos atuais gestores públicos. Por conta disso, o recorte do estudo compreende as campanhas de 2019 até agosto de 2021. Para uma melhor didática de estudo, os cartazes foram separados em categorias de acordo com seus conteúdos. As categorias selecionadas e o número de cartazes encontrados em cada ano podem ser vistas na tabela abaixo.

Tabela 1 - Categorias e anos de publicação

\begin{tabular}{|c|c|c|c|}
\hline & 2019 & 2020 & 2021 \\
\hline Outras Doenças & 4 & 4 & 9 \\
\hline Vacinas & 5 & 3 & 2 \\
\hline Pesquisa e Ajuda Humanitária & 0 & 1 & 3 \\
\hline Saúde da Criança e do Adolescente & 0 & 0 & 2 \\
\hline Saúde da Mulher e da Gestante & 0 & 2 & 1 \\
\hline IST & 3 & 2 & 0 \\
\hline Saúde do Homem & 0 & 1 & 0 \\
\hline
\end{tabular}


Foram analisados os seguintes temas dos cartazes na categoria de Doenças: hanseníase, tuberculose, malária, combate ao mosquito, coronavírus, leishmaniose e doença de Chagas. Na categoria Vacinas: gripe, Movimento Vacina Brasil, Hepatite, Sarampo e febre amarela. Na categoria Pesquisa e Ajuda Humanitária: doação de órgãos, doação de sangue e Precov. Na categoria Saúde da Criança e do Adolescente: obesidade infantil e gravidez na adolescência; na categoria Saúde da Mulher da Gestante: amamentação e Outubro Rosa. Na categoria Infecções Sexualmente Transmissíveis (ISTs): HIV, ISTs e Aids e na categoria Saúde do Homem: saúde do homem. Esses cartazes são distribuídos nas Unidades de Saúde do Brasil, fazendo circular a narrativa do Ministério da Saúde sobre a Prevenção de Doenças.

\section{Outras Doenças}

No Brasil, a situação epidemiológica das doenças modifica-se ao longo dos anos e as políticas de saúde são alteradas a fim de adequar o planejamento em saúde aos eventos de maior interesse para a saúde pública. A utilização da epidemiologia como ferramenta para o desenvolvimento de estratégias de prevenção de doenças no sistema de saúde consolidou-se nas últimas décadas, sendo que um dos marcos iniciais foi a fundação do Centro Nacional de Epidemiologia, em 1990 (BARRETO, 2002). A partir disso, a epidemiologia mostrou-se essencial para vigilância de doenças, análise da situação de saúde da população, procura dos problemas prioritários de saúde, elaboração de políticas de saúde, adequação dos serviços de saúde e avaliação do sistema de saúde (PAIM, 2003).

Em 2019, a Secretaria de Vigilância em Saúde considerou como doenças de maior relevância para o Sistema Único de Saúde (SUS) as arboviroses, como dengue, chikungunya, zika e febre amarela, por conta de seu alto potencial de disseminação; a malária e a hanseníase, em razão do aumento do número de casos; as zoonoses, em especial leishmaniose e influenza, devido à dificuldade do controle. As arboviroses, transmitidas através da picada de artrópodes hematófagos, foram consideradas como potencialmente epidêmicas, da mesma forma como a doença de chagas, a leishmaniose, e a influenza. Por outro lado, 
a hanseníase e a tuberculose foram consideradas relevantes no que se refere às condições crônicas provocadas por elas (MINISTÉRIO DA SAÚDE, 2019). Na mesma perspectiva, desde a chegada do SARS-CoV-2 ao país, a Covid-19 passou a ser considerada uma doença abordada no material do MS.

Diante da necessidade da criação de estratégias para evitar a ocorrência e a progressão das doenças de interesse para a saúde pública e levando em consideração as estatísticas reunidas pelos sistemas de informação em saúde, percebeu-se que os cartazes foram elaborados como parte da estratégia do MS para orientar e prevenir a população a respeito de doenças que representavam um problema de saúde pública. Isso pode ser observado, por exemplo, por meio de um cartaz direcionado à prevenção da Covid-19, que incentiva a população a desenvolver hábitos como distanciamento social, uso de máscaras e vacinação. Outro exemplo é um cartaz que aborda a doença de Chagas. Ele orienta sobre as formas de prevenção, modos de transmissão, e manifestação da doença em suas fases aguda e crônica. Além disso, ensina a fazer a higienização adequada dos alimentos e passa orientações às gestantes.

Os cartazes, através de informações sobre os perigos que envolvem diferentes doenças e sobre os modos como são transmitidas, se manifestam no organismo e, ainda, sobre como podem ser evitadas e tratadas, visam educar a população a respeito da relevância das doenças e das ações individuais para preveni-las.

\section{Vacinas}

Em 1973, foi criado, no Brasil, o Programa Nacional de Imunização, que fortaleceu a organização e a coordenação das ações de vacinação no país, estendendo o direito à vacina às crianças, aos adolescentes, aos adultos, aos idosos e, também, aos povos indígenas. Essas ações contribuíram para a situação da saúde da população brasileira, porque reduziram casos de adoecimento, a exemplo do vírus do sarampo e da rubéola (JUNIOR, 2013). 
A par da importância da imunização da população, nota-se, por meio dos cartazes analisados, a preocupação do MS com a vacinação da população brasileira, já que foram identificados, proporcionalmente, um bom número de materiais referentes ao tema. Destes, alguns se associam ao calendário vacinal, às orientações para as pessoas com comorbidades, à necessidade de estar com as vacinas em dia e, sobretudo, à importância da prevenção da doença.

Pelo Informe Técnico (2019) publicado pelo MS, no ano de 2019 foram distribuídas 63.753.500 doses de vacinas contra a gripe no Brasil (MINISTÉRIO DA SAÚDE, 2019). Embora esse número de doses seja expressivo, a necessidade de estímulo e acompanhamento das vacinas não deixa de ser um problema de saúde pública. Para Menezes et al. (2021), a meta de cobertura vacinal do PNI é de $90 \%$ da população-alvo - idosos, crianças e pessoas com comorbidades contra a gripe.

Portanto, observa-se que a imunização, especialmente contra a gripe, é uma preocupação do MS. Neste sentido, ao serem tomados os cartazes enquanto embasamento, observa-se que a distribuição de vacinas é apontada como a principal estratégia, especialmente quando associada à utilização do material midiático que auxilia para a educação dos sujeitos.

\section{Pesquisa e Ajuda Humanitária}

As iniciativas comunitárias são importantes para as políticas de promoção da saúde e prevenção de doenças. A mobilização da sociedade, em defesa da vida e do desenvolvimento humano, exige comprometimento, solidariedade, reflexão e problematização sobre a situação de saúde, assim como participação ativa de forma autônoma.

Entre as ações de ajuda humanitária na esfera da saúde, destacam-se a doação de órgãos e a doação de sangue. Segundo Bertasi et al. (2019), as doações cresceram significativamente nas últimas décadas, mas ainda não atingem os índices ideais, visto que a demanda por transplantes e transfusões de sangue 
ainda são superiores às ofertas propiciadas pelos doadores. No primeiro semestre de 2018 , o número total de solicitações para transplantes de órgãos ultrapassou 24 mil na lista de espera. Já para a doação de sangue, em 2016, o MS indicou como ideal o oferecimento de 5,7 milhões de bolsas de sangue, 2,2 milhões a mais do que a oferta real (BERTASI et al. 2019; MINISTÉRIO DA SAÚDE, 2016).

Também foram identificados cartazes para a divulgação da PrevCOV, a pesquisa aprovada pelo Ministério da Saúde para estudar a prevalência da Covid-19 no Brasil. A pesquisa apresenta-se como um elemento importante no fortalecimento das políticas de saúde, especialmente para evitar a ocorrência e a progressão da doença causada pelo vírus SARS-CoV-2, pois determina a magnitude da infecção, avalia as taxas de morbidade e mortalidade, e analisa o perfil dos participantes da pesquisa. Além disso, auxilia no planejamento em saúde, esse estudo corresponde a uma alternativa de participação social que contribui para a saúde pública, já que depende do comprometimento dos participantes da pesquisa para produzir informações acuradas.

É possível afirmar que a participação social é de extrema importância para a melhoria e para a manutenção da saúde da população. Nesse sentido, os cartazes que conscientizam os leitores sobre a participação em campanhas de doação incentivam a ajuda mútua e possibilitam o desenvolvimento de uma cultura, tanto participativa quanto saudável.

\section{Saúde da Criança e do Adolescente}

Nos últimos anos ocorreram muitos avanços no campo da saúde das crianças, no Brasil, oportunizando melhores condições de vida para os cidadãos como um todo. Do mesmo modo, conforme previsão contida no Estatuto da Criança e do Adolescente - ECA, ocorreu, concomitantemente, avanço nas políticas públicas de saúde. Pode-se citar, como exemplo, o Programa de Saúde Materno-Infantil, criado na década de 1960, o qual foi incorporado a políticas mais amplas de expansão da saúde pública na década de 1990, com os Programas de Saúde da Família e de Agentes Comunitários de Saúde. A partir da criação e valorização 
dos serviços de Atenção Primária à Saúde (APS), deu-se a promoção da interiorização de certas categorias profissionais e a oportunização do acesso à rede de saúde, gerando bons resultados acerca dos índices de saúde das crianças (SILVA, 2019).

Ainda sobre tais índices, destaca-se que as políticas públicas de atenção à saúde da criança oportunizaram a redução da mortalidade infantil, o aumento da cobertura vacinal, a ampliação do acesso aos serviços de saúde, o aumento do aleitamento materno e a diminuição da desnutrição (BRANQUINHO, 2018). O aumento do acesso à Atenção Básica no país foi fundamental na análise dos índices assistenciais e da real situação de saúde das crianças.

Programas para imunização, proteção, apoio ao aleitamento materno, assessoramento do crescimento e desenvolvimento e prevenção e controle das doenças diarreicas e respiratórias foram realizados nos últimos anos (MINISTÉRIO DA SAÚDE, 2018).

Contudo, os cartazes que circulam sobre a saúde da criança e do adolescente abordam assuntos relacionados à prevenção da obesidade infantil e à prevenção da gravidez na adolescência. Tal situação indica que ainda são necessários maiores investimentos ligados aos processos elencados anteriormente, relativos à nutrição e APS enquanto suporte nacional para crianças e suas famílias. Por outro lado, apontam a emergência de outras preocupações que também precisam receber investidas pela perspectiva educacional. Nota-se a preocupação do MS em prevenir estes problemas de saúde pública.

\section{Saúde da Mulher e da Gestante}

No Brasil, constata-se que existem diferenças entre homens e mulheres, principalmente se observarmos as diferenças de remuneração entre tais e o fato de os cargos de chefia serem, em grande parte, ocupados por homens. Para além disso, é possível mencionar que a incidência de atos violentos contra muIheres é alta (FREITAS, 2009). 
Neste contexto, diversos autores analisam o risco da morte materna em relação aos níveis de escolaridade das gestantes, tendo em vista os fatores socioeconômicos apresentados. Quando a mulher tem baixa escolaridade tende a não comparecer na unidade de saúde para início do pré-natal, bem como para as consultas de praxe. Tal situação se estende ao fato de as crianças, frequentemente, apresentarem baixo peso ao nascer e à mortalidade infantil. Já com relação à morte materna, é situação excepcional que acontece na gravidez, no parto e puerpério, cujas causas podem não estar apenas ligadas ao contexto clínico, mas também a outros fatores (COSTA, 2005).

As políticas de atenção à saúde da mulher foram muito relevantes para o processo de transformação relacionado à saúde da mulher. Depende, logicamente, de mudanças sociais, que estão em constante evolução. Nesse sentido, primeiramente prioriza-se alguns grupos, sendo que se pode citar as mulheres indígenas, lésbicas e presidiárias, porém também o sistema de saúde tem dificuldades no atendimento de tais grupos de mulheres (FREITAS, 2009).

Partindo dos cartazes disponibilizados no portal do MS, pode ser dito que as campanhas que abordam a saúde da mulher e da gestante enfatizam, sobretudo, a doação de leite materno. Conforme mencionam, esta prática pode prevenir muitas doenças relacionadas aos bebês. Nesta direção, pode-se pensar que outros temas considerados urgentes, relacionados à violência ou desigualdade de gênero são deixados para trás, tendo em vista que o aleitamento materno é o foco do material didático oferecido pelo MS. Certamente, o aleitamento materno é relevante, mas deve-se haver equilíbrio no que se refere às práticas de educação em saúde.

\section{Infecções Sexualmente Transmissíveis}

A Organização Mundial da Saúde (OMS) estima que mais de 1 milhão de pessoas adquirem, ao menos, uma Infecção Sexualmente Transmitida (IST), diariamente. No mundo, 500 milhões de pessoas adquirem IST curáveis, como gonorreia, clamídia, sífilis e tricomoníase (ALMEIDA, 2019). As IST, devido à alta 
prevalência, podem ser compreendidas como um problema de saúde pública, podendo ser observadas de forma aguda ou ocasionando sequelas, como processos inflamatórios pélvicos, infertilidade e morbidade perinatal. Essas consequências geralmente decorrem da ausência de diagnóstico ou tratamento adequado, sendo denominadas sequelas crônicas (LUPI, 2011).

Muitos esforços são realizados para ampliar o acesso universal e de forma gratuita aos preservativos, a exemplo do que o Departamento Nacional de DST, Aids e Hepatites Virais e o Programas Estaduais e Municipais de DST/Aids vêm propondo. Dessa maneira, aumenta-se a prática de sexo protegido, estratégia destinada a reduzir a ocorrência de IST, inclusive o HIV. Além disso, a divulgação sobre como as IST são transmitidas, seus sinais clínicos e seus sintomas, são de extrema importância para aumentar o conhecimento da população e, assim, proporcionar a busca rápida por assistência (PINTO, 2018).

Com a análise dos cartazes, percebemos que a grande maioria das campanhas utilizavam meios de prevenção a respeito dos temas abordados, citando, por exemplo, a importância do uso de preservativos, a necessidade de procurar por atendimento médico quando identificado algum sinal ou sintoma de alguma IST, a importância de se seguir as orientações de tratamento e, sobretudo, informando à população como se prevenir dessas doenças.

\section{Saúde do Homem}

A discussão referente à saúde do homem e a sua inserção nos serviços de saúde está acontecendo mais recentemente. Sabe-se que os homens vivem, em média, sete anos menos que as mulheres, sendo mais acometidos por doenças cardiovasculares, neoplasias, diabetes mellitus, hipertensão arterial, ou seja, são mais propensos às doenças graves e crônicas (LEMOS, 2017).

A Política Nacional de Atenção Integral à Saúde do Homem segue em concordância com a Política Nacional de Atenção Básica e a Equipe Estratégia Saúde da Família, que são as ações principais do SUS. Ambas têm como objetivo promover ações de saúde que auxiliem de forma significativa para a análise do 
homem de forma íntegra, com intuito de aumentar a expectativa de vida e diminuir as taxas de morbimortalidade por causas evitáveis (CARNEIRO, 2019).

São muitos os obstáculos que devem ser superados para que seja conscientizada a população masculina de sua necessidade de cuidar da saúde de forma preventiva. Devido à organização dos serviços de saúde, sua falta de estímulos, observado, inclusive, pelas poucas campanhas voltadas a esse público, observa-se a deficiência dos serviços de saúde em absorver a população masculina. Desse modo, são necessárias mudanças nas estratégias dos serviços, com o objetivo de atrair esse segmento (LEMOS, 2017).

Foi observado na análise do material, esse mesmo cenário, já que apenas um cartaz é direcionado à atenção da saúde do homem. Entende-se que tal realidade precisa ser modificada, tendo em vista que há preocupações estatais, de mais tempo, relacionadas ao tema. Ainda, acredita-se que materiais sobre o tema deveriam ser disponibilizados em ambientes de trabalho e lazer em que há maior número de frequentadores homens.

\section{CONSIDERAÇÕES FINAIS}

Ao analisar os cartazes desenvolvidos pelo MS, percebe-se que as campanhas de prevenção de doenças, apesar de abordarem temáticas variadas e objetivarem públicos-alvo diferentes, convergem para um princípio em comum: educar para prevenir. A aprendizagem proporcionada por anúncios marcantes, frases claras e imagens explicativas não apenas conscientiza homens, mulheres e crianças quanto aos processos de adoecimento, como também incentiva a construção de hábitos de vida saudáveis, a exemplo da vacinação, da higiene pessoal e ambiental, da boa alimentação, da prática de esportes e do autocuidado. Além disso, as mensagens presentes nas campanhas oportunizam um momento para pensar na coletividade, estimulando ações humanitárias e a própria promoção da saúde por parte da população brasileira.

Com o estudo dos cartazes, foi identificado também que o Brasil investe muito mais em campanhas que ressaltam a prevenção de doenças do que a pro- 
moção da saúde, o que pode ser característico de países em desenvolvimento ou de países não desenvolvidos. Conforme Buss (2007), para resolver os problemas de saúde de países em que há muita pobreza, as organizações internacionais preconizam reformas que resultam em iniquidades em saúde, oferecendo atendimento médico para indivíduos já doentes, não havendo, portanto, espaço para abordar a promoção da saúde e desenvolver a qualidade de vida.

Portanto, por mais que o MS invista em campanhas de prevenção de doenças, ainda persistem problemas de saúde. Com investimentos em promoção da saúde, esses problemas poderiam ser resolvidos de fato. Além disso, destacamos que é muito importante o desenvolvimento da promoção da saúde em nível global, visto que muitas sociedades, assim como o Brasil, enfrentam problemas de saúde que podem ser contornados a longo prazo.

Os cartazes são importantes ferramentas educativas, sendo um material didático muito importante a respeito do contexto de saúde dos países. Por isso, a sua utilização pode revelar muitas possibilidades de reflexões. Espera-se, assim, que cada vez mais os cartazes sejam utilizados como ferramenta educativa, não apenas para prevenção de doenças, mas também para a promoção da saúde.

\section{REFERENCIAS}

ALMEIDA, M.M, PEREIRA, K.A.A. Educação e orientação sexual e prevenção das IST'S: ênfase para os riscos do papilomavírus humano (HPV). XVI Congresso NUPIC. 2019. Acesso em:< https://publicacoes.fafire.br/diretorio/nupic/ nupic_2019_06.pdf >. Acesso em: 12 out. 2021.

CARNEIRO, V.S.M.; ADJUNTO, R. N. P.; ALVES, K. A. P. Saúde do homem: identificação e análise dos fatores relacionados à procura, ou não, dos serviços de atenção primária. Arquivo Ciência Saúde UNIPAR, Umuarama. 2019. Disponível em: < https://www.revistas.unipar.br/index.php/saude/article/view/6521>. Acesso em: 12 out. 2021.

COSTA, M.C, GUILHERM, D, TELLES, M.I.M. Atendimentos a gestantes no Sistema Único de Saúde. Revista Saúde Pública. 2005. Disponivel em:< https:// www.scielo.br/j/rsp/a/QwZ8zLsjrp64P9F7Z8KBLzm/?lang=pt>. Acesso em: 12 out. 2021. 
BARRETO, M. L. Papel da epidemiologia no desenvolvimento do Sistema Único de Saúde no Brasil: histórico, fundamentos e perspectivas. Revista Brasileira de Epidemiologia, BA, Brasil, v. 5, 2002. Disponível em: https://www.scielosp.org/ article/rbepid/2002.v5suppl1/4-17/. Acesso em: 7 out. 2021.

BERTASI, R. A. O. et al. Perfil dos potenciais doadores de órgãos e fatores relacionados à doação e a não doação de órgãos de uma Organização de Procura de Órgãos. Revista do Colégio Brasileiro de Cirurgiões, São Paulo, 2019. Disponível em: https://www.scielo.br/j/rcbc/a/ZL75x5Pkv7FRTJ6TsDLFMzC/?lang=pt\#: :text=Do\%20total\%2C\%20681\%20(38\%2C,98\%25)\%20do\%20sexo\%20 masculino. Acesso em: 9 out. 2021.

BLOOM, M. et al. Evolving Definitions of Primary Prevention. In: GULLOTTA, T.P. et al. Encyclopedia of Primary Prevention and Health Promotion. Boston, MA: Springer, 2003. p. 9-10. Disponível em: https://link.springer.com/ book/10.1007/978-1-4615-0195-4. Acesso em: 4 out. 2021

BRANQUINHO, I.D, LANZA, F.M. Saúde da criança na atenção primária: evolução das políticas brasileiras e a atuação do enfermeiro. Revista Enfermagem do Centro Oeste Mineiro. 2018. Disponível em:< http://seer.ufsj.edu.br/index.php/ recom/article/view/2753/1980>. Acesso em: 12 out. 2021.

BRASIL. Ministério da Saúde. Secretaria de Vigilância em Saúde. Vigilância em Saúde no Brasil 2003 - 2019, 2019. Disponível em: https://portalarquivos2. saude.gov.br/images/pdf/2019/setembro/25/boletim-especial-21ago19-web.pdf. Acesso em: 8 out. 2021.

BRASIL. Ministério da Saúde. Secretaria de Atenção à Saúde. Departamento de Atenção Básica. Rastreamento. Brasília, 2013. Disponível em: https://bvsms. saude.gov.br/bvs/publicacoes/rastreamento_caderno_atencao_primaria_n29. pdf. Acesso em: 4 out. 2021.

BUSS, P. M. Globalização, pobreza e saúde. Ciência \& Saúde Coletiva, v. 12, n. 6, 2007. P. 1575-1589 Disponível em: < https://www.Scielosp.org/article/csc/2007. v12n6/1575-1589/>. Acesso em: 11 out. 2021.

DARSIE, C.; HILLESHEIM, B.; WEBER, D. L. Paisagens biopolíticas: a produção da saúde, beleza e potência corporal dos sujeitos fumantes e não fumantes. Momento - Diálogos em Educação. v. 26, n. 2, p. 89-107, 2017. Disponível em: https://periodicos.furg.br/momento/article/view/7346. Acesso em: 14 out. 2021. 
FREITAS, G.L, VASCONCELOS, C.T.M, MOURA, E.R.F, PINHEIRO, A.K.B. Discutindo a política de atenção à saúde da mulher no contexto da promoção da saúde. 2009. Disponível em: < https://revistas.ufg.br/fen/article/view/47053>. Acesso em: 12 out. 2021.

FUNASA, Educação em Saúde: diretrizes, Brasília: Funasa, 2007, p. 21.

INFORME TÉCNICO. Ministério da Saúde, 2019. Disponível em: <https://portalarquivos2.saude.gov.br/images/pdf/2019/marco/01/Informe-Cp-Influenza-29-02-2019-final.pdf>. Acesso em: 11 out. 2021.

JUNIOR, J.B.S. 40 anos do Programa Nacional de Imunizações: uma conquista da Saúde Pública brasileira. 2013. Disponível em: <http://scielo.iec.gov.br/scielo.php?script=sci_arttext\&pid=S1679-49742013000100001>. Acesso em: 11 out. 2021.

LEMOS A.P, RIBEIRO C, FERNANDES J, BERNARDES K, FERNANDES R. Saúde do homem: os motivos da procura dos homens pelo serviço de saúde. Revenferm UFPE online. 2017. Disponível em: < https://periodicos.ufpe.br/revistas/revistaenfermagem/article/view/231205>. Acesso em: 12 out. 2021.

LUPPI. C.G, OLIVEIRA, R.L, VERAS M.A, LIPPMAN S.A, JONES, H, JESUS $\mathrm{C} . \mathrm{H}$, et al. Diagnóstico precoce e os fatores associados às infecções sexualmente transmissíveis em mulheres atendidas na atenção primária. Revista Brasileira de Epidemiologia. 2011. Disponível em:< https://www.scielo.br/j/rbepid/a/ RQFQ5DWpGFQdmrKVcCtZDJB/?lang=pt>. Acesso em: 12 out. 2021.

MENEZES, A. M. B. et al. Vacinação para influenza em idosos na pandemia COVID-19: estudo de base populacional em 133 cidades brasileiras. Pelotas. Editora Scielo, 2021.

MINISTÉRIO DASAÚDE. Política Nacional de Saúde da Criança. 2018. Disponível em: https://portaldeboaspraticas.iff.fiocruz.br/wp-content/uploads/2018/07/Pol\%C3\%ADtica-Nacional-de-Aten \%C3\%A7\%C3\%A3o-Integral-\%C3\%A0-Sa\%C3\%BAde-da-Crian\%C3\%A7a-PNAISC-Vers\%C3\%A3o-Eletr\%C3\%B4nica.pdf. Acesso em: 12 out. 2021.

PAIM, Jairnilson Silva. Epidemiologia e planejamento: a recomposição das práticas epidemiológicas na gestão do SUS. Ciência \& Saúde Coletiva, Salvador, 2003. Disponível em: https://www.scielo.br/j/csc/a/hPzrtYnZZJdQDDD39QNrMQL/?lang=pt. Acesso em: 7 out. 2021. 
PINTO, V.M, BASSO C.R, BARROS, C.R.S, GUTIERREZ, E.B. Fatores associados às infecções sexualmente transmissíveis: Inquérito populacional no município de São Paulo, Brasil. Ciência \& Saúde Coletiva. 2018. Disponível em: $<$ https://www.scielo.br/j/csc/a/wwgnzLKCkqD4pbtcJ4B76td/?lang=pt>. Acesso em: 12 out 2020.

ROSSI, Samuel Quinaud et al. Um novo olhar sobre a elaboração de materiais didáticos para educação em saúde. Trabalho, Educação e Saúde. 2012, v. 10 , n. 1 , pp. 161-176. Disponível em: <https://doi.org/10.1590/S198177462012000100010>. Epub 27 Mar 2012. ISSN 1981-7746. https://doi. org/10.1590/S1981-77462012000100010. Acesso em: 11 out. 2021.

SILVA, G.S, FERNANDES, D.R.F, ALVES C.R.L. Avaliação da assistência à saúde da criança na Atenção Primária no Brasil: Revisão sistemática de métodos e resultados. Ciência \& Saúde Coletiva. 2019. Disponível em:< https://www.scielo. $\mathrm{br} / \mathrm{j} / \mathrm{csc} / \mathrm{a} / \mathrm{SD} 445 x F n C b T K Z V 9 B s X G G t c L / a b s t r a c t /$ ?lang=pt>. Acesso em: 12 out. 2021.

STARFIELD, B. et al. The concept of prevention: a good idea gone astray?. J Epidemiol Community Health, [s. I.], 2008. Disponível em: https://pubmed. ncbi.nlm.nih.gov/18559439/. Acesso em: 4 out. 2021. 




\section{IFMSA BRASIL UNISC:}

\section{EXPERIÊNCIAS DE EDUCAÇÃO EM SAÚDE VIVIDAS POR ESTUDANTES DE MEDICINA QUE FAZEM A DIFERENÇA}

Henrique Ziembowicz, Fernanda Wartchow Schuck

Barbara Taynara Michielin, Laura Schmidt Rizzi

Vinicius Do Nascimento Rodrigues, Bruna Mallmann Specht

Ana Paula Backes, Carolina Loebens Hinterholz

Catiane Kelly Schaefer, Felipe Santos Silveira

Giovana Maria Fontana Weber, Mariana Wallauer Reinheimer

Sabrina Abed, Marina Cervo Pinheiro Machado Laura Paveglio Schmidt, Larissa De Camargo Subtil Arthur Gomes Ribeiro, Maria Eduarda Ferreira Zanin Anna Lya Assmann Da Motta, Eduarda Rebés Müller Isadora Fussiger Theissen, Jorgana Vargas Peruzzo Luiza Dalla Vecchia, Camilo Darsie 


\section{INTRODUÇÃO}

Fundada em 1951, a International Federation of Medical Students Associations $^{1}$ (IFMSA) é reconhecida pela Organização das Nações Unidas (ONU), Organização Mundial da Saúde (OMS) e Organização das Nações Unidas para a Educação, a Ciência e a Cultura (UNESCO). Ela chegou ao Brasil em 1991 e, atualmente, conta com oito mil estudantes no Brasil, em mais de 220 escolas médicas. Em todo globo, a soma alcança um milhão de estudantes, os quais se encontram em 130 países. A IFMSA reúne e educa estudantes de medicina para a prevenção e promoção de saúde de forma qualificada e equânime, além de possibilitar troca de experiências nacionais e internacionais.

Em sua organização, a federação apresenta seis eixos de atividade, a saber: Educação Médica, Saúde Pública, Direitos Humanos e Paz, Saúde Sexual e Reprodutiva, Intercâmbio, e Pesquisa. Com isto em mente, o Comitê local da Universidade de Santa Cruz do Sul (UNISC), fundado em 2019, promove reuniões e capacitações de seus 34 membros, incentiva a atuação universitária a partir da coordenação de eventos e ações destinadas à comunidade e, por fim, estimula o desenvolvimento de habilidades como cooperação e liderança.

Dada a organização e os objetivos da Federação, entende-se que tanto os processos de trabalho quanto de assistência à comunidade caracterizam-se como práticas de educação em saúde, visto que se alinham aos princípios que orientam as políticas públicas de saúde e educação brasileiras.

\section{A IFMSA BRASIL UNISC}

A IFMSA Brasil UNISC, a partir da interseccionalidade de seus comitês alinhavados à pesquisa e publicação, pretende, neste escrito, apresentar uma obra de divulgação científica relativa aos processos de educação em saúde. Os conteúdos divulgados compreendem ações e projetos desenvolvidos durante os anos de 2020 e 2021. Assim, os comitês serão apresentados um a um, ficando à parte o eixo de atividade relacionado aos Intercâmbios - por não atender aos 
objetivos do capítulo - e o eixo relacionado à Pesquisa - por ser o pano de fundo integrador dos escritos

\section{COMITÊ PERMANENTE DE EDUCAÇÃO MÉdICA: EM PROL DA EDUCAÇÃO MÉDICA DE QUALIDADE}

O Standing Committee On Medical Education (SCOME) ou Comitê Permanente de Educação Médica refere-se a um órgão da IFMSA, que visa construir uma educação médica de qualidade, a partir do esforço dos próprios estudantes dos cursos de medicina, como atuantes diretos na criação, desenvolvimento e implementação de sistemas de educação médica. Dessa forma, busca mudanças sustentáveis em nível mundial, não apenas para os estudantes, como também futuros pacientes, usuários dos sistemas públicos de saúde e comunidade.

Nesse contexto, o SCOME da IFMSA Brasil UNISC atua junto à comunidade santacruzense, alinhado à missão e aos objetivos do comitê. Um exemplo disso é o evento intitulado "Comunicação de Más Notícias", que consistiu em uma palestra online, com a participação de três palestrantes, abordando as habilidades necessárias ao profissional da saúde diante do ato de comunicar uma má notícia. São profissionais da área da saúde que mais enfrentam o desafio de comunicar situações que envolvem o bem-estar físico e mental e o prognóstico dos pacientes, frente aos desfechos clínicos. Esses desfechos podem ser desfavoráveis, configurando más notícias.

É considerada uma má notícia "toda a informação que envolva uma mudança drástica e negativa na vida da pessoa e na perspectiva do futuro" (BUCKMANN, 1992). Tal situação leva a diversos sentimentos, tanto para quem comunica quanto para quem recebe a notícia. Dor, ansiedade, medo, angústia, sentimentos de inutilidade e desconforto são comuns, haja vista que anunciar um diagnóstico ou prognóstico de enfermidade representa uma grande dificuldade por parte dos profissionais (PEREIRA, 2005). 
Diante disso, o comitê julgou importante abordar esse assunto a fim de preparar estudantes da área da saúde para o futuro, haja vista que se observa uma falha formativa caracterizada pelo fato de, muitas vezes, os estudantes serem inseridos diretamente na prática clínica, sem qualquer auxílio ou preparo para comunicar más notícias (VOGEL, et al., 2019).

A realização do evento apresentou boa adesão por parte dos estudantes de cursos da área da saúde de várias universidades do país. Os participantes apresentaram, ao final, reflexões sobre suas atitudes mediante cenários que exigem comunicação de más notícias. Ademais, a abordagem desse tipo de comunicação na prática médica em si, relatada pelas palestrantes colaborou para a elucidação da temática e aquisição de conhecimento para o exercício da profissão.

Sendo assim, o evento em questão exemplifica a fundamentação do Comitê Permanente de Educação Médica, que coloca estudantes de medicina como transformadores de sua formação e currículo, buscando sanar falhas de aprendizado e abrir espaços para discussões pertinentes, a fim de formar profissionais melhor capacitados e preparados para atender a população e suas demandas.

\section{COMitê PERManente em saúde pública Na IFMSA BRASIL UNISC: UMA CAMPANHA}

Estabelecido pelo artigo 196 da Constituição Brasileira, a saúde "é direito de todos e dever do Estado, garantido mediante políticas sociais e econômicas que visem à redução do risco de doença e de outros agravos e ao acesso universal e igualitário às ações e serviços para sua promoção, proteção e recuperação" (SOUZA, et al., 2019). Nesse contexto, entra o conceito de Saúde Pública, o qual engloba todas as ações oriundas do Estado com a finalidade de garantir esse direito universal à população.

É inegável que há disparidade nesse acesso em um país de dimensões continentais como o Brasil. Assim, é de fundamental importância o papel dos profissionais e estudantes da área da saúde na educação em saúde, através 
do empoderamento da população pelo acesso à informação nas mais diversas áreas, desde os processos biológicos que envolvem as histórias naturais de doenças até a importância dos Determinantes Sociais de Saúde (DSS). Dentro da IFMSA, o Standing Committee On Public Health ${ }^{2}$ (SCOPH) tem como objetivo a promoção de saúde pública nas mais diversas áreas, por meio de ações que visam à prevenção de doenças e o empoderamento da população através da ampliação de práticas de educação em saúde, dentro e fora do meio acadêmico.

$\mathrm{Na}$ atual crise política, econômica e social, exacerbada pela pandemia da SARS-CoV-2, com a superlotação do sistema de saúde, houve o retardamento no diagnóstico e rastreio de muitas doenças, como é o caso do câncer colorretal - que, para pessoas com risco médio, o rastreio através de colonoscopia deve-se iniciar aos 45 anos, conforme recomendações (AMERICAN CANCER SOCIETY., 2020). No entanto, nos últimos anos, com as altas taxas de transmissão do Coronavírus e com a prioridade dos serviços de saúde para essa patologia, muitas pessoas deixaram de realizar rastreios preventivos para outras doenças, tranquilizadas pela falsa ideia de não apresentarem sintomas para tais.

Partindo disto, o SCOPH da IFMSA Brasil UNISC desenvolveu a ação "Setembro Verde: Conscientização à prevenção do Câncer de Intestino". Com a possibilidade segura de retomada às campanhas presenciais, essa atividade foi executada em uma Estratégia de Saúde da Família (ESF) de Santa Cruz do Sul, com o objetivo de democratizar o conhecimento sobre o câncer colorretal, por meio de panfletos, diálogos e espaços para os usuários do Sistema Único de Saúde (SUS) sanarem suas dúvidas sobre a temática. As informações repassadas envolvem o que é câncer de intestino, como prevenir, quais são seus sintomas, fatores de risco, seus exames de rastreio e sua população alvo.

Ainda, foi possível dimensionar o conhecimento obtido com a campanha, recorrendo a um questionário, quantificando e qualificando o repasse dessa consciência de prevenção do câncer colorretal para a população local. O SCOPH acredita na importância de articular a comunidade ao ambiente universitário,

$2 \quad$ Comitê Permanente em Saúde Pública. 
de levar a educação em saúde para além da universidade e de interagir com as necessidades de cada localidade, considerando os Determinantes Sociais de Saúde e as especificidades de populações e de grupos sociais em situações de maior vulnerabilidade.

Dessa forma, o Comitê de Saúde Pública da IFMSA Brasil UNISC visa informar e alertar a população por meio de campanhas, de palestras e de publicações em redes sociais e busca demonstrar a importância da prevenção, do diagnóstico precoce e do tratamento adequado de diferentes doenças físicas e mentais a fim de reduzir agravos e ampliar o acesso à saúde e aos cuidados médicos para a comunidade santacruzense.

\section{COMITÊ PERMANENTE EM DIREITOS HUMANOS: UM OLHAR SOBRE POPULAÇÕES NEGLIGENCIADAS}

A disseminação do SARS-CoV-2 ao final do ano de 2019, produziu, nos diversos âmbitos da gestão pública, dos serviços e na assistência em saúde (trans)formações que ainda não estão bem elucidadas. Neste âmbito, seria correto afirmar que a crise causada pela pandemia impactou, também, de forma direta e indireta os Direitos Humanos e a Paz. Nesta mesma linha de pensamento, emerge a importância das ações promovidas pelo Standing Committee on $\mathrm{Hu}$ man Rights and Peace ${ }^{3}$ (SCORP), que se caracteriza por possibilitar a mobilização de estudantes de medicina em ações que promovem e protegem os direitos humanos e a paz em sua prática cotidiana, visando assegurar direitos básicos e igualitários.

O comitê promoveu projetos enfocados, principalmente, em populações vulneráveis - as quais, em boa parte do tempo, não possuem a plenitude de seus direitos. Em face a isto, cabe ao estudante de medicina compreender as especificidades de cada público a fim de exercer a medicina de forma ética e inclusiva. Assim, o SCORP produziu conteúdos tais quais: "Transexualidades: limite e possibilidades de acesso à saúde"; "A saúde indígena em perspectiva"; "Crise dos

3 Comitê Permanente em Direitos Humanos e Paz. 
refugiados"; "Combate ao abuso e à exploração sexual de crianças e adolescentes"; "Combate ao trabalho infantil”; "Consciência negra".

Visando chamar a atenção da comunidade geral para os problemas enfrentados pela Crise de refugiados, o Comitê desenvolveu publicações informativas na rede social Instagram. A motivação decorreu, também, por completar 10 anos, em 2021, do início da Guerra na Síria - situação na qual desencadeou o deslocamento de milhões de crianças, mulheres e homens refugiados (GOMES et al., 2017; SILVA, 2019).

Em relação ao Combate ao Trabalho Infantil, a informação ocorreu por meio de profissionais capacitados, em vista de ser considerado ilegal pelo Estatuto da Criança e do Adolescente desde 1990 (BRASIL, 2017). Ainda, na mesma perspectiva, a fim de potencializar a discussão, identificar e combater a exploração na infância, o SCORP convidou duas profissionais - uma assistente social e uma médica pediátrica - com experiência no manejo de situações que envolvem a temática para elaborar um post que relaciona os aspectos sociais e de saúde que interferem na vida das vítimas.

O fenômeno do trabalho infantil é uma expressão da questão social que está, infelizmente, presente em todo nosso país, independentemente de região, classe social ou tempo histórico. A Sociedade Brasileira de Pediatria (SBP), historicamente, posiciona-se contra tal prática nociva, com base em dados técnicos que atestam os prejuízos desta atividade, alertando para a legislação vigente e para os acordos internacionais dos quais o Brasil é signatário.

Em alusão ao Dia Nacional da Consciência Negra, a valorização do pensamento negro enquanto um expoente contribuinte para o desenvolvimento da medicina elaborou-se uma publicação que relacionava a trajetória de médicos e médicas negras e a inserção de suas técnicas na prática médica e além disso foi problematizado o baixo percentual de profissionais médicos formados e alunos negros no curso de medicina o que reflete a estruturação educacional racista e elitizada dos cursos considerados de excelência. 
O evento intitulado Transexualidades: limite e possibilidades de acesso à saúde, resultante de uma parceria com o AmbiTrans (Ambulatório Multiprofissional de Atenção à Saúde da População LGBTQIA+) da UNISC, oportunizou uma roda de conversa com profissionais envolvidos na inclusão desta população minoritária, além de suas vivências e empecilhos quando buscam atendimento médico. O evento intitulado $A$ saúde indígena em perspectiva abordou a percepção sobre a escassez de informação relacionada à saúde da comunidade indigena a partir de uma roda de conversa em que foram convidados palestrantes capacitados para falar sobre a temática, sendo três médicos especialistas em saúde indígena e uma indigena técnica em enfermagem. Neste evento, o comitê buscou enfatizar a importância do tema visto que ele é amplamente ignorado no meio acadêmico.

\section{COMITÊ PERMANENTE EM SAÚdE E DIREITOS SEXUAIS E REPRODUTIVOS, INCLUINDO HIV E AIDS: GARANTINDO QUALIDADE DE VIDA E LIBERDADE}

Garantidas através da Declaração Universal dos Direitos Humanos, adotada em 1948, Saúde Sexual e Saúde Reprodutiva são dois eixos essenciais no que se refere à qualidade de vida e liberdade. Promover acesso aos direitos universais é possibilitar igualdade e acessar diferenças, respeitando-as e possibilitando que os indivíduos exerçam sua cidadania de forma plena por meio de uma existência única e sem discriminação (BRASIL, 2013). Desse modo, o SCORA busca atuar de forma a garantir o debate de tópicos relevantes que assolam essa temática, dado que se acredita na capacidade de mudança e de consciência crítica proveniente dos estudantes de medicina e dos profissionais da área da saúde.

Nesse comitê permanente, objetiva-se que os indivíduos estejam empoderados para exercitar seus direitos sexuais e reprodutivos equitativamente, livres de estigmas e discriminação. Atuantes em temas que incluem sexualidade e identidade de gênero, educação sexual compreensiva e saúde materna, percebeu-se a necessidade, em face à pandemia global que vivenciamos, de uma atuação em outro eixo que se relaciona à saúde sexual e reprodutiva: a violência de gênero. 
Apesar de compreender-se que a violência contra mulher não é um fenômeno unicamente contemporâneo, é notável que a visibilidade política e social desta problemática é de caráter recente. A origem de tal violência perpassa os valores machistas e patriarcais arraigados em nossa cultura e estruturantes em nossa sociedade que se presume estarem associados à grave recorrência das violências cometidas contra as mulheres e às severas desigualdades de poder e de direitos enfrentados por elas na sociedade (GUIMARÃES, 2015).

Percebe-se que a crise sanitária, econômica e social trazida pela pandemia de Covid-19 e pelas necessárias medidas de enfrentamento que precisaram ser tomadas aumentou o risco de violência contra a mulher, fazendo com que ocorresse a manutenção e o agravamento das situações de violência já instaladas (MARQUES, 2020). Assim, durante a pandemia, são evidentes no país os relatos de aumento da violência doméstica concomitantes à diminuição do acesso aos serviços de apoio às vítimas, o que se deve à redução das atividades trabalhistas em tais setores e ao distanciamento social, que propiciou o isolamento das muIheres nos seus domicílios, próximas de seus agressores, vigiadas e com menor contato com as suas redes socioafetivas.

Nesse contexto, evidenciou-se a necessidade de promover ações de Educação em Saúde que sinalizassem para um diálogo e um amparo a essas vítimas de violência ou, ainda, que possibilitassem o diagnóstico desses casos. Um exemplo foi a realização do seminário intitulado "Violência Doméstica contra a Mulher na Pandemia" que ocorreu por webconferência e contou com abordagens acerca dos conceitos da violência em seus aspectos psicossociais e, também, voltados a aspectos da área da saúde. A abordagem acerca dos direitos das muIheres, das formas de proteção pelas leis e pelas políticas públicas, da abordagem médica e os dados levantados pelas palestrantes foram de extrema relevância para a promoção de Educação em Saúde aos espectadores do evento - na sua maioria, profissionais que possivelmente atenderão essas vítimas na prática médica. Eventos como o que fora citado, visam construir um espaço de saberes, 
sobretudo em relação aos direitos da mulher, para então, estimular a diminuição de casos de violência.

A abordagem através da disseminação de informações, com um espaço seguro para debates, conversas e reflexões, confirma a relevância da comunicação e do conhecimento para a autonomia dos atores. Nessa perspectiva, acredita-se que debates e troca de informações com profissionais capacitados possibilitam o empoderamento dos indivíduos, sejam quais forem os temas e âmbitos abordados no sentido de possibilitar qualidade de vida e direitos fundamentais básicos. Assim, partindo da aquisição do conhecimento pode-se contribuir para mudar realidade e promover saúde, metas do SCORA e da IFMSA Brasil UNISC.

\section{CONCLUSÃO}

O intuito da IFMSA Brasil UNISC é desenvolver a capacitação e a motivação dos estudantes de medicina, colocando-os como agentes promotores e ativos dos direitos humanos e da paz. Em virtude disso, uma formação ampla e capaz de relacionar o dinamismo das comunidades como um elemento fundamental no processo saúde-doença dos indivíduos permite o aprimoramento da prática clínica, uma vez que os determinantes sociais em saúde estão intimamente relacionados com o nível de êxito dos direitos humanos fundamentais.

Logo, acredita-se na responsabilidade de todos, na capacidade de contribuição para a criação de um mundo mais igualitário e pacífico em que os direitos humanos só podem existir quando se aplicam a todos os seres humanos. Ademais, entende-se que tais práticas se constituem por meio do que se entende por educação em saúde, principalmente, a partir do alinhamento com as políticas públicas de saúde e educação brasileiras e da possibilidade de escuta e diálogo com comunidades que formam as populações (FALKENBERG, 2014). 


\section{REFERENCIAS}

AMERICAN CANCER SOCIETY. American Cancer Society Guideline for Colorectal Cancer Screening, 2020. Disponível em:<https://www.cancer.org/cancer/ colon-rectal-cancer/detection-diagnosis-staging/acs-recommendations.html>. Acesso em: 11. out. 2021.

BRASIL. Lei 13.431/17. Dispõe sobre o Sistema de Garantias de direitos da criança e do adolescente vítima ou testemunha de violência e altera a Lei no 8.069, de 13 de julho de 1990 (Estatuto da Criança e do Adolescente) Disponível em: <http://www.planalto.gov.br/ccivil_03/_ato2015-2018/2017/lei/l13431.html>. Acesso em: 13. out. 2021.

BRASIL. Saúde sexual e saúde reprodutiva. Cadernos de Atenção Básica, $n$. 26. $1^{a}$ edição. Brasília: Ministério da Saúde, Departamento de Atenção Básica, 2013.

BUCKMAN, Robert. How to Break Bad News: A Guide for Health Care Professionals. Baltimore: Johns Hopkins University Press 1992. 223.

FALKENBERG, Mirian Benites et al. Educação em saúde e educação na saúde: conceitos e implicações para a saúde coletiva. Ciência \& Saúde Coletiva, v. 19, n. 03, 2014 pp. 847-852. Disponível em: https://doi.org/10.1590/141381232014193.01572013

GUIMARÃES, Maisa Campos; PEDROZA, Regina Lucia Sucupira. Violência contra a mulher: problematizando definições teóricas, filosóficas e jurídicas. Psicologia \& Sociedade, v. 27, p. 256-266, 2015. https://doi.org/10.1590/ 1807-03102015v27n2p256

GOMES, Geórgia; LOPES, Joana. A crise migratória no século XXI. RIPE: Relações Internacionais para Educadores, v. 5, 2017.

MARQUES, Emanuele Souza et al. A violência contra mulheres, crianças e adolescentes em tempos de pandemia pela COVID-19: panorama, motivações e formas de enfrentamento. Cadernos de Saúde Pública, v. 36, p. e00074420, 2020. https://doi.org/10.1590/0102-311X00074420

PEREIRA, Maria Aurora Gonçalves. Má noticia em saúde: um olhar sobre as representações dos profissionais de saúde e cidadãos. Texto contexto - enferm., v. 14, n. 1, p. 33-37, 2005. https://doi.org/10.1590/S0104-07072005000100004 
SILVA, Daniela Florêncio da. O fenômeno dos refugiados no mundo e o atual cenário complexo das migrações forçadas. Revista Brasileira de Estudos de População, v. 34, p. 163-170, 2017. https://doi.org/10.20947/S0102-3098a0001

SOUZA, Luis Eugenio Portela Fernandes de et al. Os desafios atuais da luta pelo direito universal à saúde no Brasil. Ciência \& Saúde Coletiva, v. 24, p. 27832792, 2019. https://doi.org/10.1590/1413-81232018248.34462018

VOGEL, Karolyne Pricyla et al. Comunicação de más notícias: ferramenta essencial na graduação médica. Revista Brasileira de Educação Médica, v. 43, p. 314-321, 2020. https://doi.org/10.1590/1981-5271v43suplemento1-20180264 




\title{
POLÍtTCa NACIONAL
} DE EDUCAÇÃO

\section{PERMANENTE EM SAÚDE:}

\section{UM PANORAMA A PARTIR DE} OLHARES UNIVERSITÁRIOS

\author{
Bianca Bortolini \\ Camila Rabuske Limberger \\ João Pedro Barros Carús \\ Laura Paveglio Schmidt
}




\section{INTRODUÇÃO}

A Política Nacional de Educação Permanente em Saúde (PNEPS), fomentada após a criação da Secretaria da Gestão do Trabalho e da Educação na Saúde (SGTES), em 2003, visa a formação de uma estratégia, do Sistema Único de Saúde (SUS), para a formação e desenvolvimento de trabalhadores do setor saúde. Ela foi consolidada por meio das portarias GM N¹98/2004 e GM $N^{0} 1.996 / 2007$. Tais portarias propõem que a qualificação dos trabalhadores e todo o processo inerente tomem como referência as necessidades e as realidades locais de saúde, objetivando a transformação das práticas profissionais e a própria organização do trabalho.

A integração dos processos de desenvolvimento de pessoas, nesse âmbito, leva em consideração as perspectivas de multidisciplinaridade, interdisciplinaridade e intersetorialidade. Conforme apontam Silva e Scherer (2020), "a condução da PNEPS está ancorada nos marcos teóricos e metodológicos da EPS ${ }^{1}$, compreendida como uma estratégia político-pedagógica que toma como objeto os problemas e as necessidades do processo de trabalho em saúde" (p. 2).

Vale ressaltar que a GM/MS N¹.996/2007, a mais recente, se adequou à implantação do Pacto pela Saúde, aprovado pelos gestores do SUS, na reunião da Comissão Intergestores Tripartite do dia 26 de janeiro de 2006 (MINISTÉRIO DA SAÚDE, 2006). Ela tem por objetivo um conjunto de reformas institucionais do SUS, pactuado entre as três esferas de gestão (União, Estados e Municípios) com o objetivo de promover inovações nos processos e instrumentos de gestão, visando alcançar maior eficiência e qualidade das respostas do sistema de saúde brasileiro.

A implementação da PNEPS em níveis municipal e estadual foi objeto de análise de diferentes estudos que evidenciaram a existência de desafios para a consolidação da área de Recursos Humanos em Saúde (RHS) no Brasil. Dessa

1 Educação Permanente em Saúde. 
forma, com o intuito de superar os fatores limitadores da viabilização integral da política, iniciou-se, em 2017, o processo denominado de "retomada da PNEPS", capitaneado pelo Ministério da Saúde. Nesse contexto, criou-se, além de outras medidas, o Programa para o Fortalecimento das Práticas de Educação Permanente em Saúde no Sistema Único de Saúde (PRO EPS-SUS) (SILVA; SCHERER 2020, p. 2).

Partindo de tais acontecimentos, o presente manuscrito apresenta um breve panorama da implementação e continuidade da PNEPS, apontando algumas modificações ocorridas ao longo dos anos, sua aplicabilidade, assim como os obstáculos que permeiam esse cenário no Brasil.

\section{PNPES: UM PANORAMA}

O processo de implementação da PNEPS nos estados e municípios foi composto por avanços e dificuldades evidenciadas pelo Departamento de Gestão da Educação na Saúde (DEGES) e por diferentes estudos (FERRAZ et al., 2014; NICOLETTO, 2013; MACÊDO et al., 2014; FRANÇA et al., 2016).

Diante deste diagnóstico, a Secretaria da Gestão do Trabalho e da Educação na Saúde, por meio do DEGES, em parceria com o Conselho Nacional de Secretários de Saúde (CONASS), Conselho Nacional de Secretarias Municipais de Saúde (CONASEMS), Conselho Nacional de Saúde (CNS), Escolas Técnicas do SUS (ETSUS), Escolas de Saúde Pública (ESP), Instituições de Ensino Superior (IES), Organização Pan-Americana da Saúde (OPAS) e demais secretarias do MS, deu início ao processo de discussão sobre a PNEPS, com o intuito de debater coletivamente estratégias para atualizar a Portaria GM/MS N 1996/2007 (BRASIL, 2018).

Para isso, foram realizadas oficinas regionais que reuniram cerca de 380 participantes, representantes das diversas instituições envolvidas no planejamento, programação, execução e avaliação das ações de EPS. Destaca-se, neste contexto, que: 
A EPS é uma estratégia político-pedagógica que toma como objeto os problemas e necessidades emanadas do processo de trabalho em saúde e incorpora o ensino, a atenção à saúde, a gestão do sistema e a participação e controle social no cotidiano do trabalho com vistas à produção de mudanças neste contexto. Objetiva, assim, a qualificação e aperfeiçoamento do processo de trabalho em vários níveis do sistema, orientando-se para a melhoria do acesso, qualidade e humanização na prestação de serviços e para o fortalecimento dos processos de gestão político-institucional do SUS, no âmbito federal, estadual e municipal (BRASIL, 2018, p. 13).

As oficinas evidenciaram a complexidade dos processos de gestão em relação à implementação da PNEPS, em todo o território nacional. Como motivos para tal realidade, listaram fatores e ressaltaram, entre eles, a falta de compreensão, por parte de muitos gestores, acerca da importância das ações de Educação Permanente em Saúde no que diz respeito à qualificação da gestão e à melhoria da atenção à saúde no SUS. O processo também destacou que não havia necessidade de mudanças no conteúdo da PNEPS, apenas a revisão de algumas nomenclaturas constantes na portaria. Ressaltou-se, ainda, a importância de se manter a PNPES como uma política pública, já que é fundamental para o bom funcionamento do SUS. Ela age para a requalificação dos profissionais e trabalhadores de saúde com vistas à melhoria da qualidade dos serviços prestados à população (BRASIL, 2018).

Vale destacar que foi nesse contexto que instituiu-se o PRO EPS-SUS, que busca a recuperação do fluxo de financiamento da proposta. Posto isso, torna-se importante compreender e ressaltar os fatores que favorecem ou dificultam a trajetória de implementação da PNEPS, na perspectiva de atores que a promovem. De acordo com Silva e Scherer (2020) o Programa foi instituído para prover apoio técnico institucional e financeiro às instâncias locais, prevendo, aos estados e Distrito Federal (DF), incentivo de custeio para a elaboração de planos estaduais de EPS e, aos municípios e DF, incentivo para a execução de ações de EPS junto às equipes da Atenção Básica.

Ainda, destaca-se o incentivo ao envolvimento dos trabalhadores que aplicam a EPS nos territórios em que atuam, os momentos de debates e pactuações 
- em especial as que envolvem as Comissões Intergestores Regionais (CIR) e as Comissões de Integração Ensino-Serviço (CIES) - e as instâncias intersetoriais e interinstitucionais permanentes que participam da formulação, condução, monitoramento e avaliação da PNEPS (SILVA; SCHERER, 2020; FRANÇA et al., 2017).

As mesmas autoras argumentam que o quadrilátero da formação - ensino, serviço, gestão e controle social (CECCIM; FEUERWERKER, 2004) -, o engajamento dos gestores, a Educação Permanente em Saúde como tópico de qualificação da Atenção Primária e a existência de equipamentos de EPS - escolas de saúde pública e as escolas técnicas -, também favorecem a implementação da PNEPS.

Porém, por outro lado, alguns fatores se tornam obstáculos para a PNEPS. Entre eles estão a interrupção do repasse de recursos, pelo Governo Federal, desde 2011 e o desalinhamento conceitual acerca da teoria e das práticas que envolvem a Educação Permanente em Saúde. Ainda, podem ser mencionadas as dificuldades que envolvem a execução dos recursos financeiros e o monitoramento e avaliação das ações de EPS. "Essa falta de compreensão por parte dos gestores, dos servidores, de todos os objetivos e propostas da política, que é muitas vezes confundida e pensam se tratar de apenas cursos e cursos. Isso é um desafio". (SILVA, 2020, p. 7).

Já que a promoção da saúde surgiu como um marco norteador da Saúde Pública, o qual vem, ao longo do tempo, evoluindo como um modelo de ações em saúde, o educador, no contexto da EPS, utiliza-se de diversas ferramentas e formas pedagógicas de aprendizado para expor um determinado assunto ou para desenvolver ações aos ouvintes que sejam significativas e positivas no que se refere ao fortalecimento da saúde.

É fato, que a educação é uma ferramenta primordial para prevenir doenças e promover saúde, pois ela desenvolve o conhecimento e instiga o pensamento reflexivo sobre hábitos de vida que auxiliam a saúde. Assim, as ações realizadas, em geral, possuem um público pré-determinado, uma temática a ser trabalhada, 
além de diferentes profissionais como protagonistas no processo de educação em saúde, como médico, enfermeiro, agente de saúde, entre outros profissionais. Ademais, a educação em saúde, por vezes, está estreitamente relacionada à atenção primária, sendo uma das atribuições do Ministério da Saúde na Política Nacional de Atenção Básica, a Unidade Básica de Saúde (UBS), por meio de Estratégias de Saúde da Família (ESF) visam promover ações educativas nas comunidades.

Nesse contexto, dentre as ações já realizadas e que possuem um impacto positivo na sociedade estão palestras abordando doenças virais e bacterianas, cuidados com o período gestacional, temas como prevenção de doenças sexualmente transmissíveis, gravidez na adolescência, tuberculose, prevenção ao suicídio, alimentação saudável, prevenção de câncer de mama. Dessa forma, o profissional se caracteriza como um indivíduo que realiza a construção do conhecimento técnico-científico, mas aliando os saberes empíricos dos ouvintes, a fim de que ocorra a geração de conhecimento ou pensamento reflexivo, ou seja, o fornecimento de informação é capaz de gerar um empoderamento social.

Outro ponto de impacto positivo da educação em saúde é o fato de que, ordinariamente, o envelhecimento da população vem ocorrendo, e ele gera modificações biopsicossociais no indivíduo. Assim, já se observa profissionais da saúde inseridos em promover a saúde nessa faixa etária da vida, a fim de que um envelhecimento saudável, ativo, com diminuição da vulnerabilidade e riscos à saúde seja preconizado a essas pessoas.

Tais movimentos se tornam potentes tendo em vista que, ao mesmo tempo em que a ideia de educação em saúde fortalece, positivamente, dinâmicas individuais e comunitárias, por meio de práticas de escuta, envolvimento e ação, a PNEPS capacita e profissionais e gestores para tanto. É fundamental que haja um alinhamento conceitual e prático a partir das políticas públicas de educação e de saúde brasileiras. 


\section{CONSIDERAÇÕES FINAIS}

É possível inferir que a estruturação da PNEPS e das políticas a ela relacionadas exigiram e ainda exigem uma grande mobilização no ponto de vista operacional, com isso, é válido ressaltar que ainda existem dificuldades a serem superadas para a efetiva implementação e para a obtenção de resultados mais promissores no que diz respeito ao objetivo primordial de aprimorar os serviços de saúde no país.

As práticas de Educação em saúde são imprescindíveis e complementares para a garantia de manutenção de qualidade dos serviços do SUS, e promoção de indicadores sociais de saúde cada vez melhores. Os elementos que favorecem, os que dificultam e os que podem fortalecer a implementação da PNEPS integram, de maneira geral, um mesmo conjunto que inclui os temas: financiamento; apoio técnico; integração institucional; articulação em redes regionais e colegiadas; e alinhamento conceitual.

Tais temas também foram relacionados no estudo que apresenta os resultados do ciclo de oficinas, com representantes das diversas instituições envolvidas no planejamento, programação, execução e avaliação das ações de EPS, ocorrido no bojo do processo de retomada da PNEPS.

Portanto, as ações realizadas a partir das PNEPS possuem inúmeros pontos positivos, tanto para quem recebe essas ações, quanto para quem as repassa, a exemplo a forma coletiva das ações realizadas, demonstrando o apoio e a união de diferentes profissionais que buscam passar seu conhecimento ao próximo, a fim de que ocorra uma educação permanente em saúde. E, em contrapartida, a população alvo da política de educação recebe um conhecimento capaz de melhorar sua qualidade de vida, prevenir enfermidades e gerar mudanças de comportamento em relação à saúde através da construção de uma nova reflexão ou um novo saber. 


\section{REFERENCIAS}

BRASIL. Ministério da Saúde. Secretaria de Gestão do Trabalho e da Educação na Saúde. Departamento de Gestão da Educação na Saúde. Política Nacional de Educação Permanente em Saúde: o que se tem produzido para o seu fortalecimento? / Ministério da Saúde, Secretaria de Gestão do Trabalho e da Educação na Saúde, Departamento de Gestão da Educação na Saúde - 1. ed. rev. - Brasília : Ministério da Saúde, 2018. Disponível em: <https://bvsms.saude.gov.br/ bvs/publicacoes/politica_nacional_educacao_permanente_saude_fortalecimento.pdf.> Acesso em 03 de novembro de 2021.

CARDOSO, M. L. M. et al. A Política Nacional de Educação Permanente em Saúde nas Escolas de Saúde Pública: reflexões a partir da prática. Ciência \& Saúde Coletiva [online]. 2017, v. 22, n. 5 Acesso em: 14 Junho 2021, pp. 1489-1500. Disponível em: <https://doi.org/10.1590/1413-81232017225.33222016>.

CECCIM, RB; FEUERWERKER, LCM. O quadrilátero da formação para a área da saúde: ensino, gestão, atenção e controle social. Physis. 2004; 14(1):41-65. Disponível em: https://www.scielo.br/j/physis/a/GtNSGFwY4hzh9G9cGgDjqMp/?format=pdf\&lang=pt. Acesso em: 03 de novembro de 2021.

CONCEIÇÃO, Dannicia Silva et al. A Educação em Saúde como Instrumento de Mudança

Social. Braz. J. of Develop.,Curitiba, v. 6, n. 8, p. 59412-59416 aug. 2020. DOI:10.34117/bjdv6n8-383. Acesso em: 20 de junho de 2021. Disponível em: <https://www.brazilianjournals.com/index.php/BRJD/article/view/15195.>

CORREAA, Aline Bússolo. Política Nacional de Educação Permanente em Saúde: Diferença Entre suas Portarias Instituintes. $17^{\circ}$ Seminário Nacional de Pesquisa em Enfermagem - SENPE, Natal, RN, jun. 2013. Disponível em: <http:// www.abeneventos.com.br/anais_senpe/17senpe/pdf/1429po.pdf.>. Acesso em: $12 / 06 / 2021$

FALKENBERG, Mirian Benites et al. Educação em saúde e educação na saúde: conceitos e implicações para a saúde coletiva. Ciência \& Saúde Coletiva [online]. 2014, v. 19, n. 03 [Acessado 15 Junho 2021] , pp. 847-852. Disponível em: <https://doi.org/10.1590/1413-81232014193.01572013>. ISSN 1678-4561. 
FEUERWERKER, LCM. Gestão dos processos de mudanças na graduação em medicina. In: Marins JJN, Rego S, Lampert JP, organizadores. Educação médica em transformação: instrumentos para a construção de novas realidades. São Paulo: Hucitec; 2004. p. 17-39.

FERRAZ, L.; et al. Educação Permanente na Enfermagem: uma revisão integrativa. Revista Baiana de Enfermagem, Salvador, v. 28, n. 2, p. 196-207, maio/ago. 2014. Disponível em: <https://periodicos.ufba.br/index.php/enfermagem/article/ view/8366>. Acesso em 03 de novembro de 2021.

FRANÇA, T.; et al. A capilaridade da Política Nacional de Educação Permanente em Saúde no Brasil. Atas CIAIQ 2016: Investigação Qualitativa em Saúde, v. 2, 2016. Disponível em: <https://proceedings.ciaiq.org/index.php/ciaiq2016/article/ view/738>. Acesso em 03 de novembro de 2021.

FRANÇA, Tania; et al. Limites e possibilidades das comissões permanentes de integração ensino-serviço: percepções dos gestores. Saúde Debate. Rio de Janeiro, V. 41, N. ESPECIAL 3, P. 144-154, Set 2017. DOI: 10.1590/0103-11042017S311. Disponível em: <https://www.scielo.br/j/sdeb/a/SygBGrdNbL6VB59NxykvWDn/?format=pdf\&lang=pt.> Acesso em 03 de novembro de 2021.

GONÇALVES, Romário de Sousa et al. Educação em saúde como estratégia de prevenção e promoção da saúde de uma unidade básica de saúde. Braz. J. Hea. Rev., Curitiba, v. 3, n. 3, p. 5811-5817 may./jun. 2020. DOI:10.34119/bjhrv3n3-144. Acesso em: 15 de julho de 2020. Disponível em: <https://www.brazilianjournals.com/index.php/BJHR/article/view/11122.>

MINISTÉRIO DA SAÚDE. Portaria N 1.996, de 20 de agosto de 2007. Disponível em: <https://bvsms.saude.gov.br/bvs/saudelegis/gm/2007/prt1996_20_08_2007. html.> Acesso em: 03 de novembro de 2021.

MACÊDO, N. B et al. O desafio da implementação da educação permanente na gestão da educação na saúde. Trabalho, Educação e Saúde, v. 12, n. 2, p. 379-401, 2014. Disponível em: <https://www.scielo.br/j/tes/a/3PWLyg7mL9s8XrCkbKWjtkH/abstract/?lang=pt.> Acesso em: 03 de novembro de 2021. 
MALLMANN, DG et al. Educação em saúde como principal alternativa para promover a saúde do idoso. Ciência \& Saúde Coletiva, 20(6):1763-1772, 2015. DOI: 10.1590/1413-81232015206.02382014. Disponível em: <https://www.scielo.br/j/ csc/a/MQYsHjXzsJfwNgwfKrGVcfp/abstract/?lang=pt.> Acesso em: 20 de junho de 2021.

NICOLETTO, S. C. S.; et al. Desafios na implantação, desenvolvimento e sustentabilidade da Política de Educação Permanente em Saúde no Paraná, Brasil. Saúde e Sociedade, São Paulo, v. 22, n. 4, p. 1094-1105, 2013. Disponível em: <https://www.scielo.br/j/sausoc/a/sr5gFQK46ytV5tYsXgXMZGw/abstract/?lan$\mathrm{g}=\mathrm{pt}$. Acesso em 03 de novembro de 2021.

NUNES, Vanessa Larisse Soares et al. A importância da educação em saúde como forma de prevenção ao câncer de mama: um relato de experiência em uma unidade básica de saúde de Palmas/TO. Revista Extensão - 2020 - v.4, n.2. Disponível em: <https://revista.unitins.br/index.php/extensao/article/view/4219.> Acesso em: 20 de junho de 2021.

RIOS, C. T. F. \& Vieira, N. F. C. Ações educativas no pré-natal: reflexão sobre a consulta de enfermagem como um espaço para educação em saúde. Ciência \& Saúde Coletiva, 12(2):477-486, 2007. Disponível em: <https://www.scielo.br/j/csc/a/HDzzLTnLSG4KfLmTZxJRdbH/abstract/?lang=pt.> Acesso em: 20 de junho de 2021.

SILVA CBG, Scherer MDA. A implementação da Política Nacional de Educação Permanente em Saúde na visão de atores que a constroem. Interface (Botucatu). 2020; 24: e190840 https://doi.org/10.1590/Interface.190840. Disponível em: <https://www.scielo.br/j/icse/a/wSmkML5zgMkhhS8WmRYsKpm/abstract/?lan$\mathrm{g}=$ pt.>Acesso em: 03 de novembro de 2021. 


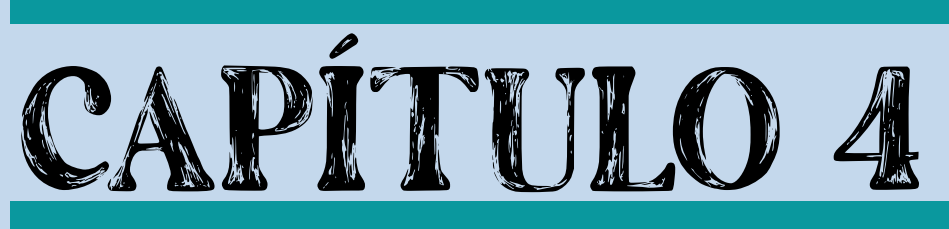

\title{
HIV E AIDS: EDUCAÇÃO EM SAÚDE A SERVIÇO DA QUALIDADE DE VIDA
}

\author{
Laura Schmidt Rizzi \\ Jordana Carolina Weiss \\ Silvana Born Behling
}




\section{INTRODUÇÃO}

A "Educação em Saúde" traz em sua atuação a intenção de empoderar a população quanto às diferentes necessidades nos mais amplos contextos, visando alcançar demandas após perceber potencialidades e fraquezas - o que permite maior acesso da população às suas carências, sendo essencial no contexto das políticas públicas. Nessa perspectiva, a criação da Secretaria de Gestão do Trabalho e da Educação na Saúde (SGTES) em 2003, um dos destaques do Sistema Único de Saúde (SUS), denota-se como marco para a garantia de uma Política Nacional de Recursos Humanos em Saúde. Através dela, a educação na saúde adquiriu novo caráter nacional.

É nesse sentido que se observa educação e saúde como práticas intrinsecamente correlacionadas, em que são produzidos, aplicados e compartilhados conhecimentos que são puramente objetos destinados ao bem estar dos seres humanos (PAES, 2016). Evidencia-se, ainda, que as ações de saúde promovidas por meio de políticas públicas nos diferentes níveis de atenção à saúde não apenas dependem de raciocínio clínico, de diagnóstico, de prescrição de cuidados e de avaliação da terapêutica, mas de uma soma de fatores externos que envolvem, também, a prática educativa. Assim, são essenciais processos de intervenção que promovam melhor estado de saúde para o indivíduo e para a coletividade, que envolvem fatores orgânicos, psicológicos, socioeconômicos e espirituais (PEREIRA, 2003).

Nesse sentido, o documento "Vivendo Posithivamente: Cartilha educativa para promoção da saúde e qualidade de vida de pessoas que vivem com HIV/ Aids" (JESUS; REIS, 2017) em seu volume 3, especifica como seguir em frente após o diagnóstico, por meio métodos de comunicação e de informação com o seu público alvo - adultos que vivem com HIV e AIDS. Através de uma prática educativa clara e simples - como toda boa ação voltada ao público leigo deve ser -, a cartilha possibilita aos indivíduos que vivem com HIV e AIDS um acesso didático a diversas informações. 
Sabe-se que houve grande evolução no que se compreende de políticas públicas referentes à HIV e AIDS; entretanto, o diagnóstico e a agnição acerca do tema para aqueles que convivem com elas não é simples e, muito menos, deve ser deixado de lado. O estigma e a discriminação contra todas as pessoas que vivem com HIV e AIDS desencorajam-nas a aprender acerca de seu estado de saúde, de adotar comportamento preventivo, de seguir as intervenções propostas pela equipe de saúde e de iniciar o tratamento de supressão virológica (WHO 2020). Dessa maneira, buscar através das ações educativas um meio de alcançar melhor índices acerca do tema HIV e AIDS, seus impactos sociais e suas consequências na vida dos indivíduos soropositivos é essencial.

\section{EMBASAMENTO TEÓRICO}

A educação e a saúde são espaços de produção e aplicação de saberes e conhecimentos destinados ao desenvolvimento humano (PAES, 2016). É consenso o papel de ações de promoção da saúde e de educação em saúde promovidas e desenvolvidas para garantir a formação integral de profissionais, sendo a reflexão sobre Educação em Saúde um agente relevante na observação de inúmeros aspectos importantes que garantem melhor assistência de saúde à população (PAES, 2016) .

Assim, pode-se dizer que Educação em Saúde corresponde a um recurso que proporciona produção de conhecimento científico com intermédio de profissionais impactando na vida cotidiana dos demais indivíduos. Essas práticas envolvem três atores: os profissionais da saúde, através de prevenção e promoção de saúde; os gestores, por meio do apoio a esses profissionais; e a população, que necessita construir seus conhecimentos e aumentar sua autonomia nos cuidados, individual e coletivamente (PAES, 2016).

Conforme demonstram França e Magnago (2019) por meio da SGTES, a educação na saúde constituiu-se como uma política de Estado. Assim, foi possível o planejamento e estabelecimento de iniciativas relacionadas à reorientação da formação profissional e à educação permanente dos trabalhadores da saúde. 
Ademais, Educação em Saúde é uma estratégia de promoção da saúde que não se limita a eliminar a doença: é um processo constante que visa sempre melhorar as condições atuais. Afere-se que, caso feita de forma ampliada, por meio de políticas públicas e com a reordenação de serviços para além de meros tratamentos clínicos, englobará práticas pedagógicas que promoverão liberdade, orientando-se para ações cuja essência está na melhoria da qualidade de vida (SCHALL, 2012). Portanto, a Educação em Saúde torna-se efetiva ao dar aos indivíduos a capacidade de desenvolver uma visão crítica dos problemas e agir junto com os profissionais para saná-los.

\section{METODOLOGIA}

O presente estudo teve como base metodológica a análise documental que consiste em identificar, verificar e apreciar os documentos com uma finalidade específica (SOUZA, 2011). Essa modalidade de pesquisa tem a abordagem qualitativa como característica, dado que os estudos qualitativos se caracterizam como aqueles que buscam compreender um fenômeno em seu ambiente natural, definindo-se como principal agente o investigador que trabalha na obtenção de informações (ALVES, 2021). Desse modo, a análise documental tem como ponto alvo a capacidade do pesquisador de selecionar, tratar e interpretar a informação, visando compreender a relação com o seu objetivo de pesquisa (KRIPKA, 2015).

A partir disso, para esse trabalho foram realizadas buscas na internet com o objetivo de encontrar uma cartilha que fosse a referência base para o seguinte trabalho. Disso em diante, encontrou-se o site Grupo de Pesquisa da Escola de Enfermagem de Ribeirão Preto da Universidade de São Paulo. Nele há diversas cartilhas as quais orientam a população adulta que vive com HIV e AIDS sobre as perspectivas dessas condições, além de descrever situações que envolvem esses aspectos. $O$ site apresenta 5 cartilhas que abordam os assuntos: cuidando do corpo (volume 1), cuidando do corpo e da mente (volume 2), seguindo em frente (volume 3), buscando novos horizontes (volume 4) e abraçando meus direitos (volume 5); dentre estas opções escolheu-se através de uma análise 
documental o volume 3 para ser discutido no atual trabalho. Ele foi escrito pelas autoras Giselle Juliana de Jesus e Renata Karina Reis, no ano de 2017, contendo 46 páginas e abordando conteúdos referentes ao enfrentamento do diagnóstico, às modificações proporcionadas às pessoas portadoras do vírus, além de enfatizar as questões referente à adesão do tratamento; para isso, os conteúdos são divididos em tópicos buscando clareza e didática. A linguagem da cartilha é de fácil entendimento e bastante ilustrativa, a fim de proporcionar maior compreensão aos leitores.

\section{DISCUSSÃO}

O documento "Vivendo Posithivamente: Cartilha educativa para promoção da saúde e qualidade de vida de pessoas que vivem com HIV/Aids", em seu volume 3 (Seguindo em frente) aborda formas de entendimento e de enfrentamento do indivíduo com HIV e AIDS durante e após o seu diagnóstico. Ainda, é interessante perceber que ele é destinado a adultos que vivem com HIV e AIDS e que - ao longo de sua extensão - estão presentes caixas de texto coloridas com orientações sinalizadas: 1) em verde, apontando uma recomendação que deve ser seguida para melhorar a qualidade de vida; 2) em amarelo, chamando a atenção para informações importantes; e 3) em vermelho, direcionando orientações para reflexão.

O diagnóstico de infecção por HIV traz consigo muitos conflitos para a pessoa que o recebe, uma vez que a convivência com uma doença crônica exige mudanças de hábitos para que o tratamento seja efetivo e ofereça uma qualidade de vida adequada para esse portador (WAIDMAN, 2011). Para esse contexto é preciso que o paciente entenda sobre os fatores de risco que a infecção por HIV pode provocar, sobre a importância de uma periodicidade em dosagens de carga viral e de células TCD4+, além de consciência da importância de comparecer ao médico que acompanha o seu caso (GOMES, 2011). É doloroso receber esse diagnóstico e com ele vêm muitas incertezas e dúvidas; por isso, é essencial que 
o portador de HIV divida-o com pessoas que ele tenha confiança e proximidade (OLIVEIRA, 2013). Para esse contexto, o alerta que a Cartilha traz para as pessoas que vivem com a soropositividade do HIV é muito importante ("não se isole, essa não é a melhor saída"), uma vez que indica para essas pessoas que o distanciamento no âmbito social pode agravar futuras complicações.

Considera-se que não há uma regra no que se refere a quem deve ser comunicado sobre o resultado dos testes e estado de saúde, pois é uma decisão particular, sendo direito do paciente realizar esse contato (WAIDMAN, 2011); entretanto, essa decisão não deve interferir no estado de saúde de outras pessoas (JESUS; REIS, 2017). Dessa forma, o que o profissional que acompanha esse paciente deve fazer é estimular que o portador de HIV e AIDS divida esse diagnóstico com pessoas em quem tenha segurança (WAIDMAN, 2011). Nesse sentido, o documento abordado traz a família como sendo peça fundamental no apoio que o portador de infecção por HIV pode receber - considerando-a não somente no sentido conservador, mas em todos novos conceitos do que a constitui hoje em dia. Portanto, as autoras na Cartilha afirmam que o enfrentamento do diagnóstico não deve ser um processo solitário e sem perspectivas, mas sim com novas oportunidades para seguir em frente mudando hábitos e apoiando-se em pessoas que tornam esse processo mais tranquilo.

Cabe destacar que é essencial, caso haja alguma parceria sexual (fixa ou casual), que seja realizada uma conversa em que se comunique a condição sorológica. Contudo, quando o indivíduo não encontra em seus vínculos sociais o suporte necessário, grupos de adesão e ONGs para pessoas que vivem com HIV e AIDS costumam ser boas opções (JESUS; REIS, 2017). Por meio deles, pode-se haver trocas de experiências em grupo, além de que desenvolve-se um contato mais estreito com os profissionais da saúde, o que possibilita que esse indivíduo seja melhor conduzido pelos serviços de referência. Sabe-se, então, que o manejo adequado desse apoio fornecido pode promover benefícios mú- 
tuos na rede, uma vez que a conexão social garante o bem-estar desses indivíduos (LAVEZZO, 2019).

Seguindo esse viés proposto pela Cartilha, a equipe de saúde deve ter a habilidade de escutar, compreender e compartilhar decisões com o paciente, dado que essa conduta proporciona um suporte terapêutico e autonomia a ele. Assim, pode-se perceber que o documento passa a nortear a formação profissional avessa a uma visão simplista biologicista mas focada no ensino em saúde próximo das necessidades sócio-históricas da população (OLIVEIRA, 2013). Ainda, o paciente pode apoiar-se em sua espiritualidade, dado sua intrínseca relação com a saúde (especialmente mental, e consequente, global) e sua classificação inerente à humanidade. Podendo ser definida como organização complexa de crenças que enfoca em elementos específicos, transmitindo significado e vitalidade, a espiritualidade promove a melhoria da relação consigo mesmo e com o outro, ressignificando conceitos e auxiliando indivíduos a encararem suas realidades de uma forma mais leve e esperançosa (SAAD, 2001). Por outro lado, a religiosidade tem ligação mais potente com os sentidos de vida e de morte e alta dependência de aceitação de determinados valores e rituais, mas pode igualmente possibilitar ao indivíduo maior força para lidar com problemas emocionais e físicos, costumando ter estilos de vida mais saudáveis (SAAD, 2001).

Logo, destaca-se a importância da aceitação da doença - ampliando o mero conceito diagnóstico, dado que o indivíduo não se resume a ele -, sendo os métodos de enfrentamento e de superação das dificuldades não tão relevantes quanto de fato encontrar a tranquilidade de continuar conquistando saúde e bem estar na busca por qualidade de vida. Cabe ressaltar, então, a importância do preparo dos profissionais em conseguir suprir a demanda desses pacientes no que tange à relação saúde-espiritualidade-religiosidade.

“(...) pela importância crescente dedicada à correlação entre saúde, espiritualidade e religiosidade, médicos e demais profissionais da saúde deveriam estar preparados para atenderem as demandas espirituais e religiosas de seus pacientes, adquirindo informação e treinamento 
nos diversos aspectos e abordagens desse vasto campo de conhecimento (TEIXEIRA, 2020)."

Conforme citado na cartilha em relação ao tratamento das pessoas que vivem com o HIV e AIDS, é sabido que o uso dos antirretrovirais levou a um declínio relevante da morbidade e da mortalidade relacionadas a essa infecção, além do aumento da expectativa de vida dessa população. Em uma década, houve uma intensa melhora na combinação dos antirretrovirais, o que tornou o HIV uma doença crônica com possibilidades de controle (POLEJACK, 2010). No Brasil, entre as estratégias para combater essa epidemia, destaca-se a política de distribuição universal e gratuita dos medicamentos antirretrovirais aos portadores do HIV e AIDS que necessitem de tratamento.

A Cartilha destaca que o tratamento jamais deve ser interrompido por causa dos efeitos colaterais, dentre os quais, podemos destacar os efeitos agudos como náusea, vômito, diarreia, cefaleia, sonolência e falta concentração, rash cutâneo, disfunção hepática, reações alérgicas; além de efeitos a longo prazo como alterações hematológicas e metabólicas, dislipidemia, alteração glicose, perda mineral óssea, lipodistrofia, alteração renal e cardiovascular. Praticamente todas as medicações antirretrovirais (ARVs) têm efeitos colaterais, mas nem todas as pessoas que as utilizam irão apresentar o mesmo efeito adverso ou na mesma proporção, na maioria dos casos estes efeitos são leves e bem tolerados (BRASIL, 2017). Dentre os medicamentos mais recentemente incorporados ao SUS para tratamento do HIV e AIDS estão o esquema de dose fixa combinada de Tenofovir, Lamivudina e Efavirenz, que apresenta reações adversas descritas como tontura, insônia e náuseas, e o Dolutegravir, ao qual podem ser comuns náuseas, diarreia e cefaleia. Os ARVs atuam por meio da inibição da replicação viral ou da entrada do vírus na célula do hospedeiro, para reduzir a quantidade do HIV, também denominada carga viral, para menos de 50 partículas $/ \mathrm{mL}$ de sangue, o que caracteriza carga viral indetectável (BRASIL, 2017). 
Ademais, existem algumas estratégias para ajudar quem convive com HIV e AIDS a melhorar a adesão ao tratamento. Entre elas, a Cartilha aborda a importância que os remédios prescritos sejam ingeridos no horário e dosagem correta, previamente combinados com o médico. Uma estratégia interessante para não esquecer de tomar os antirretrovirais é estabelecer uma rotina diária, para isso podem ser usados relógios despertadores. Vale destacar que o Ministério da Saúde tem um aplicativo para facilitar a adesão de pacientes ao tratamento chamado "Viva Bem". Esse aplicativo tem a função de lembrar o usuário quando é preciso medicar-se ou buscar seu medicamento nos serviços de saúde. Além disso, o aplicativo "Viva Bem" está disponível para download gratuito. Dessa forma, a adesão do tratamento é muito importante, uma vez que o uso dos antirretrovirais é necessário para quem vive com HIV e AIDS alcançar a longevidade e a qualidade de vida.

\section{COMENTÁRIOS FINAIS}

Em suma, o trabalho apresenta diversos vieses em que se pode auxiliar as pessoas que vivem com HIV e AIDS a buscar uma qualidade de vida melhor, tanto no que se refere ao psicossocial quanto no controle viral em si. Sabe-se, ainda, que o enfrentamento do diagnóstico é algo necessário e que o assunto deve ser levado com seriedade pelos profissionais que amparam esse indivíduo, assim como foi demonstrado e exemplificado na Cartilha.

Através da Cartilha e de seu métodos de Educação em Saúde supracitados, percebe-se a importância de abordagens que se embasem em conhecimentos biopsicossociais e de profissionais que visualizem o paciente para além de sua sua condição clínica, promovendo saúde através de ações práticas de empatia e não de teorias baseadas no binômio saúde vs doença. Ainda, com vistas a diminuir o estigma e pontuar a possibilidade de diminuição da carga viral e cura, percebe-se a redução da utilização dos termos HIV e AIDS de forma conjunta apenas separados por barra e ou através de letras minúsculas. Desse modo, 
pode-se, inclusive, destacar a atualização percebida acerca dos termos utilizados pela Cartilha como uma experiência da educação transformando a saúde - e vice-versa.

\section{REFERÊNCIAS}

ALVES, Laís Hilário et al. Análise documental e sua contribuição no desenvolvimento da pesquisa científica. Cadernos da FUCAMP, v. 20, n. 43, 2021. Disponível em http://www.fucamp.edu.br/editora/index.php/cadernos/article/view/2335, acesso em 17/06/2021.

BRASIL. Ministério da Saúde. Secretaria de Vigilância em Saúde. Protocolo Clínico e Diretrizes Terapêuticas para o Manejo da Infecção pelo HIV em Adultos. Brasília, 2017. Disponível em http://www.aids.gov.br/pt-br/pub/2013/protocolo-clinico-e-diretrizes-terapeuticas-para-manejo-da-infeccao-pelo-hiv-em-adultos, acesso em 17/06/2021.

DE OLIVEIRA, Danielle Abrantes. Envelhecendo com HIVIAIDS: história de lutas e desafios. 2013. Disponível em https://repositorio.ufpb.br/jspui/bitstream/ tede/5130/1/arquivototal.pdf, acesso em 17/06/2021.

DE SOUZA, Jacqueline; KANTORSKI, Luciane Prado; LUIS, Margarita Antonia Villar. Análise documental e observação participante na pesquisa em saúde mental. Revista Baiana de Enfermagemí, v. 25, n. 2, 2011. Disponível em <https:// periodicos.ufba.br/index.php/enfermagem/article/view/5252/4469>, acesso em 17/06/2021.

FRANÇA, Tania; MAGNAGO, Carinne. Políticas, programas e ações de educação na saúde: perspectivas e desafios. 2019. Disponível em https://www.scielo. br/j/sdeb/a/5jKqsspWjmvRKRhYz7LYTFP/?lang=pt, acesso em 17/06/2021.

GOMES, Antonio Marcos Tosoli; SILVA, Érika Machado Pinto; OLIVEIRA, Denize Cristina de. Representações sociais da AIDS para pessoas que vivem com HIV e suas interfaces cotidianas. Revista Latino-Americana de Enfermagem, v. 19, n. 3, 2011. Disponível em https://www.scielo.br/j/rlae/a/mTjQkvHgjbRhBX8K7yXvPgL/ abstract/?lang=pt, acesso em 17/06/2021. 
JESUS, Giselle Juliana; REIS, Renata Karina. Vivendo Posithivamente: Cartilha educativa para promoção da saúde e qualidade de vida de pessoas que vivem com HIVIAids. Ribeirão Preto-SP: FIERP, 2017. Volume 3, Seguindo em frente. Disponível em http://gruposdepesquisa.eerp.usp.br/sites/cartilha-arquivos/pdf/3. pdf, acesso em 17/06/2021.

KRIPKA, Rosana Maria Luvezute; SCHELLER, Morgana; BONOTTO, Danusa de Lara. Pesquisa documental na pesquisa qualitativa: conceitos e caracterização. Revista de investigaciones UNAD, v. 14, n. 2, p. 55-73, 2015. Disponível em https://core.ac.uk/download/pdf/322589335.pdf, acesso em 17/06/2021.

LAVEZZO, Fernanda et al. Caracterização da rede de apoio psicossocial dos pacientes soropositivos. Arquivos de Ciências da Saúde, v. 26, n. 2, p. 94-98, 2019. Disponível em https://fi-admin.bvsalud.org/document/view/ze543, acesso em 17/06/2021.

OLIVEIRA, Inajara Carla; BALARD, Cíntia Reis; CUTOLO, Luiz Roberto Agea. Formação profissional em saúde: integralidade em perspectiva. Saúde \& Transformação Social/Health \& Social Change, v. 4, n. 1, p. 69-72, 2013. Disponível em http://incubadora.periodicos.ufsc.br/index.php/saudeetransformacao/article/ view/1977, acesso em 17/06/2021.

PAES, Caila Carolina Duarte Campos. A importância da abordagem da educação em saúde: revisão de literatura. Petrolina-PE, vol. 6, n.11, p.80-90. 2016. Disponível em https://www.periodicos.univasf.edu.br/index.php/revasf/article/ view/38/45, acesso em 17/06/2021.

PEREIRA, A. L. F. As tendências pedagógicas e a prática educativa nas ciências da saúde. Cad. Saúde Pública, v. 19, n. 5, p. 1527-1534, 2003. Disponível em https://www.scielo.br/j/csp/a/Jj6qF3CWvsZMfdNRC8GzyvH/abstract/?lang=pt, acesso em 17/06/2021.

POLEJACK L, SEIDL EMF. Monitoramento e avaliação da adesão ao tratamento antirretroviral para HIV/Aids: desafios e possibilidades. Ciência Saúde Colet [internet]. 2010. Disponível em http://www.scielo.br/scielo.php?script=sci_arttext\&pid=S1413-81232010000700029\&lng=e, acesso em 17/06/2021.

SAAD, Marcelo; MASIERO, Danilo; BATTISTELLA, Linamara Rizzo. Espiritualidade baseada em evidências. Acta Fisiátrica, v. 8, n. 3, p. 107-112, 2001. Disponível em https://www.revistas.usp.br/actafisiatrica/article/view/102355/100673, acesso em 17/06/2021. 
SCHALL, Virgínia T.; STRUCHINER, Miriam. Educação em saúde: novas perspectivas. Editorial, Núcleo de Tecnologia Educacional para a Saúde. Rio de Janeiro. 2012. Disponível em https://www.scielo.br/j/csp/a/McP6pRbyPGYyWjjLzgr5LJn/?lang=pt\&format=pdf, acesso em 17/06/2021.

TEIXEIRA, Marcus Zulian. Interconexão entre saúde, espiritualidade e religiosidade. Revista de Medicina, v. 99, n. 2, p. 134-147, 2020. Disponível em https:// www.revistas.usp.br/revistadc/article/view/149273, acesso em 17/06/2021.

WAIDAMAN, Maria Angélica Pagliarini; BESSA, Jacqueline Botura; DA SILVA, Fernanda Lorena Canton. Viver com AIDS e sofrer psiquicamente. Revista Rene. Fortaleza, v.12, Jan-mar. 2011. Disponível em https://www.redalyc.org/ pdf/3240/324027974023.pdf, acesso em 17/06/2021.

WORLD HEALTH ORGANIZATION. Consolidated HIV strategic information guidelines: Driving impact through programme monitoring and management. April, 2020. Disponível em https://www.who.int/publications/i/item/9789240000735, acesso em 17/06/2021. 




\title{
DETERMINANTES SOCIAIS E A
} IMPORTÂNCIA DA EDUCAÇÃO EM SAÚDE NA PREVENÇÃO DA SÍFILIS CONGÊNITA

\author{
Amanda Hillesheim Schuck \\ Bernardo Duarte Tomazi \\ Carolina Tisott Burtet
}




\section{INTRODUÇÃO}

Esse texto tem por objetivo discutir o número de nascimentos de crianças com sífilis no Brasil e relacionar o impacto da educação e de determinantes sociais na saúde da mulher e de recém-nascidos. A ideia surgiu a partir de aulas práticas na disciplina de Pediatria na Unidade de Internação Obstétrica do Hospital Geral de Caxias do Sul (SUS), onde visualizamos uma grande quantidade de recém-nascidos contaminados por sífilis e outras doenças infecto contagiosas. Ferezin, Bertolini e Demarchi (2012) afirmam que, no país, a qualidade do atendimento à gestante realizada pelo Sistema Único de Saúde (SUS) é de extrema importância na atenção obstétrica e neonatal. Com o objetivo de garantir o nascimento de uma criança saudável e de promover o bem-estar materno e fetal, estão inclusos na atenção pré-natal alguns exames laboratoriais que detectam doenças que podem gerar riscos gestacionais, entre eles, o rastreio para sífilis, hepatite B, HIV e toxoplasmose, além da sorologia para rubéola se existirem sintomas sugestivos.

É importante destacar que a identificação da doença nos três primeiros meses da gestação e o tratamento adequado impedem a transmissão da sífilis da mãe para o bebê. Silva et al. (2015, citando PADMAVATHY et al, 2013) colocam que, no Brasil, doenças infecciosas durante a gestação são, de modo geral, frequentes, e afetam principalmente populações menos favorecidas. Além disso, de acordo com Domingues et al (2012, apud SILVA et al, 2015) discutem que, quanto maior o número de consultas de pré-natal, menor o número de desfechos desfavoráveis durante a gravidez. Segundo ele, uma das justificativas para uma menor procura pelo atendimento pré-natal em determinadas mulheres seria a baixa escolaridade. Tendo em vista esse cenário, abordaremos uma discussão centrada na influência dos determinantes sociais e da educação sobre a saúde desse grupo. 


\section{SÍFILIS CONGÊNITA NO BRASIL: CONTEXTUALIZAÇÃO}

De acordo com uma notícia publicada pelo Instituto de Pesquisa e Ensino em Saúde Infantil (PENSI) em março de 2020, o Boletim Epidemiológico: Vigilância em Saúde no Brasil de 2003-2019 mostrou que, entre 2003 e 2017, houve um aumento da taxa de incidência de sífilis congênita de 1,7 para 8,6 casos por mil nascidos vivos. Ou seja, no ano de 2017, a taxa de recém-nascidos com a doença foi 5 vezes maior que em 2003. Além disso, outra informação importante é a taxa de detecção da doença em gestantes, que passou de 0,5 para 17,2 casos por mil nascidos vivos no período de 2005 a 2017 (INSTITUTO PENSI, 2020). Ademais, em dados mais recentes, o Boletim Epidemiológico de Sífilis de 2020 mostra que, em gestantes, foram registrados 61.127 casos em 2019, com redução de 3,3\% em relação ao ano anterior (63.182 casos), mas que uma possível explicação dessa redução pode estar relacionada ao atraso na notificação/ atualização de dados devido à mobilização dos profissionais voltada ao controle da pandemia da Covid-19 (MINISTÉRIO DA SAÚDE, 2020).

Ainda nessa linha de pensamento, para termos uma visão mais próxima dessa realidade, o Boletim Epidemiológico da Sífilis 2020, organizado pelo Ministério da Saúde, revela que o Rio Grande do Sul é o segundo Estado com a taxa de detecção mais elevada da doença e os dados mostram que, no ano passado, o RS registrou 5.284 casos de sífilis adquirida e 1.564 de sífilis congênita. Tendo isto em vista, coletamos dados no Hospital Geral de Caxias do Sul sobre o número de nascimentos e o número de recém-nascidos em tratamento para sífilis congênita entre os meses de janeiro-agosto de 2021, e obtivemos uma relação de 35,97 infectados a cada mil nascimentos - o que realmente confirma uma alta incidência em uma das grandes cidades do estado. Entretanto, ao analisar este dado, é importante ressaltar que os atendimentos são $100 \%$ SUS e que o hospital é referência na região para gestações de alto risco, o que explica o número elevado de infecções em relação aos dados do país.

Sendo assim, de uma forma geral, podemos perceber uma alta incidência de sífilis congênita, doença facilmente prevenível e tratável se identificada de forma precoce na gestação. 


\section{DETERMINANTES SOCIAIS EM SAÚDE}

De acordo com a Organização Mundial de Saúde (OMS), os determinantes sociais da saúde (DSS) são constituídos por questões socioeconômicas, culturais e ambientais que influenciam as condições de vida e trabalho das pessoas. Portanto, as condições em que as pessoas vivem são determinadas por diferentes fatores de ordem social, político e econômico, impactando diretamente na saúde da população (CDSS, 2010).

Dessa maneira, Magalhães et al (2013) afirmam que a ocorrência de sífilis está relacionada com diversos fatores, entre eles: o baixo nível socioeconômico, a coinfecção por HIV e outras doenças, gravidez na adolescência, comportamento sexual de risco e baixo acesso aos cuidados de saúde.

Em seu estudo descritivo realizado em maternidades públicas de hospitais regionais do Distrito Federal (DF), em que a amostra final foi de 67 gestantes/ puérperas com exame para sífilis reagente, podemos destacar alguns dos resultados obtidos referentes a determinantes sociais. A média de idade das participantes foi de 28,1 anos, com maior proporção entre 19-35. Destas, 64,2\% possuíam Ensino Fundamental completo e 80,6\% possuíam renda familiar de até quatro salários mínimos. Do número total, 06 não realizaram nenhuma consulta de pré-natal $(9 \%)$ e apenas $33(49,3 \%)$ realizaram mais de seis consultas - sendo que o orientado pelo Ministério da Saúde é um mínimo de 6 consultas. Já em relação ao tratamento, 28 gestantes/puérperas foram adequadamente tratadas $(41,8 \%)$ e o principal motivo para a inadequação do tratamento foi a falta $(83,6 \%)$ e/ou inadequação do tratamento do parceiro $(88,1 \%)$.

Apenas 40 foram informadas do diagnóstico de sífilis no pré-natal. Nesta perspectiva, Soares et al (2019, p. 148) citam que mulheres com níveis socioeconômicos mais baixos não costumam realizar o mínimo de consultas recomendadas, "devido, geralmente, a intercorrências que surgem por pertenceram a uma classe social marginalizada, o que não proporciona a criação de vínculo 
entre a mulher e o serviço de saúde, nem garante o acolhimento adequado para o tratamento".

Dessa forma, podemos concluir que a sífilis gestacional costuma ocorrer mais em mulheres jovens, com baixa escolaridade, baixa renda e com baixa instrução, o que traz como consequência uma baixa adesão da gestante aos programas de saúde e uma assistência pré natal inadequada - fato que contribui para persistência da transmissão vertical da sífilis e, portanto, aumento das taxas de incidência.

Lima et al (2015) também consideram que os fatores determinantes estão relacionados não apenas à qualidade da assistência pré-natal ofertada à gestante, mas também a fatores sociais, econômicos, culturais e comportamentais em que elas estão inseridas. Assim, os autores defendem que deve haver uma preocupação voltada para as políticas públicas que sejam focadas nos determinantes sociais a fim de melhorar as condições de saúde desse grupo.

Portanto, a análise dos determinantes sociais de saúde relacionados às altas taxas de incidência de sífilis no país nos permite refletir sobre a importância de intervenções a nível de políticas públicas, que precisam ter como objetivo reduzir desigualdades, facilitar o acesso aos centros de saúde e a informação de qualidade, além de aumentar a adesão desses grupos.

\section{IMPORTÂNCIA DA EDUCAÇÃO NA PREVENÇÃO DE DOENÇAS NA GESTAÇÃO}

De acordo com o Ministério da Saúde, para que o pré-natal seja de fato eficaz, é necessário:

Acompanhamento periódico e contínuo de todas as mulheres na gestação e no puerpério, tanto na unidade de saúde como em seu domicílio, visando garantir o seguimento durante toda a gestação, com classificação do risco gestacional na primeira consulta e nas consultas subsequentes, assegurando esclarecimentos e orientações necessários por meio da realização de ações educativas. (2006, p. 143) 
Para Araújo et al (2011), a educação em saúde é um campo de prática e conhecimento que tem se relacionado cada vez mais com a criação de vínculos entre a ação médica e o cotidiano da população. Sendo assim, é um processo de troca de experiências entre a população como um todo. "Esta prática visa à prevenção de doenças, promove a autonomia dos sujeitos envolvidos, tornando-os sujeitos ativos e transformadores de sua própria vida ou até mesmo da sociedade" (p. 9). Para os autores, as gestantes devem ser alvo da educação em saúde, pois a gestação caracteriza-se por um período mais sensível em que as pacientes estão aptas a receber conteúdos informativos e modificar comportamentos.

Em 2010, Lima et al (2013) realizaram um estudo descritivo junto a um grupo de gestantes de um Centro de Saúde da Família (CSF), com o objetivo de relatar a experiência de acadêmicas de enfermagem na realização de atividades de educação em saúde para a prevenção da transmissão vertical da sífilis. Em uma das etapas, foi realizada uma oficina para abordar temas como sífilis na gestação, consequências da infecção de mãe para filho, modo de transmissão, prevenção e tratamento. $\mathrm{O}$ estudo revelou dificuldades por parte das gestantes em aprender e lembrar as informações que receberam durante as consultas de pré-natal - as gestantes afirmaram já terem tido contato com informações sobre a doença, mas não sabiam ou não lembravam de aspectos como importância da prevenção ou tratamento. Além disso, é relevante destacar que muitas das participantes relataram não terem conhecimento que a infecção poderia ser transmitida ao feto. Desta forma, podemos inferir que as informações recebidas durante as consultas do pré-natal, de forma isolada, muitas vezes não são suficientes para propiciar uma transformação das práticas de prevenção e cuidado em saúde.

Além disso, como apontam Araújo et al. (2011), na maior parte dos serviços de saúde há poucas ações coletivas de educação em saúde, priorizando-se atendimentos individuais. Para os autores, a educação em saúde deveria se voltar, prioritariamente, para intervenções preventivas e em espaços coletivos, como, por exemplo, a oferta de grupos educativos. 
Também pode-se considerar que, no caso de gestantes adolescentes, há ainda uma maior vulnerabilidade, visto que, segundo Benincasa, Rezende e Coniaric (2008), a gestação e as infecções sexualmente transmissíveis (IST) são as principais consequências das relações sexuais desprotegidas, o que torna a prevenção e o acesso das adolescentes a programas eficazes de educação sexual extremamente importantes.

Ainda de acordo com Silva et al. (p. 95), vivemos em um país abrangente e heterogêneo em diferentes áreas, sendo que cada região possui necessidades específicas, bem como doenças mais prevalentes - o que obriga um atendimento e estratégias diferenciadas. Dessa maneira, tal situação gera desafios à saúde pública em relação ao planejamento de estratégias de triagem e prevenção dessas doenças de modo prático e abrangente, o que facilitaria o manejo das gestantes com um diagnóstico precoce adequado (DE PASCHALE et al, 2014).

\section{COMENTÁRIOS FINAIS}

Apesar da sífilis ser uma doença de conhecimento bem estabelecido, com tratamento conhecido e eficaz, ainda se pode observar um grande número de gestantes infectadas, como demonstrado pela observação dos autores deste texto. Tal fato faz refletir que ainda há muitas gestantes que não seguem as recomendações de prevenção e tratamento para a doença, o que mostra uma necessidade de uma maior abrangência em estratégias de educação em saúde.

Além disso, é importante destacar que, na medida em que determinados grupos apresentam maior vulnerabilidade (baixa renda, baixa escolaridade, muIheres jovens, entre outros), há uma maior necessidade de intervenções educativas que busquem a redução das taxas de sífilis congênita. Assinala-se ainda que tais ações se mostram mais eficazes quando realizadas no âmbito coletivo e não apenas no espaço de consultas de pré-natal, mas também sob forma de grupos de gestantes, campanhas na comunidade, divulgação na mídia sobre a doença e medidas de prevenção, entre outras. 


\section{REFERENCIAS}

ARAÚJO, Maria et al. Educação em saúde - estratégia de cuidado integral e multiprofissional para gestantes. Revista da ABENO. v.11, n. 2, p. 8-13, 2011. Disponível em http://revodonto.bvsalud.org/pdf/abeno/v11n2/a02v11n2.pdf . Acesso em 30/09/21.

BENINCASA, Miria; REZENDE, Manuel Morgado; CONIARIC, Janaína. Sexo desprotegido e adolescência: fatores de risco e de proteção. Psicologia teoria e prática. São Paulo, v. 10, n. 2, p. 121-134, dez. 2008. Disponível em <http://pepsic.bvsalud.org/scielo.php?script=sci_arttext\&pid=S1516-36872008000200010\&lng=pt\&nrm=iso >. Acesso em: 01/10/21.

CDSS. Redução das desigualdades no período de uma geração. Igualdade na saúde através da acção sobre os seus determinantes sociais. Relatório Final da Comissão para os Determinantes Sociais da Saúde. Portugal, Organização Mundial da Saúde, 2010. Acesso em: 02/10/21.

DE PASCHALE, Massimo et al. Triagem pré-natal para infecções por Toxoplasma gondii, Cytomegalovirus, rubéola e Treponema pallidum no norte do Benin. Tropical Medicine \& International Health. Oxford, v. 19, n. 6, p. 743-746, jun. 2014. Disponível em: https://onlinelibrary.wiley.com/doi/epdf/10.1111/tmi.12296 Acesso em: 01/10/21.

FAREZIN, Rafael, BERTOLINI, Dennis, DEMARCHI, Izabel. Prevalência de sorologia positiva para HIV, hepatite $B$, toxoplasmose e rubéola em gestantes do noroeste paranaense. Maringá, Revista Brasileira de Ginecologia e Obstetrícia. v. 35, n. 2, p. 66-70, 2013. Disponível em https://www.scielo.br/j/rbgo/a/z5qbKQW8khq3sxnkh9DW7bM/?lang=pt\&format=pdf Acesso em 01/10/21.

Instituto de Pesquisa e Ensino em Saúde Infantil (PENSI). Quadruplica o nascimento de crianças com sífilis no Brasil. 12/03/20. Disponível em: https://institutopensi.org.br/blog-saude-infantil/quadruplica-o-nascimento-de-criancas-com-sifilis-no-brasil/ . Acesso em 02/10/21.

LIMA, Valdênia et al. A sífilis congênita e seus determinantes sociais da saúde. SANARE, v.14 - Suplemento 1 - COPISP - 2015. Disponível em: https://sanare.emnuvens.com.br/sanare/article/download/706/408\#: :text=CONCLuS\%C3\%830\%3A\%20Pode \%2Dse $\% 20$ inferir\%20que,em $\% 20$ que $\% 20$ as $\% 20$ mesmas\%20vivenciam. . Acesso em: 02/10/21. 
LIMA, Gleiciane et al. Educação em saúde sobre sífilis com um grupo de gestantes: um relato de experiência de acadêmicas de enfermagem. SANARE, Sobral, v. 12, n. 2, p.59-62, jun./dez. 2013. Disponível em: https://sanare.emnuvens.com. br/sanare/article/download/384/276. Acesso em: 10/10/21.

MAGALHÃES, Daniela et al. Sífilis materna e congênita: ainda um desafio. Cadernos Saúde Pública. Rio de Janeiro, v. 29, n. 6, p. 1109-1120, jun, 2013. Disponível em: https://www.scielo.br/j/csp/a/WM4wjfcJBy9Yb4FTvjhvCDz/?lang=pt\&format=pdf . Acesso em: 01/10/21.

MINISTÉRIO DA SAÚDE. Boletim Epidemiológico de Sífilis. Brasília, Publicado 29.10.2020. Disponível em: http://www.aids.gov.br/pt-br/pub/2020/boletim-sifilis-2020 . Acesso em 01/10/21.

MINISTÉRIO DA SAÚDE. Pré-natal e Puerpério; Atenção qualificada e humanizada. Brasília - DF, 2006. Disponível em: https://bvsms.saude.gov.br/bvs/publicacoes/manual_pre_natal_puerperio_3ed.pdf. Acesso em 10/10/21.

SILVA, Marcos et al. O perfil epidemiológico de gestantes atendidas nas unidades básicas de saúde de Gurupi, Tocantins. Universitas: Ciências da Saúde. Brasília, v. 13, n. 2, p.93-102, jul./dez. 2015. Disponível em: https://www.arqcom.uniceub. br/cienciasaude/article/viewFile/3305/2864. Acesso em 01/10/21. 


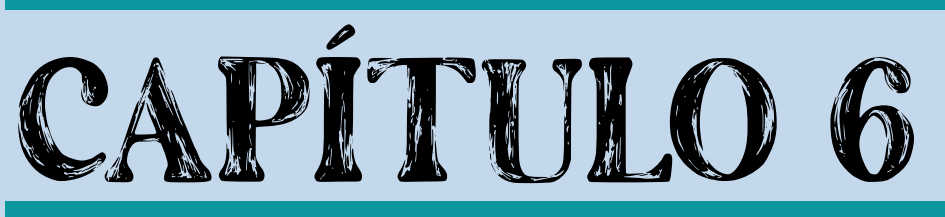

\section{SAÚdE DA POPULAÇÃO EM SITUAÇÃO DE RUA E $O$ CONTEXTO PANDÊMICO}

lagro Cesar De Almeida

Thais Fernanda Baier

Fabiana Rafaela Santos De Mello 


\section{INTRODUÇÃO}

A situação da população que habita nas ruas apresenta-se com definições distintas em sua totalidade, contudo, com uma mesma problemática: o aumento do seu contingente populacional em situações de crise, como a pandemia por Covid-19. No Brasil, de acordo com o decreto número 7.053/2009 da Política Nacional para a População em Situação de Rua (PNPR), essa população pode ser caracterizada como "grupo populacional heterogêneo que possui em comum a pobreza extrema, os vínculos familiares interrompidos ou fragilizados e a inexistência de moradia convencional regular, que utiliza os logradouros públicos e as áreas degradadas como espaço de moradia e de sustento, de forma temporária ou permanente, bem como as unidades de acolhimento para pernoite temporário ou como moradia provisória" (IPEA, 2020).

Quanto ao auxílio a esse grupo, apesar dos planos e ações emergenciais, sobretudo na pandemia, tem-se uma maior dificuldade nesse cenário quanto ao acesso à higiene, água e alimentação, tal como ao abrigo. No Brasil, essas particularidades são bem definidas, onde há uma tendência à naturalização do fenômeno que, no país, se faz acompanhada da quase inexistência de dados e informações científicas sobre o assunto e do escasso número de políticas públicas para enfrentá-lo (SILVA, 2020).

Sob contextos de crise, como durante a pandemia gerada pela Covid-19, reações emocionais relacionadas a perdas e incertezas expõem a população a situações atípicas e emergenciais. Nesse sentido, os danos causados a comunidades específicas, principalmente aquelas com em situação de vulnerabilidade, vão muito além das consequências clínicas sofridas pela infecção do SARS-CoV-2, o vírus causador da Covid-19, afetando tanto as bases sociais quanto econômicas até então estruturadas.

Desde o primeiro momento de disseminação do vírus, reações mundiais se propagaram, essencialmente em torno de desconfianças e da busca de respostas. No Brasil, o dia 26 de fevereiro marcou o primeiro pico de preocupações que 
cercaram a confirmação do primeiro caso de Covid-19 no país. Assim, durante os alertas no mês seguinte, a mobilização de políticas públicas deu transparência a vulnerabilidades antes negligências pelo aparelho público - ainda que presentes em diversos debates sociais - onde então diferentes populações, como de pessoas em situação de rua, se viram com mais uma condição somada às suas precariedades: o enfrentamento ao vírus (SILVA, 2020).

Diante desse cenário, o seguinte trabalho estrutura-se por meio da análise de projetos que visam a minimização dos impactos negativos da pandemia sobre a vida das pessoas que vivem em condições de rua. Tal abordagem foi utilizada como uma forma de evidenciar a importância de projetos sociais para a educação em saúde, direcionadas para pessoas que vivem em situação de rua, especialmente durante a pandemia da Covid-19, a partir de suas vulnerabilidades.

\section{METODOLOGIA}

O presente estudo trata-se de uma discussão com o objetivo de problematizar situações de vulnerabilidade em saúde e práticas de educação em saúde para pessoas em situação de rua durante a pandemia. Além disso, é debatida a correlação de tais questões com o espaço urbano. Para tanto, fez-se uso de projetos realizados nessas circunstâncias - Quarentena Sem Fome, Pretas Ruas e Aquabox: um banho de solidariedade. A literatura utilizada foi obtida através de descritores ("Pessoas em Situação de Rua", "Covid-19", assim como suas traduções para o inglês) no Portal de Periódicos CAPES, além das plataformas SCOPUS e Google Acadêmico.

\section{POPULAÇÃO EM SITUAÇÃO DE RUA E SAÚDE}

A população que vive em situação de rua, coletivamente, enfrenta grandes desafios sociais e a marginalização dentro dos sistemas de saúde. A partir disso, com o início da pandemia da Covid-19 no Brasil, em março de 2020, as perspectivas da população que vive em situação de rua se agravaram drasticamente. Atualmente, estima-se que mais de 220 mil pessoas vivem em situação de rua 
no Brasil, com concentração principalmente nas regiões sudeste, nordeste e sul. Esse número, infelizmente, tende a aumentar com a crise social, política e econômica que vivencia o Brasil, atualmente acentuada pela crise na saúde (IPEA, 2020).

O risco de contrair o vírus da SARS-CoV-2 e desenvolver complicações pela forma da doença grave, aumenta consideravelmente pelas vulnerabilidades vividas pela população em situação de rua somada a frequentes impossibilidades de acessar cuidados de saúde, seja em postos de saúde, ambulatórios de campanha ou hospitais, pela imobilidade a longas distâncias ou pelo receio do estigma social e consequente discriminação, o que impede a correta triagem, isolamento, quarentena e cuidados hospitalares para essa população (IPEA, 2020).

Da mesma forma, a falta de acesso regular a suprimentos de higiene básica, como água limpa, sabão e álcool em gel, bem como o acesso a máscaras de proteção respiratória, facilitam a transmissão do vírus. Por esses motivos, torna-se fundamental que a população que vive em situação de rua no contexto da pandemia do coronavírus receba urgente suporte e medidas que visem a educação em saúde. O acesso a higiene básica, alimentação adequada, alojamentos seguros, assistência médica de qualidade com serviço psiquiátrico disponível e auxílio financeiro são imprescindíveis para atenuar as vulnerabilidades e disparidades que essa população enfrenta a cada dia (IPEA, 2020).

Assim, somado a necessidade do suporte e medidas em saúde, bem como de sistemas organizados e estruturados para apoiar os mais vulneráveis, como os em situação de rua, infelizmente, teve-se a restrição quanto a esses acessos na pandemia, evidenciando o agravamento da vulnerabilidade desse grupo. Para tentar minimizar esses danos é importante o fortalecimento de ações como a PNPR, para assegurar maior acesso amplo, integral e seguro aos serviços e programas que integram as políticas públicas de saúde, fazendo com que a população de rua continue podendo contar com essas estruturas de sistema de saúde nesse mesmo durante um período tão atípico (IPEA, 2020). 
A saber, segundo pesquisa censitária da população de rua na cidade de São Paulo (cidade com maior número de moradores de rua do país), em 2019, mostrou que a maioria $(40,3 \%)$ habita as ruas devido à conflitos familiares, sendo outros motivos de maior prevalência a perda de trabalho $(23,1 \%)$, uso de drogas ilícitas (19,0\%), alcoolismo (14,3\%) e perda de moradia (12,9\%). Assim também, na mesma pesquisa, 29,\% declararam ser atendidos em equipamentos de saúde, 22,9\% em Centros de Referência Especializados da Assistência Social e 19,3\% pelo Consultório na Rua (projeto que presta atendimentos às pessoas em maior vulnerabilidade social) (SMADS, 2020).

Nesse contexto, as biopolíticas ganham importância no manejo da saúde coletiva. A biopolítica agrupa em complexos de forças as instituições que se voltam para a gestão das condutas individuais e coletivas, ainda que entendidas como não políticas, gestão essa tão fundamental na saúde da população em situação de rua, que necessita de estratégias de segurança e governabilidade (DARSIE; HILLESHEIM; WEBER, 2021). No contexto da pandemia, paradoxalmente, ao mesmo tempo que surge uma série de manifestações de solidariedade em âmbito mundial, também se expõe e se aprofunda as desigualdades existentes no mundo, entre países e no interior de cada um deles (BUSS, 2020).

Ainda, no que se refere a busca de medicações e acesso à vacina, a medida que se visa sanar essa lacuna, cria-se outra: produção e ampliação de novos vulneráveis. Isso porque, conforme as intervenções para diminuir a propagação do vírus, aprofundou-se a relação de desigualdade econômica e social já existente. Dessa forma, o distanciamento social, tendo na saúde seu componente essencial, foi apenas a legitimação de um quadro já vivenciado e naturalizado sobre diversas populações, como a moradora de rua, refletindo diretamente na acentuação do seu esquecimento (LEITE, 2020).

Nas áreas onde a pobreza urbana é mais acentuada, o novo coronavírus avança de forma mais rápida. Importante salientar ainda que, além do desigual acesso à saúde, há também a incidência de distúrbios mentais relacionados (e agravados) durante esse período. Além disso, apesar de dados escassos no que 
se refere a esse assunto, é significativo o aumento de relatos associados à saúde mental, como ansiedade, depressão, distúrbios do sono e esgotamento emocional. Apesar do elevado número de ensaios clínicos quanto a medicamentos e vacinas, as recomendações variam entre países e sociedades médicas, inferindo, assim, notável incerteza quanto às informações relacionadas à Covid-19. Assim, busca por medicações, o acesso à vacina e o aumento de distúrbios mentais, associado à crise pandêmica, pode ser percebida como três pilares no imenso colapso do molde econômico atual (BUSS, 2020).

Quando questiona-se o acesso às cidades como um ambiente colaborativo de convívio e, assim, o direito à moradia, o agravamento dos problemas urbanos fez com que a ONU, desde 1991, durante o Comitê sobre os Direitos Econômicos, Sociais e Culturais, definisse que a moradia adequada deve atender à algumas medidas, havendo necessidade delas serem adotadas pelo Estado como maneira de garantir qualidade de vida, bem estar e saúde à sua população. Os critérios respondem a segurança de posse (como forma de garantir a proteção legal contra despejos forçados, perseguição e outras ameaças aos ocupantes), disponibilidade de serviços e infraestrutura (para garantir água potável e saneamento básico, assim como energia, aquecimento, iluminação, armazenagem de alimentos e coleta de lixo), economicidade (onde o custo de moradia não deve comprometer outros direitos humanos de seus ocupantes), habitabilidade (garantia de segurança física e estrutural), acessibilidade (abrangendo as necessidades específicas de quem habita), localização (para garantir a aproximação às oportunidades de emprego, serviços de saúde, escolas e outras instalações sociais, assim como garantir a distância de áreas de poluição e perigo) e adequação cultural (mantendo respeito à expressão de identidade cultural dos indivíduos) (ONU, 1991).

Dentro desse panorama, a população em situação de rua se caracteriza como um grupo populacional heterogêneo, com vínculos sociais fragilizados e em situação de extrema pobreza, na maioria das vezes permanente (DE PAULA et al., 2020). Portanto, através desse contexto de vulnerabilidades, é possível 
analisar os impactos a essa população quando acometida por cenários de crise, como a pandemia gerada pelo SARS-COV-2, onde seus prejuízos acabam intimamente ligados à determinantes sociais, não somente à patogenicidade do vírus (ESTRELA et al., 2020). Por isso, a crise sanitária atual legitima ainda mais as necessidades de uma população desassistida, demonstrando que as atuais políticas de saúde e bem viver não as integra em seu escopo, nem mesmo durante uma realidade pautada por emergências e atenção aos vulneráveis (LEITE, 2020).

\section{SAÚDE: EDUCAÇÃO, INFORMAÇÃO E AÇÃO}

De acordo com o exposto, as barreiras e exclusões impostas pela pandemia demonstram a necessidade de conexões entre espaço urbano, comunidades e a ocupação das cidades. Porém, nessa relação de fatores, o modelo de ocupação brasileiro gera um crescimento polarizado das cidades, refletindo na segregação que se manifesta através da pobreza. Dessa forma, o combate ao agravamento dos indicadores de desenvolvimento social, diante das distintas realidades, demanda o trabalho conjunto entre Estado e sociedade, cabendo a valorização de estudos locais para avaliação epidemiológica e o apoio à atores sociais que tentam suprir as carências do Estado (NUNES; BONATTO; RODRIGUEZ, 2020).

Nesse contexto, projetos de educação em saúde e de proteção social surgem ainda que em meio ao distanciamento social. Nos últimos anos, políticas específicas implementadas por secretarias de saúde de estados e municípios vivenciam rotineiramente o isolamento sofrido por pessoas com moradia nas ruas, como é o caso de projetos como o Consultório na Rua, que aproxima essas pessoas aos serviços oferecidos pelo SUS. Contudo, para que não se agrave as dificuldades estruturais da vida coletiva nas grandes cidades, diversos segmentos acabam recorrendo ao apoio da economia solidária e de novas formas de organização social comunitárias e periféricas (MENDONÇA et al., 2020). 
Logo, diante das lacunas nas ações estatais de assistência à população na pandemia, surgem movimentos sociais de cooperação e solidariedade pautados por iniciativas coletivas e, algumas, contando com apoio de instituições e governos locais. Assim, ao passo que matérias na mídia e em redes sociais denunciam descasos e segregação, iniciativas a favor da preservação da vida acabam agindo por meio da doação de alimentos, produtos de higiene e, também, por intermédio da liderança e comunicação social que acabam informando, educando e resguardando a saúde de moradores de rua (MENDONÇA et al., 2020). Um desses projetos denomina-se "Quarentena Sem Fome", adotado em diversas cidades pelo país e que promove o planejamento de distribuição de "marmitas/quentinhas" para grupos moradores de rua, visto que, com a diminuição de circulação nos centros urbanos e a adoção de home office, diminuiu-se substancialmente as doações voluntárias, muitas vezes sendo essas as únicas fontes de obtenção de alimentos dessa população (CONEXÃO SOLIDÁRIA, 2020).

Ainda, outro projeto que realiza ações sociais voltadas à população de rua é o "Pretas Ruas", idealizado por Pamella Lessa e Pâmela Oliveira na cidade do Rio de Janeiro. Especialmente na zona norte, conhecida por carecer de medidas de suporte, o projeto realiza a distribuição de kits de higiene masculinos e femininos e alimentos a cada 15 dias, aos domingos para pessoas que vivem em situação de rua, assim, contribuindo às práticas de higiene recomendadas para prevenir a contaminação pelo vírus SARS-CoV-2. Além disso, realiza campanhas na internet para promover a conscientização sobre as necessidades da população de rua na pandemia de Covid-19, reforçando as formas de combate como hábitos de higiene e isolamento social (COLETIVO PRETAS RUAS, 2021).

Por fim, ressalta-se o projeto denominado "Aquabox: um banho de solidariedade", um projeto idealizado pelo arquiteto Maurício Santiago e o psicólogo Vilmar Sousa na cidade Belo Horizonte com o apoio do Instituto de estudos do Desenvolvimento Sustentável e em parceria com o Conselho de Arquitetura e Urbanismo do Estado de Minas Gerais, o projeto visa instalar uma estrutura de 
contêiner destinada a higiene pessoal com instalação de chuveiros e lavadora de roupas para a população do Complexo da Lagoinha, local onde a uma grande concentração de pessoas vivendo em situação de rua. A ação social ainda aguarda a autorização do território pela Prefeitura de Belo Horizonte para instalação do projeto, que certamente irá auxiliar e atenuar as dificuldades encontradas pela população que vive em situação de rua, especialmente na pandemia gerada pela Covid-19 (IEDS, 2021).

Através do exposto, o foco das estratégias, quando analisadas em perspectivas biopolíticas, encontra-se no gerenciamento da vida das populações e na produção de conhecimentos a fim de melhor administrá-los e transformá-los. Por esse motivo que a educação sobre os cuidados em saúde, adquire vital importância, por ter como finalidade a orientação sobre riscos para promover segurança individual e, indissociavelmente, coletiva (DARSIE; HILLESHEIM; WEBER, 2021).

\section{CONSIDERAÇÕES FINAIS}

Em razão do cenário pandêmico, principalmente por suas incertezas, a comunicação em saúde é indispensável estrategicamente, de forma a não ficar restrita, sem transferência de informações e diálogos (MENDONÇA et al., 2020). Desse modo, durante esse contexto, atuar de maneira colaborativa constitui uma ferramenta importante para compartilhar esforços e promover a elaboração de redes cooperativas para o desenvolvimento da saúde (BUSS, 2020). Essas redes podem ser desenvolvidas por profissionais, corpo social ou instituições, com intuito de obter melhor resposta a determinado problema de saúde pública ou ao sistema de saúde, provendo uma ação coletiva.

O movimento social nas comunidades, paralelo ao Estado, presta, na atualidade, um cuidado paliativo quanto a esses grupos sociais, especialmente em situação de rua, que objetiva melhoria da qualidade de vida e cria expectativa de fortalecimento diante da sociedade e pressão por novas estruturas urbanas 
mais democráticas, baseadas na realidade das carências sociais, exponenciadas agora pela pandemia (MENDONÇA et al., 2020). Com isso, esses projetos visam minimizar essa lacuna quanto ao amparo, não apenas na resolução de carências, mas também, quanto ao acesso e a propagação de informações de saúde e educação, essenciais para promover melhor cuidado e prevenir doenças. Essas ações se encaixam no escopo daquilo que se entende por estratégias biopolíticas.

\section{REFERENCIAS}

BOURDIEU, Pierre. Sobre o poder simbólico. Trad. Fernando Tomaz. Rio de Janeiro: Bertrand Brasil, 2001.

BUSS, P.M.;FONSECA, L.E., Diplomacia da saúde e Covid-19: reflexões a meio caminho [online], p. 360. Rio de Janeiro: Observatório Covid-19 Fiocruz; Editora FIOCRUZ: 2020. ISBN: 978-65-5708-029-0.

COLETIVO PRETAS RUAS. Projeto veiculado em <https://pretasruas.com.br/>. Rio de Janeiro: 2021.

CONEXÃO SOLIDÁRIA. Campanha EPTV, veiculada em 16/02/2020. Disponível em <https://conexaosolidaria.eptv.com.br/campanhas/central/NOT,0,0,1531958,quarentena-sem-fome.aspx>.

DARSIE, Camilo; HILLESHEIM, Betina; WEBER, Douglas Luís. O discurso de controle de doenças da Organização Mundial da Saúde e a produção de espacialidades nacionais. Interface - Comunicação, Saúde, Educação, v. 25. FapUNIFESP: 2021. http://dx.doi.org/10.1590/interface.200587.

DEMARZO, M. M. P.; AQUILANTE, A. G. Saúde escolar e escolas promotoras de saúde. In: Programa de Atualização em Medicina de Família e Comunidade. Porto Alegre: Artmed, 2008.

ESTRELA, Fernanda Matheus et al. Pandemia da Covid 19: refletindo as vulnerabilidades à luz do gênero, raça e classe. Ciência \& Saúde Coletiva, v. 25, n. 9, p. 3431-3436. FapUNIFESP. São Paulo: 2020. http://dx.doi.org/10.1590/141381232020259.14052020. 
INSTITUTO DE ESTUDOS DO DESENVOLVIMENTO SUSTENTÁVEL (IEDS). Aquabox: um banho de solidariedade. Projeto veiculado em <https://www.institutoieds.com/aquabox>. Belo Horizonte: 2021.

INSTITUTO DE PESQUISA ECONÔMICA APLICADA (IPEA). POPULAÇÃO EM SITUAÇÃO DE RUA EM TEMPOS DE PANDEMIA: UM LEVANTAMENTO DE MEDIDAS MUNICIPAIS EMERGENCIAIS. Nota técnica Nº 74. Brasília: 2020.

LEITE, Marcia Pereira. Biopolítica da precariedade em tempos de pandemia. Dilemas: Estudos de Conflito e Controle Social, Rio de Janeiro, p. 1-16, 2020.

MENDONÇA, Maria Helena Magalhães de et al. A pandemia Covid-19 no Brasil: ecos e reflexos nas comunidades periféricas. APS em Revista, Rio de Janeiro, v. 2, n. 2, p. 162-168, 8 jun. 2020. Lepidus Tecnologia. http://dx.doi.org/10.14295/ aps.v2i2.124.

NUNES, Nilza Rogéria de Andrade; BONATTO, Daniella do Amaral Mello; RODRIGUEZ, Andra. Os (in)visíveis da cidade: pobreza, segregação urbana e população em situação de rua em tempos de pandemia. Cidades: dilemas, desafios e perspectivas. p. 175-196. Universidade Veiga de Almeida. Rio de Janeiro: 2020.

SECRETARIA DE ASSISTÊNCIA DO DESENVOLVIMENTO SUSTENTÁVEL (SMADS). Pesquisa censitária da população em situação de rua: Caracterização socioeconômica da população em situação de rua e relatório temático de identificação das necessidades desta população na cidade de São Paulo. Relatório Final da Pesquisa Amostral do Perfil Socioeconômico da Prefeitura de São Paulo. São Paulo: 2020.

SILVA, Ana Paula Cardoso da. Em tempos de Covid-19: fique em casa! mas, onde ficam os que "moram" nas ruas?. Revista Vértices, v. 22, n. , p. 952-964, 31 dez. 2020. Essentia Editora. http://dx.doi.org/10.19180/1809-2667.v22nespecial2020p952-964.

LIU, Michael; HWANG, Stephen W.. Health care for homeless people. Nature Reviews Disease Primers, v. 7, n. 1. 14 jan. 2021. Springer Science and Business Media LLC. http://dx.doi.org/10.1038/s41572-020-00241-2. 
HOWELLS, Kelly; BURROWS, Martin; AMP, Mat; BRENNAN, Rachel; YEUNG, Wan-Ley; JACKSON, Shaun; DICKINSON, Joanne; DRAPER, Julie; CAMPBELL, Stephen; ASHCROFT, Darren. Exploring the experiences of changes to support access to primary health care services and the impact on the quality and safety of care for homeless people during the Covid-19 pandemic: a study protocol for a qualitative mixed methods approach. International Journal For Equity In Health, v. 20 , n. 10 jan. 2021. Springer Science and Business Media LLC. http://dx.doi. org/10.1186/s12939-020-01364-4. 




\title{
PRÁTICAS DE EDUCAÇÃO
}

\section{PARA SAÚDE NO MEIO RURAL:}

\section{UMA ANÁLISE DO PROJETO}

\section{"VIDA E SAÚDE NO CAMPO:}

TECNOLOGIAS EDUCATIVAS

\section{DESPERTANDO CONSCIÊNCIA"}

\author{
Lucas Fernandes Mein \\ Jonathas Gauciniski \\ Tomaz Mazuco Rodriguez \\ Leonardo Teixeira Gomes
}




\section{INTRODUÇÃO}

O Brasil tem como característica importante ser um dos pólos de produção agrícola no mundo. Isso se deve em boa parte aos grandes produtores que utilizam de alta tecnologia e implementos para proporcionar alta produtividade. Paralelamente, a agricultura "tradicional", sintetizada pela pequena agricultura familiar, em diversos casos, não dispõem de altos recursos, insumos e sobretudo instrução sobre o manuseio de defensivos agrícolas e outros materiais potencialmente nocivos. Ademais, estão expostos a acidentes de trabalho, acidentes com animais venenosos ou peçonhentos. Não obstante, "todos esses fatores vêm acarretando acidentes, doenças e até mortes e, consequentemente, gerando atendimentos nos serviços integrantes do Sistema Único de Saúde (SUS)" (FIOCRUZ, 2005, p. 2)

Observando a prática rural, constata-se que a cartilha da FIOCRUZ (2005) sobre o projeto em questão expõem que a prática frequente, em grande parte da agricultura brasileira, do uso de múltiplos produtos tóxicos, por longos períodos, em jornadas prolongadas e sem Equipamentos de Proteção Individual (EPI) tem tido como consequência diversos problemas de saúde para a população, incluindo intoxicações agudas e crônicas de todos aqueles que interagem direta e indiretamente com esses produtos. É reiterado o fato da potencialidade desse problema quando destacado que os efeitos dos defensivos podem ser sentidos, outrossim, nas famílias dos agricultores, e no meio ambiente que circunda a propriedade. Torna-se, não obstante, um potencial e real problema de saúde pública.

A pesquisa "Vida e Saúde no campo: tecnologias educativas despertando consciências" é um projeto-piloto subsidiado financeiramente pelo Programa de Desenvolvimento Tecnológico e Saúde Pública (PDTSO), coordenado pela Vice-Presidência de Pesquisa e Desenvolvimento Tecnológico (VPPDT) da Fiocruz. A pesquisa foi desenvolvida em parceria com a coordenação das equipes de 
saúde da família da Secretaria Municipal de Saúde de Petrópolis (RJ). Foram envolvidos 35 profissionais, entre médicos, enfermeiros, dentistas, auxiliares de enfermagem, agentes comunitários de saúde e auxiliar de consultório dentário integrantes de três equipes com atuação em áreas rurais que se destacavam pela produção agrícola familiar com uso de agrotóxicos.

Assim, inicialmente foi determinado "o nível de conhecimento desses profissionais sobre o impacto do trabalho agrícola na saúde; o processo e a organização do trabalho; e as atividades desenvolvidas pelas equipes, dentre outros aspectos; que contribuíram para a estruturação de um curso de aperfeiçoamento profissional (FIOCRUZ, 2005, p. 2)". Isso mostrou-se de extrema importância uma vez que

Para que o profissional de saúde possa atingir com excelência seu desempenho nas práticas educativas, requer que o mesmo possua proximidade com a realidade com a qual será objeto de trabalho, além de possuir visão crítica da sua atuação, bem como reflexão do seu papel como educador (FERNANDES et al., 2010, p. 567).

Através de um curso de aperfeiçoamento profissional para esses trabalhadores da saúde participantes do projeto tiveram suas visões ampliadas sobre diversos temas que permeiam a prática rural. Agrotóxicos, saúde e meio ambiente, valorização da atividade agrícola e os conhecimentos teóricos e práticos. Sendo assim, após essa formação, diversos materiais de educação para saúde foram produzidos. O projeto procurou desenvolver materiais audiovisuais e impressos que tornassem o processo de educação para saúde mais acessível, adequado e didático para a população em questão.

Cabe a seguir, realizar a uma análise, a partir de referenciais teóricos, sobre as características, importâncias e bases dos usos dos materiais audiovisuais e impressos para a educação em saúde. Para tanto, na sequência é apresentado o referencial teórico sobre educação para saúde e em seguida a análise sobre os materiais produzidos pelo projeto. 


\section{EDUCAÇÃO EM SAÚDE}

A educação no âmbito da saúde constitui-se em um processo complexo, o qual abrange diversas dimensões acerca do indivíduo e transcende o conceito minimalista de uma simples transmissão de informações relacionadas à área da saúde (SALCl et al., 2013). Dessa forma, a comunicação e a informação emergem como ferramentas fundamentais nesse processo, considerando o contexto pertencente ao indivíduo para tornar efetiva a conversão do diálogo em conhecimento.

Entende-se, assim, a Educação em Saúde como um instrumento que visa criar meios para que ocorram mudanças pretendidas no comportamento em relação à saúde (GAZZINELLI et al., 2005). A Educação para Saúde assume um caráter mais verticalizado, a partir de práticas educativas baseadas em uma hierarquia da informação a fim de orientar uma conduta ao público ao qual se destina - assume-se, então, um aspecto normativo, configurando uma relação direta entre o conhecimento instituído e o comportamento adotado.

Portanto, tem-se que

A Educação para a Saúde é definida como a mudança do enfoque predominantemente biológico e curativo, para o olhar preventivo e de promoção da saúde, englobando os diversos contextos (sociais, culturais, ambientais, etc.) em que o ser humano está inserido, fazendo-se valer a escuta e a acolhida à realidade dos educandos, predominando a dimensão subjetiva, cidadã e humanizada da prática em saúde. (COSCRATO; BUENO, 2012, p. 715)

Nesse contexto, são diversas as ferramentas que podem ser utilizadas na instrumentalização da educação inerente à saúde, desde produtos audiovisuais - como vídeos, músicas, materiais impressos - até atividades lúdicas que demandam uma participação mais ativa do receptor no processo de construção do conhecimento. Tais recursos permitem catalisar o desenvolvimento do saber, configurando-se como alternativas vantajosas a métodos ortodoxos. O uso de material produzido em vídeo, exemplificativamente, é positivo à medida que "se 
dissemina de forma processual e não hierárquica no tecido social, confundindo os papéis de produtores e consumidores, podendo resultar daí um processo de troca e de diálogo não muito comum em outros meios" (PIRES, 2010).

Assim, independente da estratégia utilizada, a intervenção educacional torna-se plena à medida que os recursos empregados são capazes de construir um novo saber passível de produzir transformação no contexto desejado.

\section{VIDA E SAÚdE NO CAMPO: TECNOLOGIAS EDUCATIVAS DESPERTANDO CONSCIÊNCIA}

O projeto foi desenvolvido com o uso de materiais audiovisuais e impressos com o intuito de propagar informações de modo que qualquer pessoa possa ter fácil acesso, independente da faixa etária. A implementação da propagação de informações relacionadas a educação em saúde já se demonstrou historicamente relevante no Brasil durante a década de quarenta, com o avanço desse pensamento com a implementação do Serviço Especial de Saúde Pública (SESP), ressaltando a possibilidade do uso de produtos audiovisuais e impressos como meio relevante para promoção de educação em saúde.

Dentre os meios que seriam utilizados pelo programa para a propagação de educação em saúde, são relevantes mencionar o uso de programas de rádio, que é o meio de comunicação de mais fácil acesso para a população, e a produção e divulgação de um livro de história, que além de trazer informações relevantes sobre a relação saúde e meio ambiente, que pode ser implementado na vida escolar e aprendizado dos jovens.

Segundo Santos (2006), para determinar se o uso de um meio foi eficiente no intuito de educação em saúde, deve-se realizar uma série de análises relativas às mudanças na vida da população que se deseja atingir, o desempenho dos profissionais acerca do que se determina como ação para promover educação em saúde e conquanto a didática e aproveitamento dos meios empregados para com a população. Levando isso em consideração, os meios propostos pelo projeto têm o potencial de ser eficiente, uma vez que cumpre com os requisi- 
tos propostos anteriormente, melhorando a qualidade de trabalho e de vida da população rural.

Não obstante, materiais de apoio são de extrema valia, pois estimulam a aprendizagem das populações rurais sobre as tecnologias disponíveis no campo e, assim, paulatinamente, tornam-se indivíduos mais engajados. Diferentes materiais audiovisuais e impressos despertam consciência e interesse, com o intuito de refletir, questionar, compartilhar, debater, cooperar e agir para preservar, manter a vida e promover a saúde no campo (FIOCRUZ,2005). Além disso, faz-se necessário a participação de profissionais de saúde da família, porque, além de seus conhecimentos teórico-prático, também auxiliá-lo-iam a desenvolver atividades de atenção básica e de vigilância em saúde, utilizando esses recursos materiais que facilitariam a sensibilização (FIOCRUZ, 2005).

Outrossim, de acordo com Werner (2004), conforme citado por Rezende (2009 p. 9): "temos que considerar a importância que a participação do leitor/espectador ganha à medida que nos aproximamos de práticas de intertextualidade como reforça". Werner (2004, p. 3) afirma que "a intertextualidade opera através dos olhos do observador. Ela refere-se às formas como os textos, sejam verbais ou visuais, são interpretados à luz do outro para produzir novos significados" (apud REZENDE, 2009). Desta maneira, podemos considerar que, quando fazemos referência ao conceito de intertextualidade, estamos realizando uma alusão não só às formas (como os blocos de imagens-sons e textos de um filme relacionam-se entre si) mas, também, como os espectadores os interpretam a partir de um pano de fundo de outros textos, imagens e sons diversos (REZENDE, 2009).

Dessa forma, torna-se factível a aplicabilidade do projeto analisado, tendo em vista que este vai de encontro aos processos educativos tradicionais verticalizados e incorpora os sujeitos na formação do saber. Os recursos aplicados permitem, portanto, estabelecer uma conexão mais ampla com a população alvo, permitindo que esta seja ativa no processo de construção do conhecimento, 
atingindo, assim, a modificação almejada. Isso se deve ao fato de o projeto ser alicerçado em ferramentas educacionais contemporâneas (vídeo, áudio e material gráfico), as quais tem se mostrado eficientes devido à sua característica de universalidade, agregando o caráter lúdico à mecânica tradicional inerente ao ensino e despertando a atenção e a interação do indivíduo.

Infere-se, dessa forma, que os objetivos propostos se tornam plausíveis em um cenário que diverge de um ensino formal. Um dos aspectos visados pelo projeto consiste em facilitar e estimular o compartilhar de saberes, a reflexão, o debate sobre os temas trabalho agrícola, agrotóxicos, saúde e meio ambiente entre as equipes de saúde da família e populações rurais de níveis culturais diferenciados, permitindo a participação de indivíduos que tiveram pouco ou nenhum acesso à educação formal. Torna-se relevante, nesse contexto, a penetração da informação nas diversas camadas sociais, de forma a integrar a população com baixa instrução e analfabeta, parcela ainda relevante no ambiente rural. É imprescindível, portanto, que haja uma sinergia entre a população, o agente de saúde, e o instrumento educador para que o processo transformador seja bem-sucedido, rompendo com as barreiras do método convencional.

Evidenciada a dificuldade, na prática cotidiana do profissional de saúde, de perceber os detalhes e dinâmicas de trabalho e vida da população rural, torna-se fundamental que o projeto em análise busque a realização de atividade que possibilitassem uma aproximação com as famílias de agricultores. Somente assim, qualquer prática proposta atingirá com viabilidade o funcionamento. Ademais, uma vez integrados a dinâmica dessas famílias, pode-se então realizar a ampliação da percepção de riscos pelos trabalhadores agrícolas. Dessa forma, ao estimular uma visão ativa dessa população, tornam-se esses indivíduos mais críticos ao seu próprio meio e hábitos.

Não obstante, em relação aos acidentes de trabalho na população rural muito ainda há de ser feito. Atualmente, o SUS gere as notificações através do DATASUS contabilizando acidentes e incidentes de todo país. Acontece, contu- 
do, que apesar do elevado número de casos relatados, uma importante parcela ainda não chegue aos registros oficiais. Denota-se, portanto, que qualquer análise ou política de saúde estabelecida a partir desses dados deve levar em conta uma importante subnotificação.

\section{CONSIDERAÇÕES FINAIS}

Ao analisarmos os aspectos gerais do projeto em questão, podemos compreender algumas das dificuldades enfrentadas pelos profissionais da saúde quanto promotores da saúde. Dentre eles o analfabetismo e baixa instrução de boa parte da população rural e a dificuldade da penetração do agente de saúde em áreas mais remotas. Além disso, em relação aos profissionais, a não percepção dos reais riscos da atividade agrícola, assim como a dificuldade de realizar a educação para saúde em vista da problemática adequação do vocabulário e técnica comunicativa para com a população rural. Ademais, a dificuldade de uma notificação eficiente dos acidentes de trabalho.

Outrossim, o projeto evidenciou o efeito extremamente benéfico da formação dos agentes que serão o ponto chave da educação para saúde. Não obstante, os resultados do processo de formação ficaram evidenciados pela quantidade e qualidade dos materiais educativos produzidos pelos profissionais. Por conseguinte, as ações de educação para saúde tiveram mais subsídios para acontecer e as ações tornaram-se potencialmente mais efetivas.

\section{REFERENNCIAS}

PROJETO VIDA E SAÚDE NO CAMPO: TECNOLOGIAS EDUCATIVAS DESPERTANDO CONSCIÊNCIAS. Fundação Oswaldo Cruz (FIOCRUZ,2005). Disponível em: www.ensp.fiocruz.br/saudenocampo. Acessado em 20 mai 2020.

FERNANDES, M.C.P; BACKES, V.M.S. Educação em saúde: perspectivas de uma equipe da Estratégia Saúde da Família sob a óptica de Paulo Freire. Rev. Brasileira de Enfermagem, n. 63, v. 4, 567-73, 2010. 
REZENDE, LA; STRUCHINER, M. Uma Proposta Pedagógica para Produção e Utilização de Materiais Audiovisuais no Ensino de Ciências: análise de um vídeo sobre entomologia. Alexandria: Revista de Educação em Ciência e Tecnologia. 2009. UFSC, Florianópolis, Santa Catarina, Brasil

WAYHS RI. Ressignificando o sofrimento cotidiano da família da criança e do adolescente com o diagnóstico de câncer a partir de uma prática cuidativa-educativa problematizadora [dissertação].Florianópolis: Programa de Pós-Graduação em Enfermagem, Universidade Federal de Santa Catarina; 2003.

OLIVEIRA HM, GONÇALVES MJF. Educação em saúde: uma experiência transformadora. Revista Brasileira de Enfermagem, n. 54, v. 6, 2004.

GAZZINELLI, MF; GAZZINELLI, A; REIS, DC; PENNA, CMM. Educação em saúde: conhecimentos, representações sociais e experiências da doença. Cad. Saúde Pública, Rio de Janeiro, v. 21, 2005.

COSCRATO, G; BUENO, SMV. Concepção de enfermeiros de uma rede pública de saúde sobre Educação para a Saúde. Revista da Escola de Enfermagem, v. 47, 2013.

PIRES, EG. A experiência audiovisual nos espaços educativos: possíveis interseções entre educação e comunicação. Educação e Pesquisa, v. 36, jan/abril de 2010.

SALCI, MA; MACENO, P; ROZZA, SG; SILVA, DMGV; BOEHS, AE; HEIDEMANN, ITSB. Educação em saúde e suas perspectivas teóricas: algumas reflexões. Texto Contexto Enferm, Florianópolis, v. 22, jan/mar 2013.

WERNER, W. What Does This Picture Say? - Reading About thelntertextuality of Visual Images. International Jounal Soc Education, v.19, n.1, 2004.

DA SILVA SANTOS, Álvaro Educação em saúde: reflexão e aplicabilidade em atenção primária á saúde. Online Brazilian Journal of Nursing. n. 5, v. 2, 2006. Disponível: https://www.redalyc.org/articulo.oa?id=361453972029. Acessado em 15 nov 2021. 


\title{
dol $10.48209 / 978-65-S A U D E-43-8$
}

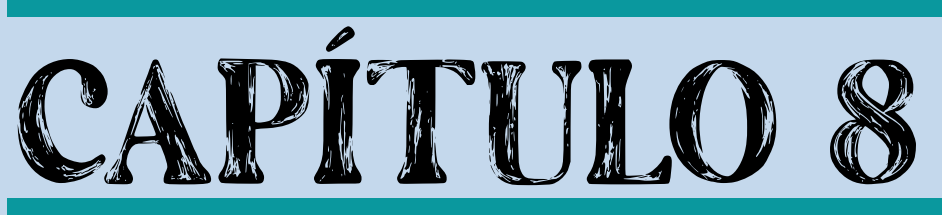

\section{BREVE ANÁLISE DO PROJETO DE EDUCAÇÃO POPULAR EM SAÚDE LGBT NOS POSTOS DE SAÚDE EM GOIÂNIA}

\author{
Bruna Luísa Küster \\ Gabriel Delai de Freitas \\ Vinicius do Nascimento Rodrigues
}




\section{INTRODUÇÃO}

O recorte populacional formado por Lésbicas, Gays, Bissexuais, Travestis e Transexuais (LGBT) ainda hoje é alvo de preconceitos e demais violências que possam se associar ao fato de viverem sexualidades de modos diferentes das normas historicamente constituídas. Destaca-se, contudo, que a homossexualidade foi retirada dos manuais de doenças mentais por entidades médicas e governamentais, desde 1984.

Assim, começaram a surgir políticas públicas, ações e programas voltados para tais sujeitos, como a Política Nacional de Saúde Integral de Lésbicas, Gays, Bissexuais, Travestis e Transexuais (PNSI LGBT), publicada em 2012. Entende-se que este foi um grande passo em busca de maior equidade no Sistema Único de Saúde (SUS), com o objetivo de promover saúde integral da população LGBT, já que busca eliminar a discriminação e o preconceito institucional, reduzindo desigualdades. Observa-se, todavia, que entre a previsão legal e sua efetiva materialização, há diversos problemas que geram exclusão social no campo da saúde pública (MORAES et al., 2020, p. 2; BRASILIA, 2013).

Nesse viés, a Educação em Saúde é o processo educativo de conhecimentos em saúde, visando à apropriação temática pela população. Dessa forma, é o conjunto de práticas do setor que contribui para aumentar a autonomia das pessoas no seu cuidado, bem como no debate com os profissionais e gestores, a fim de alcançar uma atenção de saúde, conforme suas necessidades. (MINISTÉRIO DA SAÚDE, 2013). A população LGBT, sobretudo a população de transexuais e travestis, vem promovendo formas de organização que buscam incorporar as demandas desses segmentos socias às políticas públicas.

No entanto, apesar do viés legal, algumas populações ainda enfrentam limitações e desafios de acesso e de garantia aos seus direitos fundamentais, principalmente no quê se relaciona com a promoção, proteção e recuperação de sua saúde. Sob essa análise, é possível perceber os inúmeros desafios que são 
enfrentados diariamente pela população trans - transexuais, travestis e transgêneros - no que diz respeito à garantia do acesso universal ao SUS.

O estudo de Rocon et. al. (2020), aborda os sete principais desafios enfrentados pela população em discussão: (1) a discriminação nos serviços e equipamentos de saúde; (2) a patologização da transexualidade, (3) o acolhimento inadequado; (4) a exigência de cirurgia; (5) a qualificação dos profissionais; (6) a ausência de política de atenção básica e inexistência de rede de saúde; e (7) a escassez de recursos para o financiamento dos processos transexualizadores e de políticas de promoção da equidade e respeito às identidades de gênero trans.

Partindo disto, ainda que haja engajamento de grandes órgãos da saúde em relação ao enfrentamento das discriminações, o preconceito consolidado socialmente e que influencia profissionais de saúde, pode se tornar uma barreira ao acolhimento considerado ideal. Ainda, a falta de conhecimento sobre questões importantes de sexualidade e gênero torna o acolhimento de pessoas trans um desafio na rede básica de saúde, visto que esta população é historicamente estigmatizada e marginalizada por se diferenciar dos padrões impostos como normas acerca da identidade de gênero (SILVA, et al. 2017).

Ademais, sabe-se que nossa sociedade opera numa lógica binária, que a divide sempre em polos opostos. O que flui entre os polos, ou então escapa deles, não é tido como legitimado e, se mesmo assim, as tecnologias de controle não conseguirem normalizá-lo, ele será colocado na margem, sendo, dessa forma, esquecido (ZOTTI, 2018, p.8).

A partir disso, o presente trabalho disserta sobre um Projeto de Educação em Saúde realizado em Postos de Saúde no município de Goiânia - GO, o qual tem como público-alvo a população LGBT local, sobretudo, as travestis e transexuais, em agosto de 2016. A ideia é promover uma discussão que acione novas ideias e ações acerca de medidas de educação em saúde que sejam relevantes para a população em destaque. 


\section{A ATENÇÃO BÁSICA COMO PORTA DE ENTRADA PARA A POPULAÇÃO LGBT}

O preconceito e a discriminação aos comportamentos sexuais divergentes do padrão heterossexual são reconhecidos na literatura como determinantes de saúde, visto que provocam vulnerabilidades, assim como constituem barreiras ao acesso, influenciam a qualidade da atenção, e carregam forte potencial para desencadear processos de sofrimento, adoecimento e morte prematura desta população. Ainda, o Artigo 196 da Constituição Federal de 1988 (BRASIL, 2020) define a saúde como direito de todos e dever do Estado, o qual deve garantir o acesso universal e igualitário às ações e aos serviços de promoção, proteção e recuperação da saúde. No entanto, algumas populações ainda enfrentam cotidianamente os desafios de acesso e a garantia de promoção, proteção e recuperação de sua saúde, como é o caso da população trans (ROCON et al, 2020).

Sendo assim, as Unidades Básicas de Saúde (UBS), em especial quando contam com a Estratégia de Saúde da Família (ESF), representam os espaços ideais para a implementação das ações oriundas de políticas públicas dirigidas à equidade. Todavia, são diversos desafios para a reorganização de serviços, protocolos e rotinas na Atenção Básica, sob a perspetiva de superação da discriminação e preconceito e da prática da integralidade e equidade, o que exige dos sujeitos, da coletividade e das instituições.

\section{O ATENDIMENTO À POPULAÇÃO LGBT E A NECESSIDADE DEMOVIMENTOS DE EDUCAÇÃO EM SAÚDE}

O atendimento na Atenção Básica deve respeitar seus princípios fundamentais, levando em conta a singularidade, inserção cultural, os determinantes e condicionantes sociais da saúde da população, uma vez que as ações devem convergir para a proteção, prevenção, recuperação e promoção da saúde. Dessa forma, deve-se haver esforços visando minimizar as desigualdades e exclusão de grupos sociais, atendendo a diversidade humana, sobretudo, a população LGBT. 
Nesse contexto, a Atenção Básica tem se apresentado como uma ferramenta fundamental para o processo de educação e difusão de informações qualificadas, as quais auxiliam no processo de conscientização da população. Sendo assim, as necessidades específicas e os desafios enfrentados pela população LGBT exigem preparo, uma vez que a falta de treinamento pode perpetuar o preconceito e a discriminação, acarretando cuidados de baixa qualidade e aumento na incidência de doenças e seus fatores de risco, sendo assim, deve-se investir na educação profissional e em diretrizes práticas, para que se tenha uma oferta ampla e abrangente, científica e, sobretudo, humana a esse grupo populacional.

Conforme apontado anteriormente, Educação em Saúde é o processo educativo de conhecimentos em saúde que almeja a apropriação temática pela população. Dessa forma, é o conjunto de práticas do setor que contribui para aumentar a autonomia das pessoas no seu cuidado, bem como no debate com os profissionais e gestores, a fim de alcançar uma atenção de saúde, conforme suas necessidades. (MINISTÉRIO DA SAÚDE, 2013). Em vista disso, a população LGBT, sobretudo a população de transexuais e travestis, está promovendo formas de organização que buscam incorporar suas demandas às políticas públicas, que são essenciais para gestão e manutenção de seus direitos básicos, incluindo o direito a saúde e a sua integração a atenção básica, possibilitando um atendimento mais amplo e integral.

A vulnerabilidade da população LGBT, o direito ao acesso universal e gratuito à saúde, assegurado pela Constituição, assim como as diretrizes do Sistema Único de Saúde (SUS) e o papel da Atenção Básica, são aspectos necessários para o cuidado desta população. Além disso, deve-se refletir e acrescentar nas pautas de debates sobre esta temática, tanto na formação quanto nas atividades de educação permanente nos serviços de saúde, bem como nos eventos científicos e acadêmicos, visando considerar a especificidade do contexto de saúde e de vida das pessoas LGBT, ampliando a conversação e compartilhando os saberes necessários às práticas de cuidado a serem incorporadas no cotidiano da Atenção Básica. 


\section{O PROJETO DE EDUCAÇÃO POPULAR EM SAÚdE LGBT NOS POSTOS DE SAÚDE EM GOIÂNIA-GO}

O trabalho submetido na Semana da Saúde da população LGBT, em agosto de 2016, em Goiânia-GO, buscou compreender as limitações encontradas pela gestão e pelos profissionais no atendimento da população LGBT. A intervenção, nesse contexto, se configura como uma ação de educação em saúde, uma vez que buscou determinar os fatores sociais que implicam em preconceitos e falta de acesso à saúde orientados pelas denúncias e pelas vivências desses usuários do sistema de saúde que sempre encontraram limitações no exercício de direitos básicos e que garantem a sua vida.

O objetivo primordial dessa atividade foi fazer com que as trocas de experiências desenvolvidas em minicursos pudessem proporcionar um efeito transformador na prática das relações profissional-usuário. Desse modo, as intervenções foram realizadas em 15 postos de saúde em que eram iniciadas com uma abertura que buscava atrair a atenção dos participantes e subsequentemente, a realização de uma discussão sobre os princípios das políticas do SUS e a sua relação com a atenção a saúde LGBT e uma reflexão sobre os empecilhos encontrados por essa população na procura dos serviços de saúde, expostos por relatos dos usuários sobre situações de preconceito e exclusão vivenciados dentro do sistema de saúde. Por fim, houve a distribuição de folders e cartilhas elaborados pelo movimento social LGBT.

Logo, o protagonismo da população LGBT como o foco principal do desenvolvimento das ações intervencionistas, resultou em uma experiência que permitiu a construção de um direcionamento diferenciado na qualidade da relação entre os profissionais de saúde e os usuários pertencentes a essa população. Assim, a desconstrução de um atendimento unilateral e a potencialização de uma abordagem que considera a diversidade e as especificidades presentes em cada sujeito reorganização dos serviços de saúde pública ao trazerem novas demandas e necessidades para que o direito à saúde seja instituído de forma plena. 
O projeto é uma intervenção de educação em saúde de grande relevância, pois se dispõe a compreender as especificidades da população LGBT, a partir das vivências dos indivíduos que compõem a sigla. Dessa forma, ao conhecer a realidade do objeto de intervenção e compartilhar técnicas de abordagem com aqueles que vivenciam a realidade a ser abordada é possível os aproximar do sistema de atenção básica em saúde, romper com estigmas pré-estabelecidos por senso comum e sem embasamento científico. Ademais, ao tornar o público alvo um elemento de protagonismo inserido no seu contexto de saúde é possível desenvolver um maior senso de responsabilidade e participação construtiva dentro da comunidade.

\section{CONSIDERAÇÕES FINAIS}

A educação em saúde não deve ser encarada apenas como um repasse de informações, sendo, dessa forma, uma união de tempo e energia. Nesse viés, a atividade educacional foi de suma importância, uma vez que aproximou o conhecimento do modo de vida das pessoas, além de desmistificar os saberes e tudo que permeia e o cotidiano do objeto da educação popular e da saúde LGBT. É fundamental, nos processos de educação em saúde, colocar em destaque as experiências vividas pelos usuários e com elas, trabalhar para que estas sejam reproduzidas, se boas, ou corrigidas, se ruins forem.

As informações são captadas por meio de todos os sentidos, seja auditivo, visual, olfativo, sinestésico ou gustativo, sendo necessário identificarmos qual o sentido mais disponível e, assim, nos postos de saúde foram utilizados de forma simples e resumida os instrumentos que convidariam as pessoas a acreditar no cuidado ao outro como ele é, encorajando as pessoas a questionar os problemas do cotidiano, bem como se tornarem capazes de realizar ações em saúde e que valorize suas próprias experiências e o atendimento humanizado.

Conforme apontam Albuquerque, Botelho e Rodrigues (2020), embora iniciativas mundiais e nacionais como a Política Nacional de Atenção Integral à 
Saúde da População LGBT do Ministério da Saúde, preconizam a qualificação e discussão dessa temática no âmbito da saúde e educação, o tema ainda é marginalizado e excluído das grandes discussões, sobretudo, nas escolas médicas e na atenção básica, a qual é o primeiro contato do usuário com o Sistema Único de Saúde.

Além disso, conforme os autores, deve-se planejar e reformular a política de cuidados a grupos vulneráveis, como as minorias, visto que necessita ser prioridade nas instituições formativas e assistenciais em saúde. Algumas mudanças são sutis e facilmente aplicáveis, como a mudança do vocabulário e o olhar integral do paciente. No entanto, outras são mais profundas, bem como transformações culturais, que implicam em modificações nas práticas educacionais vigentes.

\section{REFERENCIAS}

ALBUQUERQUE, Mário Roberto Tavares Cardoso de, BOTELHO Nara Macedo, RODRIGUES Cybelle Cristina Pereira. Atenção integral à saúde da população LGBT: Experiência de educação em saúde com agentes comunitários na atenção básica. Revista Brasileira de Medicina da Familia e Comunidade. 2019, n. 14, v. 41. Disponível em: https://doi.org/10.5712/rbmfc14(41)1758. Acesso em 01 jun 2021.

BRASIL. Constituição (1988). Constituição da República Federativa do Brasil de 1988. Brasília, DF: Presidência da República, 2020. Disponível em: <www.planalto.gov.br/ccivil_03/constituicao/constituicao.htm>. Acesso em: 02 de junho de 2021

BRASÍLIA, Política Nacional de Saúde Integral de Lésbicas, Gays, Bissexuais, Travestis e Transexuais. Brasília: Ministério da Saúde; 2013. Disponível em: http://bvsms.saude.gov.br/bvs/publicacoes/politica_nacional_saude_lesbicas_ gays.pdf. Acesso em 01 jun 2021.

FERNANDES, Beth. Educação Popular em Saúde LGBTT: um diálogo da sociedade cívil com os Postos de Saúde em Goiânia. Tempus, actas de saúde colet, Brasília, n. 11, v. 1, 2017. 
GUIMARÃES, Rita de Cássia Passos, et. al. Assistência à saúde à população LGBT em uma capital brasileira: o que dizem os Agentes Comunitários de Saúde?. Tempus, actas de saúde coletiva, n.. 11, v. 1, Disponível em http://dx.doi. org/10.18569/tempus.v11i1.2327. Acesso em 10 de junho de 2021.

HOFFMANN, Celina, et al. Prazer e sofrimento no trabalho docente: Brasil e Portugal. Educação e Pesquisa, São Paulo, v. 45, 2019. Disponível em: <https:// www.revistas.usp.br/ep/article/view/162454>. Acesso em: 23 de maio de 2021.

MINISTÉRIO DA SAÚDE. Secretaria de Gestão Estratégica e Participativa. Departamento de Apoio à Gestão Participativa. Caderno de educação popular e saúde / Ministério da Saúde, Secretaria de Gestão Estratégica e Participativa, Departamento de Apoio à Gestão Participativa. - Brasília: Ministério da Saúde, 2007.

MINISTÉRIO DA SAÚDE. Secretaria de Gestão do Trabalho e da Educação na Saúde. Departamento de Gestão da Educação na Saúde. Política Nacional de Educação Permanente em Saúde: o que se tem produzido para o seu fortalecimento? Ministério da Saúde, Secretaria de Gestão do Trabalho e da Educação na Saúde, Departamento de Gestão da Educação na Saúde, Brasília : Ministério da Saúde, 2018.

MORAIS, Antônio Carlos de et al. Ensino em Saúde LGBT na Pandemia da Covid-19: Oportunidades e Vulnerabilidades. Revista Brasileira de Educação Médica [online]. 2020, v. 44. Disponível em: <https://doi.org/10.1590/1981-5271v44. supl.1-20200423>. Acesso em 13 nov 2021.

NETO Antônio Carlos de Morais, et al. Ensino em Saúde LGBT na Pandemia da Covid-19: Oportunidades e Vulnerabilidades. Revista Brasileira de Educação Médica, 44 (sup. 1): e0157, 2020. DOI: https://doi.org/10.1590/1981-5271v44.supl.120200423.

SANTOS, Juliana Spinula dos, SILVARodrigo Nogueira da, FERREIRA Márcia de Assunção. Saúde da População LGBTI+ na Atenção Primária à Saúde e a Inserção da Enfermagem. Escola Anna Nery, n. 23, v. 4, 2019. Disponível em <https:// www.scielo.br/j/ean/a/dzYKmCyv3MTJN3ZXVRN75Kg/?lang=pt\&format=pdf>. Acesso em 01 de junho de 2021. 
VALE, Thais Campelo Bedê et al. Factors behind burnout increase in medical students: are the criteria so important?. Rev. bras. educ. med., Brasília , v. 45, n. 2, 2021. Disponível em:<http://www.scielo.br/scielo.php?script=sci_arttext\&pi$\mathrm{d}=\mathrm{S} 0100-55022021000200203 \& \mathrm{lng}=\mathrm{e}$ n\&nrm=iso>. Acesso em: 23 de maio de 2021.

VIANNA, Cláudia Pereira. O movimento LGBT e as políticas de educação de gênero e diversidade sexual: perdas, ganhos e desafios. Educação e Pesquisa, n. 241, v. 3, 2015. Disponível em: https://doi.org/10.1590/s1517-97022015031914. Acesso em: 23 de maio de 2021 
dol 10.48209/978-65-SAUDE-43-9

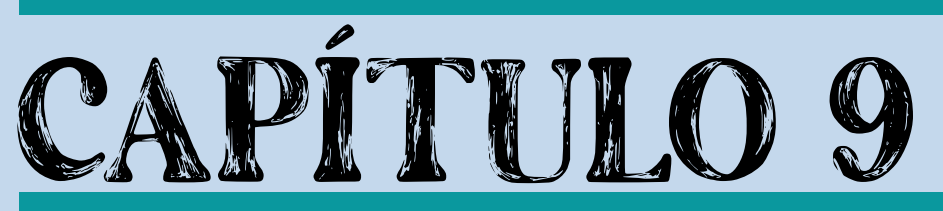

YOUTUBE E EDUCAÇÃO EM SAÚDE: UTILIZAÇÃO DO CANAL DRUGSLAB COMO UMA AÇÃO DE EDUCAÇÃO EM SAÚDE VOLTADA PARA ADOLESCENTES

Bruna Vendruscollo Rodrigues

Jéssica Fortunato Oliveira

Letícia Sehn Da Fonseca 


\section{INTRODUÇÃO}

A educação em saúde consiste em um processo educativo de construção de conhecimentos em saúde que visa à apropriação temática pela população por meio de práticas integrais, voltadas às reais demandas de uma população (BRASIL, 2007). Um dos inúmeros desafios relacionados à educação em saúde é levar a informação de forma clara, de qualidade e fácil acesso para a população (FALKENBERG et al, 2014).

Sabe-se, neste contexto, que o debate sobre o consumo de drogas é necessário em ações de educação em saúde. Essa temática torna-se ainda mais relevante com o público adolescente, por se tratar de um período de inúmeras transformações e tentativas de autoafirmação perante os grupos em que diferentes adolescentes se inserem, havendo um maior desejo de experimentar o novo, podendo culminar, consequentemente, no consumo de drogas (CAVALCANTE et al, 2008, FEFFERMANN, FIGUEIREDO, 2006).

Assim, o presente texto tem por objetivo analisar o canal do YouTube intitulado "DrugsLab", criado pela emissora pública holandesa BBN, como um projeto de educação em saúde sobre a temática das drogas para o público adolescente com a finalidade de compreender como o mesmo poderia funcionar como uma ferramenta de educação em saúde.

Partindo disso, nas seções que seguem, estão a metodologia, os tópicos "Drogas e Adolescência”, "Educação em Saúde e o YouTube como Ferramenta de Apoio" e "O Canal DrugsLab como um Projeto de Educação em Saúde" e, por fim, as considerações finais.

\section{METODOLOGIA}

Foi realizada uma análise documental sustentada por uma revisão bibliográfica. A análise documental busca examinar e compreender o teor de documentos, bem como obter informações significativas de acordo com os objetivos 
de pesquisa previamente estabelecidos, através de procedimentos técnicos e científicos para esse fim (JUNIOR et al, 2021).

Ainda, conforme Sá-Silva, Almeida e Guindani (2009) a análise documental consiste em "[...] um procedimento que se utiliza de métodos e técnicas para a apreensão, compreensão e análise de documentos dos mais variados tipos" (p. 5). Dessa maneira entende-se que a análise documental não necessita ser limitada a apenas a textos, podendo também ser desenvolvida através de materiais como fotos, vídeos e postagens em mídias sociais, por exemplo.

Para a seleção dos textos utilizados, realizou-se levantamento bibliográfico na base de dados Google Acadêmico. Em um primeiro momento foram utilizadas as palavras chave "DrugsLab" e "YouTube" buscando publicações sobre o referido canal do YouTube. Após, foram utilizadas as palavras chave "Drogas", "Educação" e "Adolescência”, em busca de publicações acerca da temática das drogas na adolescência, bem como o papel da educação, sendo encontrados diversos resultados. Desses, foram escolhidos 8 textos para a leitura. Posteriormente, foram utilizadas as palavras chave "YouTube" e "Educação", a fim de selecionar textos sobre o papel da plataforma na educação. Por fim, foi utilizado o termo "Educação em Saúde" visando encontrar publicações sobre a temática.

Após o levantamento bibliográfico, 20 textos foram selecionados, sendo que destes, 6 foram excluídos por não se mostrarem compatíveis com a temática do trabalho. Por fim, foi realizada uma nova leitura cuidadosa dos trabalhos, buscando uma compreensão global dos conteúdos, bem como a abstração das ideias centrais de cada texto.

\section{DROGAS E ADOLESCENCIA}

O conceito de droga é amplo com diferentes significados. Pela perspectiva popular, entende-se que droga é qualquer substância psicoativa, usualmente considerada ilegal. Já, para a medicina, as drogas são substâncias capazes de prevenir ou curar uma enfermidade ou aumentar a saúde física ou mental de um 
indivíduo (ROMERO, 2019, FONTE, 2006). Por fim, a Organização Mundial da Saúde (OMS), define como droga "toda a substância que, pela sua natureza, afeta a estrutura e funcionamento do organismo" (FONTE, 2006).

Independentemente de sua definição, segundo Bucher (2002), "ao percorrermos a história da civilização, encontramos a presença de drogas, desde os primórdios da humanidade, inseridas nos mais diversos contextos: social, econômico, medicinal, religioso, ritual, cultural, psicológico, estético, climatológico e, mesmo, militar" (p. 6) . Nesse viés, é possível também afirmar que, ao longo da história, os fatores que vêm diferenciando a legalidade ou ilegalidade das drogas seriam, sobretudo, interesses econômicos e políticos, e não razões puramente ligadas à saúde (FEFFERMANN, FIGUEIREDO, 2006). Ainda, ao analisar dados de morbidade e mortalidade de diversos países, é possível afirmar que drogas legais no ocidente, como o álcool e o tabaco, mostram-se tão ou até mais prejudiciais à saúde da população quanto as consideradas ilegais, devendo, assim, também serem consideradas em ações de prevenção e tratamento (FEFFERMANN, FIGUEIREDO, 2006).

Neste contexto, é importante que o tema seja aproximado à realidade de grupos específicos, de modo a serem pensadas dinâmicas de ação em saúde acerca do controle e prevenção do uso de drogas. Partindo de uma definição por meio de faixa, os adolescentes podem compor um desses grupos. A adolescência, mais do que uma faixa etária de transformação de infância para a vida adulta, é um período crítico na vida de cada indivíduo na qual é feita a afirmação de sua personalidade e individualidade, bem como diversas outras descobertas significativas (SILVA et al, 2010, SILVA, PADILHA 2013). Além disso, é nessa fase que o adolescente busca a sensação de pertencimento em um grupo, que influenciará suas ações e também pode levar o adolescente a adotar atitudes que provem seu pertencimento ao coletivo (SILVA et al, 2010). Assim, nesse período da vida, o grupo de amigos atinge a importância principal, enquanto há uma tendência de os conflitos familiares atingirem o seu ápice, devido a busca natural do adolescente em apresentar uma imagem de adulto independente diante de seu grupo, 
podendo essa crise, bem como o desejo de experimentar o novo característico da adolescência, resultar no consumo de drogas (CAVALCANTE et al, 2008, FEFFERMANN, FIGUEIREDO, 2006)

Além da crise entre a entidade familiar e o grupo de amigos, diversos outros fatores podem ser relacionados com o uso de drogas, legais ou ilegais por adolescentes. Fatores sociodemográficos, como sexo, idade e classe social parecem ter influência, assim como a percepção de relacionamento familiar, o envolvimento parental - familiar ou de algum amigo com drogas -, a ausência de prática religiosa e a baixa prática de esportes. Ainda, pode-se afirmar que os meios de comunicação e as normas sociais também podem estimular hábitos de consumo de drogas na adolescência por meio da normalização de conceitos como "beber socialmente", bem como da ideia de utilização de álcool como um "rito de passagem" para a vida adulta. Por fim, a grande disponibilidade, principalmente das drogas lícitas, em estabelecimentos comerciais, assim como a falta de uma fiscalização adequada que, de fato, restrinja a compra e o consumo de álcool e tabaco por menores de 18 anos de idade, também é um fator que predispõe o consumo de drogas por adolescentes (CAVALCANTE et al, 2008).

\section{EDUCAÇÃO EM SAÚdE E 0 YOUTUBE COMO FERRAMENTA DE APOIO}

O YouTube consiste em uma plataforma de vídeos que proporciona a disseminação de diversas informações, de maneira clara e de fácil acesso à população geral quando bem utilizada. Por essas características, a plataforma de vídeos pode ser considerada como uma ferramenta no processo de educação em saúde.

O Ministério da Saúde define a educação em saúde como processo educativo de construção de conhecimentos em saúde que visa à apropriação temática pela população. Ainda, como uma conjunto de práticas do setor que contribui para aumentar a autonomia das pessoas no seu cuidado e no debate com os 
profissionais e os gestores a fim de alcançar uma atenção de saúde de acordo com suas necessidades. (BRASIL, 2006).

Para que a educação em saúde ocorra, é necessária a correlação de três principais agentes: os profissionais de saúde, os gestores, e a população (FALKENBERG et al, 2014). Cabe aos primeiros a valorização, prevenção e promoção de saúde e a realização de práticas curativas, aos segundos apoiar os profissionais da saúde e aos terceiros a construção de conhecimentos que busquem aumentar a sua autonomia nos cuidados individuais e coletivos de saúde (FALKENBERG et al, 2014).

Ainda, a educação em saúde requer um pensar crítico e reflexivo que permita o conhecimento sobre a realidade apresentada e que proponha ações que levem o indivíduo a ser capaz de opinar em suas decisões de saúde (BESEN et al, 2007, MENDONÇA, NUNES, 2015). Por fim, a educação popular em saúde é voltada para a promoção de práticas integrais, voltadas às reais demandas de uma população, sendo pautada pela participação e comunicação com a comunidade na qual está sendo desenvolvida (BESEN et al, 2007, FALKENBERG et al, 2014).

A educação em saúde passa por inúmeros desafios, sendo um deles é levar a informação de forma clara, de qualidade e fácil acesso. Para isso, podemos citar plataformas como o Youtube como um veículo para a educação em saúde, por se tratar de uma ferramenta potente na pedagogia devido ao seu dinamismo, fácil acesso e livre produção de conteúdo. Ainda, a utilização de vídeos em prol da aprendizagem tem o poder de atrair estudantes, o que favorece o aumento da qualidade do conhecimento, sendo que que a possibilidade da utilização de recursos audiovisuais com escritas, imagens e sons por meio da plataforma engrandece a potência de ensino, podendo melhorar a aprendizagem e criar uma expectativa positiva do aluno pela aula (OLIVEIRA, 2016).

A educação em saúde como processo político pedagógico requer o desenvolvimento de um pensar crítico e reflexivo, permitindo desvelar a realidade e 
propor ações transformadoras que levem o indivíduo à sua autonomia e emancipação como sujeito histórico e social, capaz de propor e opinar nas decisões de saúde para cuidar de si, de sua família e de sua coletividade (FALKENBERG et al, 2014). Embora plataformas como o Youtube ofereçam fácil acesso, para a educação em saúde pode haver mais desafios e barreiras uma vez que mesmo havendo a possibilidade de livre produção de conteúdo, os mesmos são mediados por regras as quais os algoritmos da plataforma obedecem.

Em relação às drogas, o Youtube, em sua política de conteúdo, as enquadra como conteúdo violento ou perigoso, o que proíbe: exibição de uso de drogas pesadas, de conteúdo não educacional que mostra a injeção de drogas intravenosas, como heroína ou cheirando cola; fabricação de drogas pesadas, com conteúdo não educacional que explica como fabricar drogas; menores usando álcool ou drogas, usando vaporizadores, cigarros eletrônicos, tabaco ou maconha; vendendo drogas pesadas ou leves e se houver links na descrição que direcionam à venda de drogas o canal será encerrado (OLIVEIRA, 2016). Entretanto, se o conteúdo for considerado educacional, como em casos de documentário, trabaIhos científicos ou artísticos relacionados à temática, o mesmo será restrito por idade (OLIVEIRA, 2016).

Apesar da existência do adendo aos conteúdos educacionais previsto pela política da plataforma, canais que produzem conteúdos educativos frequentemente relatam que seus conteúdos foram bloqueados de publicações, suas postagens e vídeos removidos e suas contas suspensas ou banidas. Dessa forma, pode-se afirmar que, muitas vezes, o próprio algoritmo da plataforma acaba por gerar um efeito negativo na educação em saúde ao restringir vídeos e canais que realizam ações nesse sentido (OLIVEIRA, 2016).

\section{CANAL DRUGSLAB COMO UM PROJETO DE EDUCAÇÃO EM SAÚDE}

O canal do YouTube "DrugsLab", criado pela emissora pública holandesa BBN em 2017 objetiva, por meio de explicações sobre práticas de uso mais se- 
guras, instruções de dosagem, informações sobre os efeitos e riscos do uso de diversas substâncias - tanto lícitas quanto ilícitas - prestar um serviço de informação e redução de danos aos jovens que possuem curiosidade de experimentar drogas ou que já as consomem. (FRIEDRICH, 2018, BARIFOUSE, 2017). Os episódios, com duração média de 10 minutos cada, exibem informações sobre os efeitos da droga em questão no corpo e na mente no início do episódio, sendo seguido por um teste em câmera, no qual um dos apresentadores consome a droga e o segundo apresentador atua como um acompanhante, atento às reações do usuário e pronto para intervir se necessário (FRIEDRICH, 2018, BARIFOUSE, 2017).

Além das reações comportamentais do usuário registradas pela câmera, também são avaliadas em cada episódio a temperatura corporal, frequência cardíaca, habilidades motoras e cognitivas do apresentador sob a influência da substância testada durante o episódio. Todas as drogas - lícitas ou ilícitas - consumidas nos episódios da série são previamente testadas quanto sua composição por laboratórios autorizados pelo Ministério de Saúde da Holanda - processo que pode ser realizado anonimamente no país (BARIFOUSE, 2017). Além disso, um paramédico está disponível no set de filmagem de todos os episódios, podendo intervir em caso de quaisquer emergências (FRIEDRICH, 2018).

Nesse ínterim, a Lei $n^{\circ} 11.343 / 2006$, “A Lei de Drogas do Brasil”, em seu Título III, discorre acerca da promoção e fortalecimento dos fatores de proteção como forma de prevenção do uso indevido de tais drogas. É neste sentido que as práticas de educação para saúde se encaixam, pois, é visto que uma discussão acerca de políticas sobre drogas no Brasil não pode se restringir apenas aos seus marcos legais, tendo em vista que na adolescência não somente essa esfera irá influenciar na posição dos jovens acerca do assunto (BARBOSA, BICALHO, 2014)

Por isso, é imprescindível também incluir nesta discussão outros fatores que exercem grande influência na formação de opiniões dos jovens, como os discursos disseminados pela mídia, internet e até mesmo entre acadêmicos, pois 
mesmo que essas opiniões não constem em documentos oficiais, são de grande relevância. Segundo Barbosa e Bicalho (2014), esses eventos podem se mostrar de grande potência na materialização de lógicas vigentes na realidade nacional, tendo em vista que a imagem do policial muitas vezes traz à tona as características muito rígidas nas políticas sobre drogas da atualidade brasileira, o que acaba distanciando o jovem. Ainda, também de acordo com o exposto por Barbosa e Bicalho (2014), existe uma nítida separação entre as agências penais do Estado, sendo que, enquanto o discurso das leis afirma-se defensor dos principais interesses e valores da sociedade, as ações práticas estão vigorosamente comprometidas com o exercício de uma violência dita de exceção mas que mostra-se, contudo, permanente.

Assim, se considerarmos as práticas de educação em saúde como uma forma de elucidar, em parceria com a comunidade, mesmo que virtualmente, os malefícios do uso de drogas na adolescência, estamos também desvinculando a violência das práticas antidrogas, ou seja, é onde o canal DrugsLab se encaixa. Por outro lado, segundo o Art. 33. da Lei $n^{\circ} 11.343 / 2006$, constitui crime:

Art. 33. Importar, exportar, remeter, preparar, produzir, fabricar, adquirir, vender, expor à venda, oferecer, ter em depósito, transportar, trazer consigo, guardar, prescrever, ministrar, entregar a consumo ou fornecer drogas, ainda que gratuitamente, sem autorização ou em desacordo com determinação legal ou regulamentar. (BRASIL, 2014, s/n)

Nas mesmas penas incorre aquele que induzir, instigar ou auxiliar alguém ao uso indevido de drogas (sujeito à pena - detenção, de 1 a 3 anos, e multa de 100 a 300 dias-multa). A associação de pessoas, o financiamento e a colaboração como informante para prática dos atos descritos também configuram crime, assim como a prescrição ou administração de drogas (podendo chegar a 15 anos de detenção).

Dessa forma, pode-se perceber que, ao mesmo passo que o intuito principal do canal DrugsLab se manifesta educativo e informacional, no que se refere à redução de danos gerados pelas substâncias, levanta-se uma questão polêmica e dicotômica associada à abordagem utilizada pelos responsáveis, pois a 
utilização dessas substâncias em frente à uma câmera pode de certa forma estimular e auxiliar o uso indevido das drogas apresentadas pelos jovens "youtubers" holandeses.

Assim, entende-se que, ao considerar o conceito de educação em saúde, o canal DrugsLab se enquadra, de fato, como um projeto de educação em saúde que poderia ser utilizado na abordagem da temática das drogas com adolescentes. Contudo, seria interessante não utilizá-lo sozinho, justamente pela possibilidade do mesmo poder, de certa forma, estimular o uso indevido de drogas por despertar a curiosidade, sendo necessário aliar outra estratégia de educação que vise ampliar a reflexão acerca do conteúdo presente nos vídeos.

\section{CONSIDERAÇÕES FINAIS}

O YouTube é uma plataforma que pode ser de grande valia para a educação em saúde ao passo que proporciona um veículo para disseminação da informação de forma clara e de fácil acesso. Entretanto, muitas vezes o próprio algoritmo da plataforma acaba por restringir conteúdos educacionais relacionados às drogas por se tratar de um assunto controverso.

Nesse viés, o canal holandês DrugsLab pode ser compreendido como uma ação de educação em saúde sobre a temática das drogas para adolescentes, pois contribui para a busca do conhecimento ativo acerca da temática de uma maneira clara e de fácil acesso. Todavia, ressalvas devem ser feitas quanto à abordagem utilizada pelos criadores do canal, uma vez que a mesma pode, de certa forma, contribuir para o consumo de drogas, tanto lícitas quanto ilícitas, por adolescentes.

\section{REFERÊNCIAS}

ADADE, Mariana, MONTEIRO, Simone. Educação sobre drogas: uma proposta orientada pela redução de danos. Educação e Pesquisa [online]. 2014, v. 40, n. 1, pp. 215-230. Disponível em <https://www.scielo.br/j/ep/a/Gpq8xPVqgh3qXSy7LYqWhFL/abstract/?lang=pt\#>. Acesso em 14 mai. 2021. 
BARBOSA, Roberta Brasilino, DE BICALHO, Pedro Paulo Gastalho. O modo indivíduo nas políticas públicas sobre drogas no Brasil e as encomendas endereçadas à Psicologia / Individualization in public policies about drugs in Brazil and orders addressed to psychology. Revista Polis e Psique, Porto Alegre, RS, v. 4, n. 2, p. 230-249, dez. 2014. Disponível em <https://seer.ufrgs.br/PolisePsique/ article/view/51096>. Acesso em 14 mai. 2021.

BARIFOUSE, Rafael. O polêmico canal do YouTube em que apresentadores usam drogas para informar sobre efeitos e danos. BBC News Brasil, Londres, 26 jan. de 2017. Disponível em <https://www.bbc.com/portuguese/geral-38729393>. Acesso em 14 mai. 2021.

BESEN, Candice Boppré et al. A Estratégia Saúde da Família como objeto de educação em saúde. Saúde e Sociedade, São Paulo, v. 16, n. 1, p. 57-68, 2007. Disponível em <https://www.scielo.br/j/sausoc/a/RjFgLQMfk74GtQ6GCmkqRqK/?format=pdf\&lang=pt. Acesso em 14 mai. 2021.

BRASIL. Ministério da Saúde (MS). Secretaria de Gestão do Trabalho e da Educação na Saúde. Departamento de Gestão e da Regulação do Trabalho em Saúde. Câmara de Regulação do Trabalho em Saúde. Brasília: MS; 2006.

BRASIL. Ministério da Saúde. Secretaria de Gestão Estratégica e Participativa. Departamento de Apoio à Gestão Participativa. Caderno de educação popular e saúde. Brasília: MS, 2007.

BRASIL. Secretaria Nacional de Políticas sobre Drogas (Senado Federal). Práticas integrativas: na aplicação da lei no 11.343/2006: lei de drogas. Brasília: Ministério da Justiça, 2014. 160 p.

BUCHER, Richard. Visão Histórica e Antropológica das Drogas. In: FIGUEIREDO, R. (Org). Prevenção ao abuso de drogas em Ações de Saúde e Educação: uma abordagem sócio-cultural e de redução de danos. São Paulo, NEPAIDS/ USP, 2002.

CAVALCANTE, Maria Beatriz de Paula Tavares et al. Adolescência, álcool e drogas: uma revisão na perspectiva da promoção da saúde. Escola Anna Nery [online]. 2008, v. 12, n. 3, pp. 555-559. Disponível em <https://doi.org/10.1590/S1414$81452008000300024>$. Acesso em 14 mai. 2021. 
FALKENBERG, Mirian Benites et al. Educação em saúde e educação na saúde: conceitos e implicações para a saúde coletiva. Ciência \& Saúde Coletiva [online]. 2014, v. 19, n. 03, pp. 847-852. Disponível em <https://doi.org/10.1590/141381232014193.01572013>. Acesso em 14 mai. 2021.

FEFFERMANN, Marisa, FIGUEIREDO, Regina. Redução de danos como estratégia de prevenção de drogas entre jovens. BIS: Boletim do Instituto de Saúde, São Paulo, v. 40, 2006. Disponível em <https://docs.bvsalud.org/biblioref/2020/03/1050282/bis-n40-juventudes-e-vulnerabilidades-37-40.pdf>. Acesso em 14 mai. 2021.

FONTE, Carla. Comportamentos aditivos, conceito de droga, classificações de droga e tipos de consumo. Revista da Faculdade de Ciências e da Saúde do Porto, 3, 104 -112. 2006. Disponível em <https://bdigital.ufp.pt/bitstream/10284/533/1/ 104-112FCS2006-10.pdf>. Acesso em 14 mai. 2021.

FRIEDRICH, Adelheid. Neue digitale Wege der Erreichbarkeit von drogenkonsumierenden Menschen am Beispiel der App CheckPoint - C. Hochschulbibliothek, Hochschule Merseburg. 2018. Disponível em <http://dx.doi.org/10.25673/13696>. Acesso em 14 mai. 2021.

JUNIOR, Eduardo Brandão Lima et al. ANÁLISE DOCUMENTAL COMO PERCURSO METODOLÓGICO NA PESQUISA QUALITATIVA. Cadernos da FUCAMP, v. 20, n. 44, 2021. Disponível em <https://www.fucamp.edu.br/editora/index.php/cadernos/article/view/2356/1451>. Acesso em 14 mai. 2021.

MENDONÇA, Fernanda de Freitas e; NUNES, Elisabete de Fátima Polo de Almeida. Avaliação de grupos de educação em saúde para pessoas com doenças crônicas. Trabalho, Educação e Saúde [online]. 2015, v. 13, n. 2, pp. 397-409. Disponível em: <https://doi.org/10.1590/1981-7746-sip00053>. Acesso em 14 mai. 2021.

OLIVEIRA, Elaine Cristina, HARAYAMA, Rui Massato, VIÉGAS, Lygia de Sousa. Drogas e medicalização na escola: Reflexões sobre um debate necessário. Revista Teias. 2016; 17(45):99-118. In: Drogas, Medicalização e Educação. Disponível em <https://www.e-publicacoes.uerj.br/index.php/revistateias/article/ view/24598/17578>. Acesso em 14 mai. 2021 
OLIVEIRA, Priscila Patrícia Moura. O YOUTUBE COMO FERRAMENTA PEDAGÓGICA. Simpósio Internacional de Educação a Distância. São Carlos, 2016. Anais. São Carlos: UFSCAR. 2016. p. 1-14. Disponível em <http://www.siedenped2016.ead.ufscar.br/ojs/index.php/2016/article/view/1063> Acesso em 21 mai. 2021.

ROMERO, Lara García. Y hoy, ¿qué pillamos?: Programa de salud para la prevención del consumo de drogas en adolescentes. Universidad de Zaragoza. 2019. Disponível em <https://zaguan.unizar.es/record/89031\#>. Acesso em 14 mai. 2021.

SÁ-SILVA, Jackson Ronie; ALMEIDA, Cristóvão Domingos de; GUINDANI, Joel Felipe. Pesquisa documental: pistas teóricas e metodológicas. Revista Brasileira de História e Ciências Sociais, São Leopoldo, RS, Ano 1, n.1, Jul., 2009. Disponível em <https://periodicos.furg.br/rbhcs/article/view/10351>. Acesso em 14 mai. 2021.

SILVA, Kelanne Lima da, et al. Reflexões acerca do abuso de drogas e da violência na adolescência. Esc. Anna Nery 2010. Disponível em <https://www.scielo.br/j/ean/a/95Sb5h8K9zLzchZngSCDyTM/abstract/?lang=pt> . Acesso em 14 mai. 2021.

SILVA, Silvio Éder Dias da; PADILHA, Maria Itayra. O alcoolismo na história de vida de adolescentes: uma análise à luz das representações sociais. Texto Contexto Enferm [online]. 2013. Disponível em: <http://www.scielo.br/scielo.php?script=sci_arttext\&pid=S0104-07072013000300002\&Ing=en>. Acesso em 14 mai. 2021.

STASIAK, Adam. Harm reduction and content limitation: Social media plataforms' effects on fundamental human rights. Central European University. 2020. Disponível em <http://www.etd.ceu.edu/2020/stasiak_adam.pdf>. Acesso em 14 mai. 2021. 


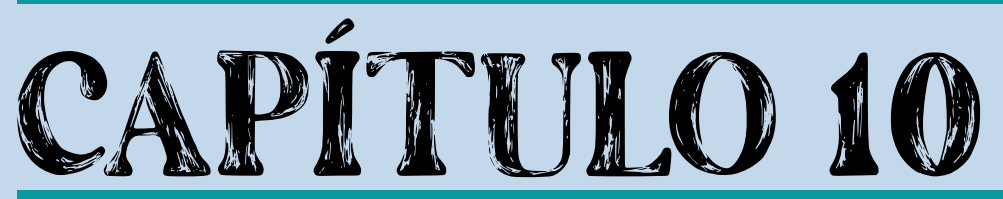

\section{SEX EDUCATION: IMPORTÂNCIA DA MÍDIA NA EDUCAÇÃO EM SAÚDE PARA SEXUALIDADE EM ADOLESCENTESS}

Eduarda Bertolini

Lavínia Comarú Traichel

Laysa Vitória Agostini 


\section{INTRODUÇÃO}

A sexualidade pode ser caracterizada como uma energia, contato, intimidade que se integra ao modo que nos sentimos, ações e interações com os outros, segundo a Organização Mundial da Saúde (OMS) (MELO, et al, 2011). Sabemos que na adolescência surgem muitas dúvidas sobre o corpo e sobre a sexualidade. Sabemos também que os pais e professores têm dificuldades para abordar a temática, deixando em aberto, muitas vezes, para que os adolescentes esclareçam suas dúvidas em fontes não confiáveis. Por isso é importante que existam movimentos de educação sexual com os adolescentes, para que a partir de fontes seguras possam se autoconhecer, tirar suas dúvidas e entender melhor tudo o que que engloba a sexualidade (CANO et al, 2000).

Dessa forma, práticas de educação em saúde com comunicação de igual para igual, com linguagem adequada para um entendimento adequado e ações que beneficiem a população em questão devem ser realizadas. Em meio a tanta evolução tecnológica e à facilidade que a juventude possui com os meios digitais, decidiu-se analisar como estas fontes podem auxiliar na propagação de informações e na educação sexual dos adolescentes.

Para isso, foi selecionada a série "Sex Education", transmitida na plataforma de streaming Netflix, para avaliar em como ela pode auxiliar nessa educação, citando temas de extrema importância com uma visão realista e natural. Nela são abordados temas como infecções sexualmente transmissíveis, aborto, descoberta da própria sexualidade, consentimento, assédio sexual, homofobia, relação abusiva, entre outros (SANTOS et al, 2020). Mostra uma perspectiva realista da curiosidade sexual adolescente e problemáticas da juventude, sendo uma fonte de educação sexual, de fácil acesso e com linguagem adequada para os adolescentes, evidenciando a importância das mídias como meio de propagar informações (SANTOS et al, 2020).

O enfoque do presente trabalho busca analisar como a série pode ter papel importante na integração da tecnologia com diversos temas, principalmente a 
educação sexual, que ainda tem muitos preconceitos envolvidos, tabus e questionamentos que não são sanados nem na escola nem em casa. Além disso, o modo como é passado facilita o entendimento e compreensão por parte dos alunos, tanto da escola tratada na série quanto para os jovens que a assistem, bem como pode funcionar como método de educação em saúde para os alunos de outras escolas e para auxiliar os pais a sanar as dúvidas de seus filhos em casa (SANTOS et al, 2020).

\section{METODOLOGIA}

Para a realização do presente trabalho, foi realizada uma análise de mídia cinematográfica, tendo como foco a série britânica Sex Education, criada por Laurie Nunn e lançada em 2019. Exibida pela plataforma de streaming Netflix, conta com três temporadas, totalizando 24 episódios. A trama se passa em uma escola de ensino médio de uma cidade inglesa, na qual uma dupla de estudantes, Otis e Maeve, observando a situação dos colegas em relação a sexualidade e relacionamentos, começa a oferecer serviços de orientação sexual e então, vários dilemas da vida de adolescentes vão sendo discutidos ao longo dos episódios.

A análise de mídia cinematográfica é caracterizada como uma pesquisa qualitativa com elementos de estudo de caso, que se baseia em elementos da mídia que podem ser usados na aprendizagem através da educação em saúde acerca da sexualidade em adolescentes. A pesquisa qualitativa trabalha com valores, crenças, hábitos, atitudes, representações, opiniões e adequa-se a aprofundar a complexidade de fatos e processos particulares e específicos a indivíduos e grupos (PAULILO, 1999), por isso a importância dessa análise para a realização.

Ademais, utilizou-se de levantamento bibliográfico nas bases de dados Scielo e Google Acadêmico, buscando assuntos como" importância do cinema na educação", "educação em saúde", "sexualidade e adolescentes" e "importância do diálogo sobre sexualidade com adolescentes". 


\section{EDUCAÇÃO EM SAÚDE}

A educação em saúde atua, na teoria e na prática, promovendo a saúde e prevenindo doenças, sempre de acordo com saberes científicos e as necessidades da população em questão. Essa prática visa tornar as pessoas ativas na transformação de sua vida e meio social, promovendo sua autonomia (FALKENBERG et al., 2014)

De acordo com o Ministério da Saúde, a educação em saúde pode se caracterizar como construção de conhecimento através da apropriação de conehcimentos pela população, com fim de ter projetos de saúde que se baseiam em suas reais necessidades. Assim, a educação em saúde é uma prática que opera na direção de engajar a população na preservação e manutenção da saúde, problematizando e reorientando práticas de saúde de modo a torná-las mais significativas e diversificadas (DARSIE; WEBER, 2021). São fundamentais, para tanto, profissionais de saúde, os gestores que apoiem esses profissionais e a população que vai moldar seus conhecimentos e aumentar sua autonomia nos cuidados, individual e coletivamente (ABREU, et al, 2013).

Complementarmente, o cinema, quando usado em escolas, é uma maneira de aproximar os alunos de suas realidades, o que permite maior facilidade na ocorrência das mediações escolares (BELLONI, 2005). Através do cinema, muitas realidades podem ser abordadas, e é interessante que o professor e demais profissionais envolvidos, encontrem meios de provocação para os alunos e iniciar as discussões que são necessárias (MORAN, 2007).

Assim, um trabalho com a série Sex Education em escolas, envolvendo alunos, professores, profissionais da saúde e até mesmo, os pais dos alunos, provocará os adolescentes a sanarem suas dúvidas e ajudará a expressarem seus medos, visto que muitos temas relacionados à sexualidade podem ser discutidos, de forma segura e confiável. Sabe-se que a sexualidade é um tabu para a sociedade, portanto, trazer esse tema de forma cinematográfica e descontraída 
pode oferecer benefícios para os adolescentes e familiares, em relação ao autoconhecimento e relacionamentos.

A sexualidade pode ser caracterizada como uma energia, contato, intimidade que se integra ao modo que nos sentimos, ações e interações com os outros, segundo a OMS. Sabemos que na adolescência surgem muitas dúvidas sobre o corpo e sobre a sexualidade, e sabemos também que os pais e professores têm dificuldade para abordar essa temática, deixando aberto, muitas vezes, para tirarem suas dúvidas em fontes não confiáveis. Nesse momento, entra a importância de existir uma educação sexual com os adolescentes, para que a partir de fontes seguras possam se autoconhecer, tirarem suas dúvidas e entenderem melhor tudo que engloba (CANO, et al, 2000).

Nesse sentido, é importante que hajam movimentos de educação em saúde, com comunicação de igual para igual, com linguagem adequada para um entendimento adequado e ações que beneficiem a população em questão. $\mathrm{Na}$ atualidade, com todos os avanços tecnológicos, as informações são divulgadas facilmente e existem muitas fontes para propagar conhecimento.

\section{CINEMA E EDUCAÇÃ̃O}

Rosália Duarte (2002), em seu livro “Cinema e Educação”, elucida que o espectador é um sujeito social que interage ativamente na construção dos sentidos que circulam nos filmes. Com isso, espectadores se identificam psicologicamente com aspectos, propriedades, atributos do outro, vivendo com os personagens as circunstancias dramáticas dispostas na narrativa fílmica (DUARTE, 2002, p. 7071). Segundo a autora,

[...] o contato com filmes produz, num primeiro momento, apenas imagos

- entendidos aqui como marcas, traços, impressões, sentimentos - significantes que serão lentamente significados depois, de acordo com os conhecimentos que o indivíduo possui de si próprio, da vida e, sobretudo, da linguagem audiovisual. O domínio progressivo que se adquire dessa linguagem, pela experiência com ela, associado a informações e saberes diversos significa e ressignifica indefinidamente as marcas deixadas em nós pelo contato com narrativas fílmicas (DUARTE, 2002, p. 74). 
A escritora também relata que a humanidade aprendeu, desde tempos imemoriais, que contar historias era uma boa maneira de transmitir conhecimento e ensinar valores aos mais jovens. Foi assim com as tragédias gregas, as parábolas bíblicas, os contos de fadas, as fabulas e as pantomimas medievais. (DUARTE, 2002, p. 63). Desta forma, o cinema também segue esta mesma linha, muitas vezes através de historias e exemplos traz consigo ensinamentos, ilustra situações reais, leva os seus espectadores à reflexão e pode ser um poderoso instrumento para a educação.

Neste cenário, diante do atual contexto tecnológico, com crescente ampliação do acesso aos meios digitais, o cinema foi se diversificando e nota-se um aumento no consumo de séries, sendo uma forma de mídia com crescente número de espectadores e grande popularização (SILVA, 2014). Sabe-se que as escolas têm muito privilégio com os estudos através do cinema, por que essa análise vai conectando com outras áreas do conhecimento, possibilitando várias perguntas (FABRIS, 2008, p. 130) e em virtude disso, as séries podem desempenhar um papel fundamental na educação, caracterizando-se como uma ferramenta dinâmica, atrativa e popular para disseminar conhecimentos (SILVA, 2014).

Por exemplo, a plataforma de streaming Netflix é amplamente disseminada e apresenta a série com título "Sex Education", na qual mostra uma perspectiva realista da curiosidade sexual adolescente e problemáticas da juventude, sendo uma fonte de educação sexual, de fácil acesso e com linguagem adequada para os adolescentes, evidenciando a importância das mídias como meio de propagar informações (SANTOS, et al, 2020).

\section{SEX EDUCATION COMO FERRAMENTA DE EDUCAÇÃO EM SAÚDE}

A série analisada aborda, com linguagem simples e com exemplos de situações reais vivenciadas pelos personagens, temáticas muito relevantes à sexualidade dos adolescentes, como infecções sexualmente transmissíveis (IST), 
disfunção sexual, aborto, identidade sexual, descoberta da própria sexualidade, consentimento, assédio sexual, homofobia, relações abusivas e exposição online.

Um dos personagens, Otis Milburn, é filho de uma terapeuta sexual e diante da convivência e educação que recebeu da mãe, acaba compartilhando conhecimentos e tendo respostas para muitos dos questionamentos de seus colegas de escola. Mesmo com problemas pessoais nessas questões, ele junta-se com sua amiga e abrem uma "clínica" de saúde sexual informal na escola, tirando dúvidas numa posição de igual para igual, sem preconceito, vergonha ou quaisquer julgamentos (SANTOS, et al, 2020).

Além disso, o seriado aborda também, de forma mais crítica, que as escolas, os professores e os pais são, muitas vezes, incapazes de fornecer a informação acerca da educação sexual de forma condizente com o que os adolescentes precisam para sanar suas dúvidas e para que não se sintam retraídos. Com isso, a série pode ter como foco de ensino também os pais e professores, ao mostrar de maneira mais clara como este assunto pode ser abordado, não tratando-o como um tabu, encarando como um processo natural do desenvolvimento dos jovens, e não mascarando o processo da descoberta sexual (SANTOS, et al, 2020).

Um acontecimento marcante na série, que expõe a necessidade de uma educação sexual que ensine sobre infecções sexualmente transmissíveis, é o "surto de clamídia" que os estudantes acreditam estar enfrentando, sem conhecimento da transmissão, sintomas, prevenção e consequências da doença. Nessa questão, uma das estudantes da escola perguntou para Otis sobre a necessidade de lavar a região genital com alvejante para acabar com a doença, refletindo a falta de conhecimento sobre saúde e sexualidade.

Outra cena que ilustra o receio, pressão e insegurança que muitos jovens enfrentam com a iniciação sexual está na fala da personagem Lily, no décimo episódio da série: 
Eu não sei. Acho que eu sinto que, se eu não fizer, vou me formar sem ter transado, então irei para a faculdade e estarei atrás de todos, e ninguém vai transar comigo porque serei a virgem estranha. E jamais transarei, porque serei encabulada, estranha e virgem. [...] Eu só não quero ficar para trás. Quero dar um fim nisso. (SEX EDUCATION, 2019)

Nesta situação, Otis teve papel fundamental ao acalmar a jovem diante de seus medos e ansiedade, explanando em uma conversa de igual para igual, que cada um tem seu tempo, bem como sobre a importância de não se comparar aos outros, não devendo sentir-se pressionada a realizar algo que ainda não está pronta.

Outro tema de grande importância e que precisa ser esclarecido é o assédio sexual. $O$ assunto é mostrado na série a partir do caso de uma menina que nega o corrido após sofrer assédio sexual no ônibus a caminho da escola. Ela acredita que se não pensar ou falar sobre o ocorrido, não sofrerá. Porém, a educação sexual poderia servir como ferramenta para discutir violência, sexualidade e relações de gênero. Assim, a série pode ser utilizada como um instrumento importante de educação em saúde voltado aos jovens, por abordar informações com os exemplos de educação em saúde que ocorrem entre os personagens, além de estimular o conhecimento e tirar as dúvidas existentes.

Somado a isso, a série pode ser utilizada em um outro momento, com pais e profissionais da saúde, para a elucidação desses a respeito dos anseios e necessidades específicas que estão em torno da sexualidade na adolescência, para que assim, possam ter um diálogo mais compreensível. Muitas cenas mostram diálogos esclarecedores entre Otis e sua mãe, a Dra. Jean Milburn, expondo a importância de uma boa relação de confiança entre pais e filhos para aconseIhamentos e esclarecimento de dúvidas.

\section{CONSIDERAÇÕES FINAIS}

A série tem papel muito importante no processo de educação sexual dos jovens, com a abordagem de temas fundamentais para o autoconhecimento. utilizando a linguagem acessível, abordagem realista e com responsabilidade, e 
falando de problemáticas tão importantes, reais e muitas vezes pouco discutidas em sala de aula e no ambiente familiar (SANTOS, et al, 2020).

Diante disso, é notável a importância que o cinema e, mais especificamente as séries, podem desempenhar no processo educativo dos jovens, caracterizando-se como um meio lúdico, atrativo e cada vez mais presente na realidade dos adolescentes. Portanto, após a análise da série "Sex Education", inferimos sobre a possibilidade e benefícios de ser utilizada como um instrumento auxiliar para a educação em saúde aos jovens (SANTOS, 2020) sendo importante o uso das mídias em sala de aula como fins educativos (NAPOLITANO, 2003), (CARMO, 2003), podendo ser utilizada em projetos de escolas juntamente com profissionais da área da saúde, e como método educativo entre os pais e os adolescentes, utilizando os momentos de educação em saúde que ocorrem entre os personagens da série e estimulando os adolescentes para que esclareçam suas dúvidas.

\section{REFERENCIAS}

ABREU, J. V.; GUEDINE, C. R. C.; MOREIRA, P. V. L.; LINS, T. S. Educação em saúde: relato de experiência com pré-escolares. Nutrire: rev. Soc. Bras. Alim. Nutr.= J. Brazilian Soc. Food Nutr., São Paulo, SP, v. 38, n. 1, p. 38-45, abr. 2013.

BELLONI, M. L. O que é mídia-educação. Campinas, SP: Autores Associados, 2005.

CANO, Maria Aparecida Tedeschi; FERRIANI, Maria das Graças Carvalho; GOMES, Romeu. Sexualidade na adolescência: um estudo bibliográfico. Revista Latino-Americana de Enfermagem, [S.L.], v. 8, n. 2, p. 18-24, abr. 2000. FapUNIFESP (SciELO).

CARMO, Leonardo. O cinema do feitiço contra o feiticeiro. Revista Iberoamericana de Educação, Canoas, n. 32, p. 71-94, 2003.

DARSIE, C.; WEBER, D. L. Geografia da Saúde e Educação Básica: um panorama. In: Robson Olivino Paim; Ana Maria de Oliveira Pereira; Carina Copatti, Claudionei Lucimar Gengnagel. (Org.). Geografias que fazemos: educação geográfica em diferentes contextos (Coleção: Percursos de educação geográfica). 1ed.Curitiba-PR: Editora CRV, 2021, v. 2, p. 189-198. 
DUARTE, R. Cinema e Educação. Belo Horizonte: Autêntica, 2002.

FALKENBERG, M. B. et al. Educação em Saúde e Educação na Saúde: Conceitos e Implicações Para a Saúde Coletiva. Ciência \& Saúde Coletiva, v. 19, n. 3, 2014. Disponível em: https://www.scielo.br/j/csc/a/kCNFQy5zkw4k6ZT9C3VntD$\mathrm{m} /$ ?lang=pt. Acesso em

15/10/2021.

MELO, S. M. M., Pocovi, R. M. S., Carvalho, G. D., Mendes, P. O. S. P., Santos, V. M. M. Educação e sexualidade. Florianópolis: UDESC/CEAD/UAB, 2011

MORAN, J. Ensino e aprendizagem inovadores com tecnologias audiovisuais telemáticas. In: MORAN, J; MASETTO, M; BEHRENS, M. Novas tecnologias e mediação pedagógica Campinas, SP: Papirus, 2000.

NAPOLITANO, Marcos. Como usar o cinema na sala de aula. São Paulo: Contexto, 2003.

FABRIS, E. H.. Cinema e Educação: um caminho metodológico. Educação e Realidade, Porto Alegre, v. 33, n. 1, p. 117-134, jan./jun. 2008.

PAULILO, M. A. S. A Pesquisa Qualitativa e a História de Vida. Serviço Social em Revista, Londrina, v. 2, n. 2, p.135-148, jul./dez. 1999.

SANTOS, L. G. T, et al.. Sex education: uma análise sobre a importância da mídia para educação sexual. Anais VII CONEDU - Edição Online, Campina Grande: Realize Editora, 2020. Disponível em: https://editorarealize.com.br/artigo/visualizar/69547. Acesso em 14/06/2021.

SILVA, M. V. B. Cultura das séries: forma, contexto e consumo de ficção seriada na contemporaneidade. Galaxia (São Paulo, Online), n. 27, p. 241-252, jun. 2014.

XAVIER, J.J.S, et al. Cinema: ferramenta pedagógica e humanista. A experiência do CineSocial, Ribeirão Preto, 2011 


\section{SOBRE OS ORGANIZADORES}

\section{CAMIIO DARSIE}

Professor Permanente do Programa de Pós-graduação em Educação, na Linha de Pesquisa Educação, Cultura e Produção de Sujeitos, da Universidade de Santa Cruz do Sul - UNISC. Coordenador do Internato de Saúde Coletiva e Professor no curso de Medicina. Vice-líder do Grupo de Pesquisa sobre Políticas Públicas, Inclusão e Produção de Sujeitos (PPIPS) e Editor-gerente da Revista Reflexão e Ação, do PPGEdu, na mesma instituição. Doutor em Educação pela Universidade Federal do Rio Grande do Sul, com Doutorado Sanduíche na Universidade de Minnesota (EUA), concluiu Pósdoutorado em Saúde Coletiva na Universidade Federal do Rio Grande do Sul, tendo desempenhado atividades de campo na Costa Rica, por meio da Universidad de Costa Rica (UCR). Atualmente, desenvolve atividades de pós-doutoramento em Educação, junto à Universidade Federal do Rio Grande do Sul, em pesquisa desenvolvida com a COVID Health Literacy Network. Desenvolve pesquisas nas áreas de Educação, Saúde e Geografia.

\section{BETINA MILLESHEIM}

Possui graduação em Psicologia pela Pontifícia Universidade Católica do Rio Grande do Sul (1989), mestrado em Psicologia Social e da Personalidade pela Pontificia Universidade Católica do Rio Grande do Sul (2001) e doutorado em Psicologia pela Pontifícia Universidade Católica do Rio Grande do Sul (2006). Membro do comitê assessor da Fapergs, nas áreas de Educação e Psicologia (2013-2014, 2015-2016). Professora adjunta e pesquisadora do departamento de Psicologia e do Programa de Pós-Graduação (Mestrado e Doutorado) em Educação da Universidade de Santa Cruz do Sul. Professora do Mestrado Profissional de Psicologia (UNISC). Coordenadora adjunta do Mestrado Profissional de Psicologia (gestão 2020-2021). Membro do GT "Territorialidades, violências, políticas e subjetividades" da Associação Nacional de Pesquisa e Pós-Graduação em Psicologia (ANPEPP). Atua principalmente nos seguintes temas: políticas públicas, inclusão, território, nomadismo, infância, literatura infantil. Líder do grupo de pesquisa "Políticas públicas, inclusão e produção de sujeitos" (PPIPS). ORCID: 0000-0001-9486-5459 


\section{VERA ELENEI DA COSTA SOMAVILIA}

Professora adjunta do Departamento de Ciências da Saúde Da Universidade de Santa Cruz do Sul - UNISC. Doutora em Educação pela Universidade Federal do Rio Grande do Sul (UFRGS). Possui mestrado em Desenvolvimento Regional pela UNISC, graduação em Enfermagem e Obstetrícia e Licenciatura em Enfermagem pela Faculdade de Enfermagem Nossa Senhora Medianeira (1994). Atua como docente nos cursos de Graduação em Enfermagem, Medicina e no Programa de Mestrado em Psicologia na Universidade de Santa Cruz do Sul, Coordenadora Técnica da área de Enfermagem do Serviço Integrado de Saúde - SIS. Com experiência na área de Saúde Pública e Saúde da Mulher. Membro integrante do Grupo de Estudos e Pesquisas em Saúde (GEPS) e Faz parte do grupo de pesquisa Identidade e Diferença na Educação UNISC. Atuou como pesquisadora em parceria com a Universitat Rovira I Virgili Facultat D'Infermeria (campos de Tortosa Catalunha - Espanha)UNISC. Desenvolve a pesquisa - A crise como potência para prospeção de ações na atenção básica em tempos de COVID 19. 


\section{SOBRE AS AUTORAS E OS AUTORES}

\section{Arthur Gomes Ribeiro}

Estudante de Medicina na UNISC - Universidade de Santa Cruz do Sul.

E-mail: arthurgribeiro15@gmail.com

Lattes: http://lattes.cnpq.br/4376426214729892

\section{Anna Lya Assmann da Motta}

Estudante de Medicina na UNISC - Universidade de Santa Cruz do Sul.

E-mail: assmannanna@gmail.com

\section{Ana Paula Backes}

Estudante de Medicina na UNISC - Universidade de Santa Cruz do Sul. E-mail: apbackes@mx2.unisc.br

\section{Amanda Hillesheim Schuck}

Estudante de Medicina da Universidade de Caxias do Sul (UCS).

E-mail: ahschuck@ucs.br

\section{Bruna Vendruscollo Rodrigues}

Estudante de Medicina da Universidade de Santa Cruz do Sul UNISC).

Email: brunavenr@gmail.com.

\section{Bruna Mallmann Specht}

Estudante de Medicina na UNISC - Universidade de Santa Cruz do Sul. E-mail: brunaspecht@hotmail.com

Lattes: http://lattes.cnpq.br/9308852704450474

\section{Barbara Taynara Michielin}

Estudante de Medicina na UNISC - Universidade de Santa Cruz do Sul. E-mail: barbaratmichielin@gmail.com

Lattes: http://lattes.cnpq.br/7352115322379907 


\section{Bianca Bortolini}

Estudante de Medicina da Universidade de Santa Cruz do Sul, UNISC.

E-mail: biancabortolini@mx2.unisc.br

\section{Bruna Luísa Küster}

Estudante de Medicina da Universidade de Santa Cruz do Sul UNISC).

\section{Bernardo Duarte Tomazi}

Estudante de Medicina, Universidade de Santa Cruz do Sul (UNISC).

E-mail: bernardoduartetomazi@gmail.com

\section{Camila Rabuske Limberger}

Estudante de Medicina da Universidade de Santa Cruz do Sul, UNISC.

E-mail: camilalimberger@mx2.unisc.br

\section{Carolina Tisott Burtet}

Estudante de Medicina, Universidade de Caxias do Sul (UCS).

E-mail: ctburtet@ucs.br

\section{Carolina Loebens Hinterholz}

Estudante de Medicina na UNISC - Universidade de Santa Cruz do Sul.

E-mail: carolhinterholz@hotmail.com

\section{Catiane Kelly Schaefer}

Estudante de Medicina na UNISC - Universidade de Santa Cruz do Sul.

E-mail: catianeschaefer@gmail.com

\section{Camilo Darsie}

Doutor em Educação, Vice líder do Grupo Pesquisa Políticas Públicas, Inclusão e Produção de Sujeitos (PPIPS) da UNISC - Universidade de Santa Cruz do Sul.

E-mail: camilodarsie@unisc.br

\section{Eduarda Rebés Müller}

Estudante de Medicina na UNISC - Universidade de Santa Cruz do Sul.

E-mail: eduarda.rebes98@gmail.com

Lattes: http://lattes.cnpq.br/1802199903232766 


\section{Eduarda Bertolini}

Estudante de Medicina da Universidade de Santa Cruz do Sul (UNISC)

Lattes: http://lattes.cnpq.br/6238308743693569

\section{Felipe Santos Silveira}

Estudante de Medicina na UNISC - Universidade de Santa Cruz do Sul. E-mail: felipessilveira27@gmail.com

\section{Felipe Bernadon}

Estudante de Medicina do $5^{\circ}$ semestre da Universidade de Santa Cruz do Sul, bolsista PUIC voluntário sob orientação do professor Camilo Darsie, docente do Curso de Medicina.

E-mail: felipebernardon@mx2.unisc.br.

\section{Fernanda Wartchow Schuck}

Estudante de Medicina na UNISC - Universidade de Santa Cruz do Sul.

E-mail: fewartchow@hotmail.com

\section{Fabiana Rafaela Santos de Mello}

Estudante de Medicina da Universidade de Santa Cruz do Sul (UNISC). E-mail: fmello@mx2.unisc.br

\section{Gabriel Delai de Freitas}

Estudante de Medicina da Universidade de Santa Cruz do Sul UNISC). Email: viniciusro@mx2.unisc.br

\section{Giovana Maria Fontana Weber}

Estudante de Medicina na UNISC - Universidade de Santa Cruz do Sul. E-mail: giovanamfweber@gmail.com

\section{Henrique Ziembowicz}

Estudante de Medicina na UNISC - Universidade de Santa Cruz do Sul. Membro integrante do Grupo de Estudos e Pesquisas em Saúde (GEPS) na UNISC. Universidade de Santa Cruz do Sul.

E-mail:henriqueziembowicz@gmail.com

Lattes: http://lattes.cnpq.br/1339705858054606 


\section{Isadora Fussiger Theissen}

Estudante de Medicina na UNISC - Universidade de Santa Cruz do Sul.

E-mail: isatheissen96@gmail.com

Lattes: http://lattes.cnpq.br/3410646167020440

\section{Iagro Cesar de Almeida}

Estudante de Medicina da Universidade de Santa Cruz do Sul (UNISC).

E-mail: iagro@mx2.unisc.br

\section{Jorgana Vargas Peruzzo}

Estudante de Medicina na UNISC - Universidade de Santa Cruz do Sul.

E-mail: jordanaperuzzo68@gmail.com

Lattes: http://lattes.cnpq.br/2064988450416027

\section{Jordana Carolina Weiss}

Estudante de Medicina da Universidade de Santa Cruz do Sul (UNISC).

E-mail: joordanacw08@gmail.com

\section{João Pedro Barros Carús}

Estudante de Medicina da Universidade de Santa Cruz do Sul, UNISC.

E-mail: carus@mx2.unisc.br

\section{Jonathas Gauciniski}

Estudante de Comunicação Social pela Universidade de Santa Cruz do Sul, acadêmico do curso de Medicina da Universidade de Santa Cruz do Sul - UNISC.

E-mail: jogauciniski@gmail.com

\section{Jéssica Fortunato Oliveira}

Estudante de Medicina da Universidade de Santa Cruz do Sul UNISC).

Email jessicafoliveira97@gmail.com

\section{Lucas Fernandes Mein}

Estudante de Medicina da Universidade de Santa Cruz do Sul - UNISC. E-mail: lucasmein1@hotmail.com

Lattes: http://lattes.cnpq.br/4357735238080397 


\section{Leonardo Teixeira Gomes}

Estudante de Medicina da Universidade de Santa Cruz do Sul - UNISC.

E-mail: leonardotgomes2@hotmail.com

\section{Laura Paveglio Schmidt}

Estudante de Medicina na UNISC - Universidade de Santa Cruz do Sul.

E-mail: paveglio.lau@gmail.com

\section{Letícia Sehn da Fonseca}

Estudante de Medicina da Universidade de Santa Cruz do Sul (UNISC). Email: leticiafonseca@mx2.unisc.br

\section{Luiza Dalla Vecchia}

Estudante de Medicina na UNISC - Universidade de Santa Cruz do Sul.

Email: lu_torriani@hotmail.com

\section{Larissa de Camargo Subtil}

Bacharel em Biomedicina e estudante, em graduação, do curso de Medicina na UNISC - Universidade de Santa Cruz do Sul.

E-mail: larissacsubtil@gmail.com

Lattes: http://lattes.cnpq.br/1841205257365162

\section{Laura Schmidt Rizzi}

Estudante de Medicina na UNISC - Universidade de Santa Cruz do Sul. E-mail: lauraschmidt.rizzi@gmail.com

Lattes: http://lattes.cnpq.br/0657279883530139

\section{Laysa Vitória Agostini}

Estudante de Medicina da Universidade de Santa Cruz do Sul (UNISC)

\section{Lavínia Comarú Traichel}

Estudante de Medicina da Universidade de Santa Cruz do Sul (UNISC) Lattes: http://lattes.cnpq.br/5484376909104211

\section{Martina Silveira Raineski}

Estudante de Medicina do $4^{\circ}$ semestre da Universidade de Santa Cruz do Sul. E-mail: martina.raineski@gmail.com 


\section{Mariana Wallauer Reinheimer}

Estudante de Medicina na UNISC - Universidade de Santa Cruz do Sul.

E-mail: marianareinheimer@mx2.unisc.br

\section{Marina Cervo Pinheiro Machado}

Estudante de Medicina na UNISC - Universidade de Santa Cruz do Sul.

E-mail: marinacpm8@hotmail.com

\section{Maria Eduarda Ferreira Zanin}

Estudante de Medicina na UNISC - Universidade de Santa Cruz do Sul.

E-mail: duda.zanin@hotmail.com

\section{Silvana Born Behling}

Estudante de Medicina da Universidade de Santa Cruz do Sul (UNISC).

E-mail: silvanabb1@hotmail.com

\section{Tiago Jairo Colling}

Estudante de Medicina do $4^{\circ}$ semestre da Universidade de Santa Cruz do Sul, bolsista PUIC voluntário sob orientação do professor Camilo Darsie, docente do Curso de Medicina.

E-mail: tiagocoll754@gmail.com.

\section{Thais Fernanda Baier}

Estudante de Medicina da Universidade de Santa Cruz do Sul (UNISC).

E-mail: tbaier@mx2.unisc.br

\section{Tomaz Mazuco Rodriguez}

Estudante de Medicina da Universidade de Santa Cruz do Sul - UNISC.

E-mail: tmrodriguez@mx2.unisc.br

\section{Vinicius do Nascimento Rodrigues}

Estudante de Medicina na UNISC - Universidade de Santa Cruz do Sul.

E-mail: viininr@gmail.com

Lattes: http://lattes.cnpq.br/8488217420113610 
www.arcoeditores.com

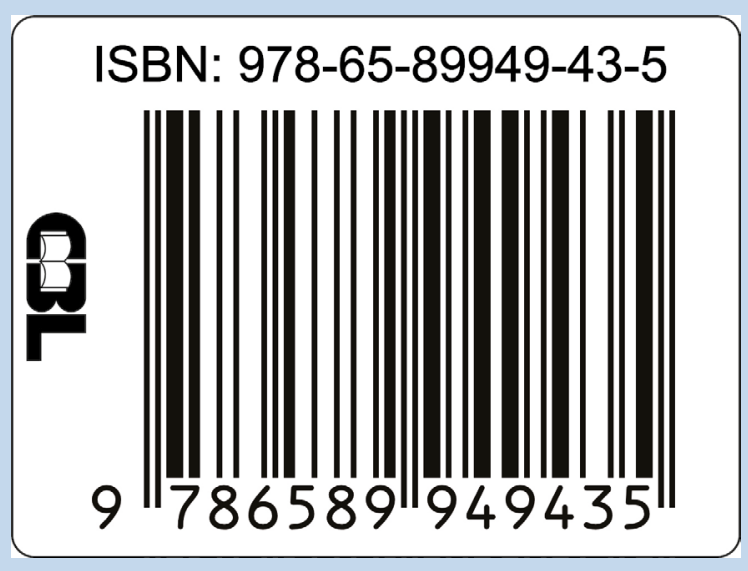

$$
\text { A. R्र } \mathrm{R} \text { C? }
$$

